\title{
Hurdles to Cardioprotection in the Critically Ill
}

\author{
Louise E See Hoe ${ }^{1,2, t, *}$, Nicole Bartnikowski ${ }^{1,3, \dagger}$, Matthew A Wells ${ }^{1,4}$, Jacky Y Suen ${ }^{1,2}$ and \\ John F Fraser ${ }^{1,2}$ \\ 1 Critical Care Research Group, The Prince Charles Hospital, Chermside 4032, Australia \\ 2 Faculty of Medicine, University of Queensland, Chermside 4032, Australia \\ 3 Science and Engineering Faculty, Queensland University of Technology, Chermside 4032, Australia \\ 4 School of Medical Science, Griffith University, Southport 4222, Australia \\ * Correspondence: 1.seehoe@uq.edu.au \\ + These authors contributed equally to this work.
}

Received: 5 July 2019; Accepted: 3 August 2019; Published: 5 August 2019

\begin{abstract}
Cardiovascular disease is the largest contributor to worldwide mortality, and the deleterious impact of heart failure (HF) is projected to grow exponentially in the future. As heart transplantation (HTx) is the only effective treatment for end-stage HF, development of mechanical circulatory support (MCS) technology has unveiled additional therapeutic options for refractory cardiac disease. Unfortunately, despite both MCS and HTx being quintessential treatments for significant cardiac impairment, associated morbidity and mortality remain high. MCS technology continues to evolve, but is associated with numerous disturbances to cardiac function (e.g., oxidative damage, arrhythmias). Following MCS intervention, HTx is frequently the destination option for survival of critically ill cardiac patients. While effective, donor hearts are scarce, thus limiting HTx to few qualifying patients, and HTx remains correlated with substantial post-HTx complications. While MCS and HTx are vital to survival of critically ill cardiac patients, cardioprotective strategies to improve outcomes from these treatments are highly desirable. Accordingly, this review summarizes the current status of MCS and HTx in the clinic, and the associated cardiac complications inherent to these treatments. Furthermore, we detail current research being undertaken to improve cardiac outcomes following MCS/HTx, and important considerations for reducing the significant morbidity and mortality associated with these necessary treatment strategies.
\end{abstract}

Keywords: heart failure; heart transplantation; mechanical circulatory support; cardioprotection

\section{Introduction}

Cardiovascular disease (CVD) accounts for approximately one third of total global deaths, is the primary cause of death in people aged $>15$ years old, and is heavily impacted by global population growth and ageing [1]. Heart failure (HF) affects over 26 million people globally [2]. In the US, it is projected that by 2030, HF prevalence will have almost doubled since 2013, and is estimated to reach $\sim \$ 70$ billion in healthcare costs $[3,4]$. The 20th century gave rise to extensive developments in diagnostics, mechanical circulatory support (MCS) technology, pharmacotherapeutics, and strategies aimed at delaying or reversing cardiac injury in various planned and unplanned circumstances [5]. Survival from HF continues to improve in response to effective treatments for HF risk factors, pharmacological approaches (e.g., $\beta$-blockers, angiotensin-converting enzyme inhibitors, statins), and percutaneous coronary interventions. However, this trend is not equal across all demographics [6].

Hospitalization following HF diagnosis is common, with one study reporting that $43 \%$ of patients were hospitalized four times following diagnosis [7]. Indeed, HF is the primary cause for hospital admission in those aged $>65$ years (US) [8]. Following hospitalization, the causes of death from HF or rehospitalisation vary significantly. For end-stage or refractory HF, there is no cure, and 
heart transplantation (HTx) is the final option available to clinicians. Depending on the country and respective regulations, critically ill cardiac patients may be amenable to differing forms of MCS, allowing time for treating physicians to make a decision, recovery of the heart prior to further extensive intervention, or as a destination therapy. The common forms of MCS include ventricular assist devices (VADs) and extracorporeal membrane oxygenation (ECMO).

The chronically ill cardiac patient has likely experienced accidental or sudden (e.g., Non-surgical ischemia or acute myocardial infarction) or surgical ischemia (e.g., cardiopulmonary bypass) as a result of cardiac complications, thus exposing them to ischemia-reperfusion injury (IRI). The pathophysiological mechanisms of IRI have been extensively detailed and reviewed elsewhere [9-11]. Due to the persistent and increasing burden of CVD, cardioprotective strategies aimed at limiting infarct size and IRI perturbations have been intensely investigated for almost 50 years. The NHLBI Working Group on the Translation of Therapies for Protecting the Heart from Ischemia stated in 2004 that 'three decades after its birth, the protection of the myocardium in the setting of AMI remains an unfulfilled promise' [12]. We are approaching 50 years since cardioprotective research began, and there is still no change $[13,14]$.

Several cardioprotective phenomena have been assessed extensively in various settings in both animals and humans. Brief intermittent episodes of myocardial ischemia-reperfusion (IR) either prior to or following a period of extended ischemia to limit infarct size are termed ischemic preand postconditioning, respectively. Initiating the repetitive cycles of brief IR in a remote organ or tissue to positively influence myocardial recovery from a sustained period of ischemia describes remote ischemic conditioning, which can be applied before, after or during the index ischemia. Ischemic pre-, post-, per-conditioning, and remote conditioning strategies initiate innate protective signaling mechanisms to improve post-ischemic myocardial recovery. Mechanistically, this generally involves activation of G-protein-coupled receptors (GPCRs) to initiate a cascade of pro-survival signaling pathways (typically Reperfusion Injury Salvage Kinase, RISK; or Survivor Activator Factor Enhancement, SAFE) that converge upon mitochondrial targets to preserve mitochondrial function, and promote the transcription of protective genes, thus reducing cellular injury [15-17]. Similar responses can be derived pharmacologically using ligands that activate these pathways or components thereof (e.g., adenosine, opioids) $[9,16,17]$. Numerous cardioprotective strategies have shown significant promise in small animal and preclinical studies, yet studies in human trials have all yielded generally poor outcomes. This failure in effective clinical translation has been attributed to shortfalls in design and conduct of both animal and clinical studies, with animal studies failing to account for relevant target cohort characteristics (e.g., comorbidities, medications, age, cardiovascular risk factors), and clinical trials facing issues with dosing and timing of the desired cardioprotective therapeutic, and appropriate patient selection $[13,14,16]$.

As the use of MCS technology continues to increase exponentially, in a health service that is crumbling under the increasing ageing population, it is naïve to believe this will not impact the incidence of refractory cardiac patients requiring treatment. Our research group has developed several preclinical models investigating MCS (ventricular assist devices, VADs) [18], extra-corporeal membrane oxygenation (ECMO) [19], and HTx [20]. These are important life-saving interventions used for patients with severe cardiac damage. While cardioprotection has traditionally referred to limiting the effects of IRI, in the context of this review, cardioprotection also refers to different strategies aiming to reduce the detrimental effects of cardiac surgical interventions (that may include IRI). Looking forward, this review will detail the important considerations for critically ill cardiac patients in the context of MCS and HTx for effective cardioprotection to be beneficial and effective in this cohort, and if research has unveiled any potentially effective therapeutics.

\section{Critically Ill Cardiac Patients}

End-stage HF is a progressive and complex clinical syndrome that results from impaired cardiac function to sufficiently meet physiological demands, leading to vascular congestion and tissue hypoperfusion [21,22]. Heart failure can develop following various cardiovascular disturbances 
such as AMI, myocarditis, metabolic syndrome, drug/alcohol abuse, arrhythmia, hypertension, cardiomyopathy [21-23]. Cardiac dysfunction is a hallmark of HF and the heart is exposed to extensive adverse remodeling that further exacerbates the myocardial impairment. However, the extensive cardiac dysfunction broadens to impair the systemic vasculature, with significant activation of neurohormonal and/or inflammation pathways, culminating in severe end-organ dysfunction (e.g., anemia, renal failure, cachexia, respiratory complications) $[22,24]$. Several recent studies have highlighted the profound molecular changes upon the vasculature following AMI, that could be important potentiating factors for the development of HF. Using tissue microarray, Kong and colleagues demonstrated that collagen III is reduced in the aortic wall extracellular matrix of AMI patients, and suggested this reduction may enhance plaque vulnerability, and thus the propensity for vessel occlusion and AMI [25]. Modification of membrane lipids is an important factor in the development of cellular injury, tolerance to ischemia and dependence of cardioprotective/cytoprotective signaling [26,27]. Indeed, unique lipid profiling of ceramides in plasma (but not aortic tissue) following AMI, have recently been demonstrated to predict long-term incidence of detrimental cardiac and cerebrovascular events [28]. The authors suggested that this risk signature profile is of myocardial origin following ischemia, not from the vasculature [28]. AMI also induces specific transcriptome patterns in vascular smooth muscle cells (VSMCs) from the aortic wall. Gene expression analysis of VSMCs identified upregulation of hypoxia signaling in the cardiovascular system [29] and cadherin superfamily members [30]. These molecular myocardial and systemic alterations associated with AMI may be important considerations for the development and subsequent management of HF patients.

\section{Mechanical Circulatory Support (MCS)}

The gold standard treatment of end-stage HF, heart transplantation (HTx), is limited by a lack of available donor organs. Consequently, MCS has become an important treatment strategy for severe acute and chronic HF [31,32]. The development of MCS systems have paralleled the expansion of HTx [32], and has continued to expand due to improved devices and clinical acceptance.

MCS provides an attractive treatment option when conventional medical therapies fail. However, widespread use is still inhibited due to technological limitations, inherent complications with MCS, and suboptimal clinical application [33]. The MCS systems discussed herein are focused on those that can aid/provide potential treatment strategies but can implement cardioprotective treatments, or have shown some clinical promise for long-term cardiac recovery, including extracorporeal membrane oxygenation (ECMO) and ventricular assist devices (VADs) (summarized in Figure 1). 


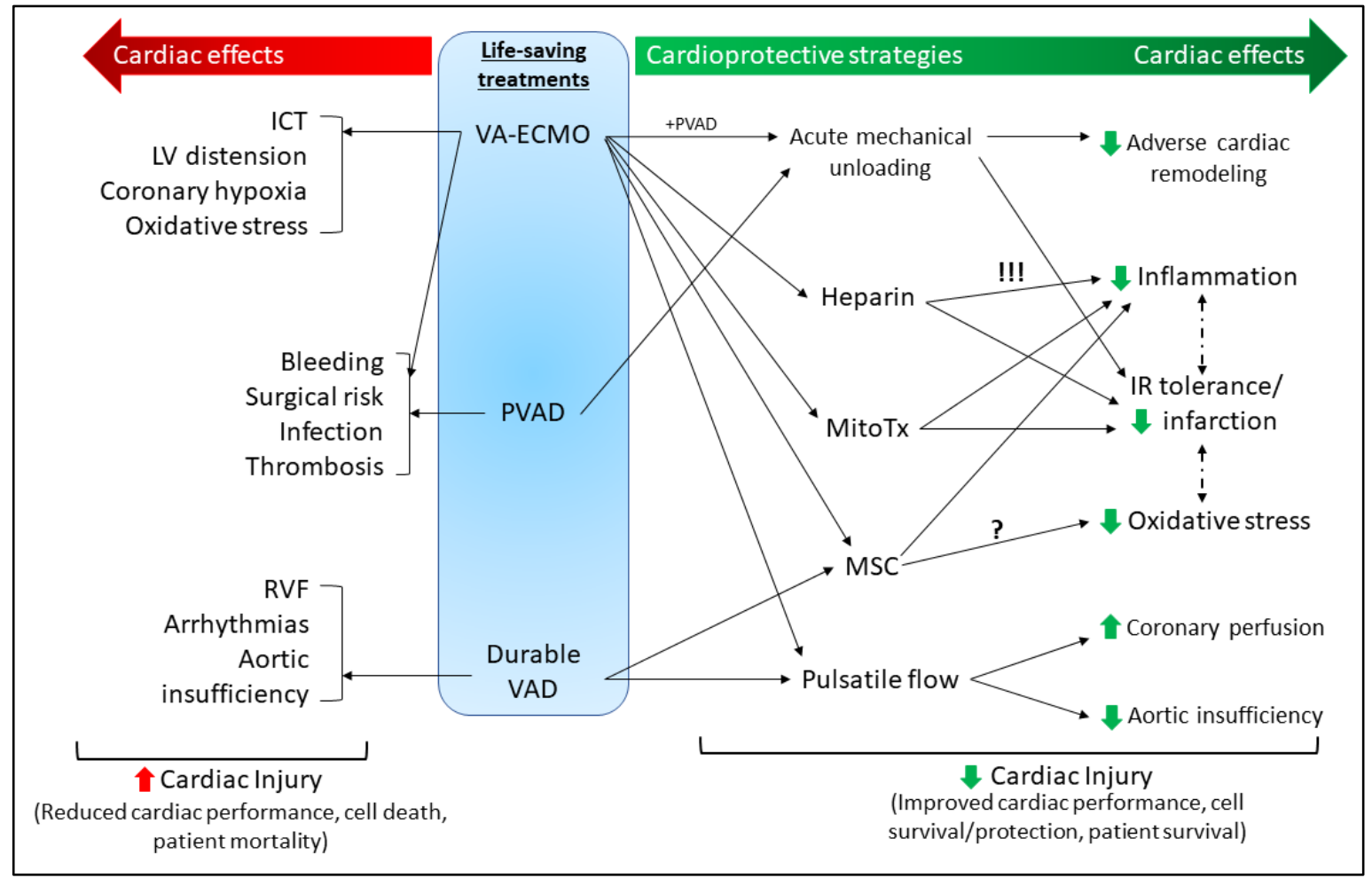

Figure 1. Summary of the current mechanical and molecular cardioprotective strategies associated with mechanical circulatory support MCS (discussed in Section 3). In the absence of effective conventional therapies for severe acute and chronic HF, the use of MCS (VA-ECMO, PVAD, durable VAD) can be a life-saving treatment for patients, but due to technical limitations and surgical risks, remains associated with a high risk of mortality (left side of figure in red). These MCS strategies can be used to provide a mechanical cardioprotective benefit (e.g., pulsatile flow, acute mechanical unloading); however, molecular cardioprotective strategies (e.g., MitoTx, MSC) are being investigated for use alongside these treatments to increase their cardiac benefit, reduce adverse side effects, and improve patient survival (right side of figure in green). Heparin is typically cardioprotective independently of its important anticoagulation role; however, in ECMO settings is associated with hemodynamic complications and limited patient survival (this risk is denoted by !!!). Additionally, while MSCs have demonstrated roles in limiting oxidative stress in various settings [34], this is yet to be delineated in settings of ECMO. VA-ECMO_venoarterial extracorporeal membrane oxygenation; PVAD—percutaneous ventricular assist device (VAD); ICT-intracardiac thrombosis; LV-left ventricular; RVF-right ventricle failure; MitoTx — mitochondrial transplant; MSC—-mesenchymal stem cells; IR—ischemia-reperfusion.

\subsection{Short-Term MCS}

Short-term MCS has evolved significantly as an effective method of acute support for patients with cardiogenic shock, which still has an extremely high mortality rate at 50\% [35-37]. Short-term MCS devices are used as either a bridge to myocardial recovery, long-term MCS or HTx, and can also be used to aid high-risk coronary interventions [38-40]. Recent technological advances have dramatically improved the efficacy of short-term MCS devices, leading to use in an earlier stage of $\mathrm{HF}$, in a broader number of patients. Options for short-term MCS that could further benefit patients by providing cardioprotective treatment include ECMO and percutaneous ventricular assist devices (PVADs), such as the TandemHeart ${ }^{\circledR}$ and Impella ${ }^{\circledR}$ systems [41].

\subsubsection{Extracorporeal Membrane Oxygenation (ECMO)}

ECMO is a modified form of the cardiopulmonary bypass device used to support patients in critical conditions with life-threatening respiratory failure or cardiogenic shock. Through the use of a 
continuous flow, centrifugal pump and a membrane oxygenator, ECMO drains deoxygenated, venous blood from the patient through a large cannula, externally reoxygenates blood in the oxygenator, and returns oxygenated blood via another cannula into the body. The choice of ECMO cannulation (type and size of cannula) significantly impacts cardiopulmonary function whilst on ECMO, and is an important consideration to achieve maximal hemodynamic support whilst limiting ECMO-associated complications (e.g., infection, bleeding, stroke, thrombosis). The resultant ECMO configuration (specific venous and arterial placement of cannulas throughout the body) provides temporary hemodynamic support, but must be considered dynamic, and ECMO cannulation strategies and configurations must evolve with the changing patient requirements to achieve optimal outcomes [42]. The technology has existed for $>40$ years and its use has seen significant growth over the last decade (2008: 2803 cases vs 2018: 10,423 cases) [43]. In particular, veno-arterial (V-A) ECMO has been used successfully for various cardiac diseases, including cardiogenic shock, myocarditis, acute coronary syndrome, cardiomyopathy, cardiac arrest refractory to usual resuscitative techniques, bridge to long-term MCS or HTx, primary graft failure, and secondary HTx rejection. Unfortunately, ECMO is associated with a high mortality $(40 \%-60 \%)[44,45]$. Most V-A ECMO research has been physiological in nature, examining the effects and potential benefits on patients, particularly those with cardiogenic shock. In contrast, few studies have examined the molecular and mechanistic basis of ECMO-associated adverse effects on patients.

\subsubsection{Percutaneous VADs}

PVADs have been very effective in treating patients with cardiogenic shock as a bridge to recovery, by improving the hemodynamic stability of the patient and increasing survival by reducing the risk of multisystem organ failure [46]. There has been substantial growth in the use of PVADs clinically, with a 30X increase in PVAD implants between 2007 and 2012 [44,45], coupled with a decrease in intra-aortic balloon pump (IABP) usage over the same time period. PVADs are able to provide robust hemodynamic support with a cardiac output up to $4-5 \mathrm{~L} \cdot \mathrm{min}^{-1}$, compared to IABPs which can only provide $0.5 \mathrm{~L} \cdot \mathrm{min}^{-1}$ of support $[36,44]$. Clinically available PVADs include the Impella ${ }^{\circledR}$ (Abiomed, Inc., Danvers, MA, USA) or the TandemHeart ${ }^{\circledR}$ (CardiacAssist, Inc., Pittsburgh, Pennsylvania).

The TandemHeart system consists of a $21 \mathrm{~F}$ venous transeptal inflow cannula, implanted through the femoral vein and right atrium, which withdraws oxygenated blood from the left atrium (LA) [47]. This is then pumped into the systemic circulation via a 17F femoral artery catheter using a continuous flow centrifugal blood pump and an arterial perfusion catheter [41], with a flow rate of $4 \mathrm{~L} \cdot \mathrm{min}^{-1}$. There have been two randomized clinical studies comparing the TandemHeart to IABP in patients with cardiogenic shock, secondary to acute myocardial infarction $[48,49]$. These studies demonstrated superior LV unloading and improved end-organ perfusion compared to the IABP. However, neither study reported a difference in 30-day mortality, with the use of larger insertion cannulas for the TandemHeart resulting in more bleeding and limb ischemia [49].

The Impella devices are catheter mounted continuous flow axial blood pumps which are placed across the aortic valve [46], with the inflow of the cannula within the left ventricle (LV) and the outflow pumping into the aorta. There are several versions of the Impella pump that differ in size, implantation method and output. The Impella $2.5(12 \mathrm{~F})$ is the most commonly used pump and along with the Impella CP (14F), this device is implanted percutaneously, with a $2.5 \mathrm{~L} \cdot \mathrm{min}^{-1}$ and $3 \mathrm{~L} \cdot \mathrm{min}^{-1}$ flow, respectively [41]. Due to the ease of implantation, the Impella 2.5 and $\mathrm{CP}$ are frequently used to support the heart during interventions such as revascularization and ablation [50]. The larger versions of this device, the Impella $5.0(21 \mathrm{~F})$ and LD (21F) both require surgical cutdown, but have a higher flow rate of $5 \mathrm{~L} \mathrm{~min}^{-1}$ [41]. Similarly to the TandemHeart clinical trials, Seyfarth et al. [51] reported in the ISAR-SHOCK trial comparing Impella 2.5 to IABP for patients with cardiogenic shock, that the Impella 2.5 provided superior hemodynamic support, however there was no difference in 30-day mortality. Similarly, retrospective analysis by Schrage et al. identified no improvement in 30-day mortality following Impella use in patients with AMI complicated by cardiogenic shock [52]. Both the TandemHeart and the Impella have been shown clinically to unload the LV while improving systemic 
blood flow, despite the different hemodynamic modes of these pumps $[49,51,53]$. Both of these PVADs offer strategic therapeutic options for mechanically unloading the heart, a recently evolving clinical cardioprotective strategy, while causing minimal complications compared to other MCS systems.

\subsubsection{Durable VADs}

Durable VADs are rotary blood pumps that have been developed to support the failing heart and restore blood flow to the body, by removing blood from the LV and returning it into the circulatory system via the aorta $[54,55]$. The size, durability and reliability of VADs have progressed substantially in the past decade, emerging as the main device for providing short to long-term support of a failing LV for patients awaiting HTx. However as these devices have evolved as a standard treatment for end-stage HF patients, VADs are now being used as a destination therapy for patients ineligible for HTx [56,57]. As a result, there has been a substantial increase in the number of VADs implanted in the last five years, with approximately $46 \%$ of all implants as a destination therapy. According to the USA's Interagency Registry for Mechanical Assisted Circulatory Support (INTERMACS) [58], there was an >25x increase in device implantations from 95 in 2006, to over 2500 in 2016.

VAD implantation has also been targeted toward bridge to myocardial recovery, with a limited number of patients thus far able to recover sufficient cardiac function to be weaned from the device [59]. By their design, VADs remove excess mechanical load on the heart, thereby allowing the heart to potentially recover some myocardial structure and function. A disconnect persists between biological recovery and improved clinical outcomes that require further investigation. According to the INTERMACS database, of patients who received VADs from 2006-2013, only $0.9 \%$ were bridged to recovery [60]. However, durable VADs may prove to be a more common therapeutic approach in the future with advancing technology, and with a large subset of patients reliant on these devices as a destination therapy [61].

The HeartMate II (Thoratec Corporation, Pleasanton, CA) is the most widely implanted VAD, with over 20,000 devices implanted worldwide [60]. It is an axial continuous flow pump that gained FDA approval for bridge to transplant (BTT) in 2008 and as a destination therapy in 2010. The next generation device, the HeartMate 3 , is a centrifugal continuous flow pump that includes a small artificial pulse. The MOMENTUM 3 trial demonstrated superiority in this pump compared with the HeartMate II device, with $77.9 \%$ of the HeartMate 3 patients surviving to 2 years post-implant without a disabling stroke, or need to replace the pump compared to only $56.4 \%$ of the HeartMate II patients [62]. The HeartMate 3 gained FDA approval as a BTT device in 2017 and as a destination therapy in 2018.

\subsection{MCS-Associated Complications}

While the development of MCS systems have revolutionized the care of HF and critically ill patients, they are prone to complications that limits the use of these devices clinically. This will inevitably impede their clinical application as a cardioprotective strategy until these complications can be mitigated.

\subsubsection{ECMO Complications}

ECMO has been associated with several systemic complications, including bleeding and thrombosis, infection, acute kidney injury, and neurologic complications and stroke [63-65]. There are also cardio-specific complications that are strongly associated with V-A ECMO, such as intracardiac thrombosis, coronary hypoxia, LV distention and oxidative stress, which will be the focus of the review herein. These complications along, with the high mortality rate associated with this treatment, are a significant barrier to increased use of ECMO and its implementation in the ICU as a cardioprotective strategy.

Cardiac Thrombosis - Intracardiac thrombosis (ICT) is a well-recognized complication for V-A ECMO. Though rare, it can be life-threatening and several case reports have highlighted the significant 
mortality associated with ICT on V-A ECMO [66,67]. Williams and Bernstein summarized 12 reported cases of ICT, where the primary indication for V-A ECMO was cardiogenic shock, secondary to myocardial infarction [68]. Heparin was used and reported in 8 of these cases. Of the 12 patients with ICT, only two patients survived. Similarly, Weber et al. retrospectively analyzed their femoral V-A ECMO patients between 2007 and 2015, and identified 11 patients (3.91\%) developed intra- or extra-cardiac thrombus [69]. In this study, approximately $50 \%$ of patients received V-A ECMO post-cardiotomy, while the other $50 \%$ were supported with V-A ECMO as extracorporeal cardiopulmonary resuscitation. All patients received heparin anticoagulation, with ACT (activated clotting time) and aPTT (activated thromboplastin time) monitoring. No patients survived in this cohort. Despite receiving anticoagulation (traditionally with intravenous unfractionated heparin), thrombosis continues to be a major issue for ECMO patients in general. Development of LV thrombosis is present in up to $40 \%$ of patients presenting with AMI and ventricular dysfunction, as decreased contractility of the ventricles greatly increased potential for intracavitary blood stasis. This is further exacerbated with the retrograde flow of V-A ECMO, which significantly increases afterload and impairs the ejection of blood from the LV, leading to closure of the aortic valve. Currently, minimal evidence exists to guide the best approach to treat V-A ECMO patients with ICT. Treatment modalities used for ICT management include surgical thrombectomy, local thrombolysis and use of VAD to ensure adequate forward flow of blood $[68,70]$.

Left ventricular distention- During V-A ECMO, the retrograde flow causes increased LV afterload and pressure in the aorta. This can lead to LV distension as the impaired LV is unable to generate sufficient power to overcome the increased afterload in order to eject blood. This causes progressive LV dysfunction, wall stress, pulmonary edema, and impairment of myocardial oxygenation [71,72]. In order to address these complications, a number of strategies to facilitate LV unloading are suggested. These include pharmacological approaches, inotropic support, IABP implantation, surgical LV venting, and Impella implantation [73].

Coronary Hypoxia - Oxygen saturation on V-A ECMO is usually normal (>90\%), as the upper body is provided with blood from LV that has been oxygenated by normally functioning lungs, while the lower body is supported by fully saturated blood from V-A ECMO [74]. However, in the event of patients with concomitant pulmonary dysfunction, blood ejected from the heart is no longer sufficiently oxygenated This deoxygenated blood preferentially supplies the coronary arteries, cerebral circulation and upper limbs, resulting in "dual circuits" and possible hypoxic injury (coronary and cerebral) $[75,76]$. This issue is well-supported by both preclinical studies and clinical cases, and most ECMO clinicians monitor for differential hypoxia $[76,77]$. Possible strategies to counteract this hypoxia include alternative cannulation strategy (V-AV ECMO) [76] and the recent development of pulsatile ECMO flow (to be discussed below).

Oxidation Damage - Continuous exposure of blood to a foreign surface occurs with MCS, particularly with ECMO, and not only leads to an inflammatory response [78], but coupled with the on-going hyperoxia from the unnaturally high concentration of oxygen [79], causes an oxidant stress response and oxidative damage [80]. Patients supported by ECMO are susceptible to reactive nitrogen and oxygen species (RNOS). Lipid peroxidation, oxidative protein and DNA damage are all possible adverse consequences, and these could lead to altered membrane fluidity, permeability and subsequently physiological changes such as ion gradients, ultimately forming a positive feedback loop leading to more RNOS. Cardiomyocyte membrane integrity is integral to proper cardiac function, stress resistance and mechanisms of cardioprotection [26,27]. However, membrane integrity is also adversely impacted by age, metabolic disorders and IRI [26,27]. Thus, exaggerated oxidative damage upon an already at-risk heart (and cardiomyocyte membrane) could significantly exacerbate cardiac injury beyond repair. Oxidative damage is also a significant problem for MCS in general, and is a major contributor to complications such as postoperative atrial fibrillation, acute kidney injury and acute lung injury after cardiac surgery. Ultimately, oxidative stress is a key factor to ECMO patient mortality and morbidity. 


\subsubsection{PVAD Complications}

Complications associated with the use of PVADs are relatively few compared with other MCS systems and primarily include bleeding, limb ischemia, cannula dislodgment, and infection [81]. The use of the Impella devices is contraindicated in patients who have heavily calcified aortic valves due to the risk of thromboembolism [82]. While the TandemHeart carries potential complications during implantation, particularly during transeptal puncture, with the risk of accidental puncture of the aortic root, coronary sinus and posterior free wall of the right atrium [81].

\subsubsection{Durable VAD Complications}

Despite the clinical benefit of LVADs, with the 1-year survival rate equaling that of HTx recipients ( $85 \%)$, significant complications occur with this treatment [83]. According to the INTERMACS registry, of 17,633 VAD implants, at least one adverse event occurred in up to $60 \%$ of patients by six months post-implantation, and in up to $80 \%$ by two years [58]. Major complications include bleeding, device thrombosis, infection, neurological complications (including strokes), renal impairment, and multi-organ failure [84]. Cardiac specific complications include cardiac arrhythmias, right ventricular (RV) failure and aortic insufficiency.

Ventricular Arrhythmias - Recurrent and frequent ventricular arrhythmias (VAs) are known to occur following LVAD implantation in up to $35 \%$ of patients $[85,86]$. They have been attributed to changes in repolarization of the ventricles due to acute LV unloading following LVAD implantation [87]. Additionally, VAs may also be caused by altered calcium handling due to the upregulation of sarcomeric and calcium handling genes, by mechanical irritation caused by the inflow cannula at the LV apex, or by lack of beta-adrenoceptor ( $\beta$-AR) antagonism use [86]. Oswald et al. demonstrated that VAs occurred more commonly in patients with nonischemic HF (50\%) compared to the incidence in ischemic HF patients (22\%) [88]. Management of VAs in VAD patients is approached by following appropriate pharmacological treatment including $\beta$-AR antagonists and other antiarrhythmic drugs, while there is no consensus regarding the placement of automatic implantable cardioverter defibrillators (AICD) [88]. While the current pharmaceutical treatment protocol is necessary to attenuate any VAs associated with VAD implantation, this could inhibit some cardioprotective strategies while using these devices (see Section 3).

Aortic Insufficiency - Long-term VAD support may lead to de novo aortic valve lesions, promoting commissural fusion, stenosis and aortic insufficiency (AI) [89], occurring in 10-40\% of patients [90]. The mechanisms of this complication is multifactorial. Previous clinical studies have shown that the development of AI has primarily been with the HeartMate II VAD suggesting that continuous flow physiology plays a partial role in the development of this complication [90]. The comparatively small diameter of the VAD outflow cannula in relation to the aorta, results in increased fluid velocities in the aorta, causing greater wall stress [91,92]. This in turn results in thinning of the aortic medial layer, causing aortic root dilation and AI. In addition to this, LVAD patients may not be able to generate sufficient systolic pressure to open the aortic valve, thus high-pressure and velocity jets of regurgitated blood volumes contacting the root side of a closed aortic valve may result in valvular damage and degeneration [90]. Pulsatile flow can combat this complication and protect the aortic valve. Therefore, artificial pulse generated by the VAD would be necessary to facilitate this. The only device clinically available that can generate a pulsatile flow rate is the HeartMate 3, however further investigation into the operation and management of this device would be required for this application.

Right Ventricular Failure - Right ventricular failure (RVF) is considered one of the most serious complications following left-VAD (LVAD) implantation and can occur in 9-49\% of LVAD recipients in the postoperative period $[93,94]$. LVAD function and blood flow relies heavily on right ventricular (RV) function, thus the occurrence of RVF leads to decreased tissue perfusion and multi-organ failure [95], which are associated with increased morbidity and mortality, and reduced survival to HTx [96]. The pathophysiology of RVF post-LVAD is not well understood and the development of RVF can occur for a variety of reasons. The function of an LVAD is to provide systemic blood circulatory support to 
augment the failing LV and restore normal cardiac output, however, this is greatly dependent on the appropriate filling of the LV by the RV. Following implantation, initiation of LVAD support begins by slowly increasing pump speed, which decompresses the LV and increases preload to the RV [97]. This exposes the RV to loading conditions similar to those provided by a normal functioning LV, leading to an increase in RV preload; an alteration of RV contractility, and an increase in RV afterload due to pulmonary vasoconstriction, all of which can lead to RVF with any existing RV impairment [96]. This sequence of events can lead to RVF, and can start intraoperatively or in the early postoperative period [98].

Furthermore, the LV and RV are interdependent, with any change in compliance, shape or size of one ventricle affecting the function of the other due to the interventricular septum, interlacing muscle fibres, and the pericardium [99]. In the context of LV unloading, leftward shift of the intraventricular septum may decrease septal contribution to RV contraction, leading to RVF. In a retrospective study of 76 patients receiving a continuous-flow LVAD, persistent leftward shift of the interventricular septum 30 days post-implantation was associated with significantly worse outcomes at 90 days [100]. Determining which patients are at highest risk of developing RVF after LVAD implantation is a challenging clinical problem. Early recognition of RV failure is key to improving outcomes in these patients independent of the treatment therapy (medical therapy, MCS for the RV, or both). In order to improve clinical outcomes, altered perioperative management strategies aimed at RV protection are required, however elucidation of the mechanisms causing this complication are required before this can be realized.

\subsection{Cardioprotective Strategies for MCS}

Cardioprotection as a field has largely centred around pharmacological treatment strategies and promoting innate protective responses aimed at preserving the function and viability of the heart following cardiac injury. However with the technological advances in MCS made in the past decade, the use of these devices to support the heart and circulatory system offer a new field of investigation into preserving cardiac function. Presented herein are potential strategies implementing MCS to preserve or improve cardiac function. Due to the nature and size of the devices, the majority of the research is physiological in nature, from either pre-clinical or clinical studies. As the field continues to expand, more mechanistic research is required to truly harness MCS as a cardioprotective strategy.

\subsubsection{Acute Mechanical Unloading}

Limiting myocardial infarct size and combating IRI, remain important targets of clinical treatment. This was clearly indicated by a recent study of $>2600$ patients showed that for every $5 \%$ increase in infarct scar size, the 1-year all-cause mortality increased by $19 \%$, and 1-year HF hospitalization increases by $20 \%[101,102]$, when treated for primary reperfusion. Acute mechanical unloading of the heart has recently gained momentum as a clinical treatment option following acute myocardial infarction (AMI) [53].

Acute mechanical unloading of the heart is a reduction in the mechanical power expenditure of the ventricle, by taking blood directly from the LV to the aorta while maintaining systemic and coronary perfusion pressure, known as LV-aortic pressure uncoupling. Clinically, this can be achieved by using a PVAD, which reduces the metabolic demands and physical forces on the heart. In the context of cardioprotection, particularly in the setting of AMI, this uncoupling of the LV from the systemic circulation aims to limit cardiac power expenditure, minimize myocardial oxygen consumption $\left(\mathrm{MVO}_{2}\right)$, protect against IRI, limit infarct size and reduce hemodynamic forces and ventricular wall stress that lead to ventricular remodeling $[102,103]$.

A number of pre-clinical studies have demonstrated the efficacy of acute mechanical unloading. Meyns et al. showed that LV support using a catheter-mounted axial flow pump led to reduced $\mathrm{MVO}_{2}$ during ischemia and reperfusion, and reduced infarct size that correlated with the degree of unloading during reperfusion [104]. Thus, more myocardial salvage can be achieved with more ventricular 
unloading. In a canine MI model, the timing of LV unloading significantly impacted mitochondrial function and integrity, with normal mitochondrial integrity and ultrastructure observed if LV unloading was applied prior to reperfusion. Conversely, LV unloading commenced after reperfusion, similarly to no support, increased contraction band necrosis, mitochondrial calcium deposition and mitochondrial swelling [105]. Furthermore, the results from these studies were confirmed by Tamareille et al. who demonstrated that infarct size was reduced by $54 \%$ with LV unloading in pigs, while simultaneously reducing endothelin-1 and calcium overload, both important mediators of reperfusion injury [106]. Kapur et al. confirmed that LV unloading reduced infarct size and induced release of RISK pathway mediators, SDF- $1 \alpha$ (cardioprotective cytokine) and antiapoptotic markers [53,107]. Further studies by this group identified increased expression of genes associated with mitochondrial integrity and cellular respiration and improved cardiac function 28 days following AMI, with limited expression of HF biomarkers [108].

Despite the positive pre-clinical studies in this area, the clinical application of acute mechanical unloading was limited technologically until the clinical introduction of PVADs. The Impella and TandemHeart can be implanted before or during other percutaneous coronary interventions (PCI), eliminating the need for multiple procedures to be performed on the patient. From the USpella registry, it was shown that early use of the Impella 2.5 to provide LV unloading and hemodynamic support prior to PCI was associated with more complete revascularization and higher in-hospital and 30-day survival of patients [109]. This was further confirmed in another registry study of 287 patients, also indicating improved survival to discharge over patients receiving late mechanical support [110]. However, prospective clinical studies, further coupling the clinical outcomes with the mechanisms behind acute mechanical unloading are still required.

Acute mechanical unloading can also be coupled with V-A ECMO in order to reduce the current complication of LV distension and decrease mortality in adult patients with cardiogenic shock [111]. This is achieved by simultaneously supporting a patient with either a PVAD or IABP while under V-A ECMO support, in order to unload the heart. The use of IABP to unload LV in V-A ECMO patients (135 cases) was reported in 2014 by Gass et al. to reduce the rate of complications and mortality [112]. Blade atrial septostomy or atrial septostomy, and placement of an LA venting cannula has also been described. In addition, catheter-based LV drainage (e.g., Impella) can be used to reduce LV distension [113]. In a retrospective analysis of 66 patients, ECMO+Impella (ECPELLA) showed significantly lower 30-day mortality than the ECMO group [114]. No other secondary outcomes were observed, except high inotrope usage with ECMO alone. Likewise, another retrospective study of 157 patients reported similar findings, where patients in the V-A ECMO and Impella group had significantly lower hospital mortality and a higher success rate of bridging to recovery or further therapy [115]. In addition, there is a current RCT studying the benefit of Impella with V-A ECMO for cardiogenic shock (REVERSE, NCT03431467). This study aims to investigate if the addition of direct ventricular unloading using Impella CP leads to higher rates of cardiac recovery, defined as survival free from MCS, HTx or inotropic support at 30 days. The study is expected to complete by 2022.

\subsubsection{Pulsatile Flow}

The first generation of implantable LVADs mimicked the physiological action of the heart producing pulsatile flow. Current continuous flow VADs are superior to the first generation devices with their small size enabling implantation, longer durability, better energy efficiency, less surgical trauma, and reduced incidence of infection, while also having better outcomes post-HTx [56]. However, pulsatile flow offers certain advantages with less vital organ injury and systemic inflammation [116,117]. Kato et al. compared myocardial function and structure in patients implanted with pulsatile- and continuous-flow VADs [118]. They found that LV systolic and diastolic function was better in patients with pulsatile devices, having increased levels of BNP, TIMP-4 and MMP-9. Bartoli et al. reported that pulsatile flow preserved physiological values of myocardial energy utilization and vascular hemodynamics, such that when pulsatile unloading increased, normal LV pressures were maintained; 
however, under continuous flow, the pressure-volume relationship collapsed and the aortic valve remained closed [119]. To combat the complications associated with continuous-flow VADs, the HeartMate 3, a centrifugal pump, was designed to have intermittent speed reduction, to reduce stasis in the pump, as well as providing artificial pulsatility $[120,121]$. This device could be utilized as a cardioprotective strategy, targeting complications such as AI and improving LV systolic and diastolic function, as well as end-organ and microcirculatory perfusion.

Similarly to VADs, V-A ECMO patients can experience complications attributed to continuous flow. Continuous flow with V-A ECMO causes microcirculatory dysfunction [122], and is likely a key factor in contributing to coronary hypoxia. Currently, there are few ECMO systems capable of producing pulsatile flow, one example, however, is the i-cor system by Xenios. A recent study showed that pulsatile flow of this system led to improved renal function and systemic vascular tone in an adult swine model [123]. In addition, other studies have also suggested that pulsatile perfusion may help reduce systemic vascular resistance, and improve myocardial blood flow [124,125]. These benefits are likely to have a significant impact on the outcome of patients suffering cardiogenic shock, as well as other ECMO-related complications, such as acquired von Willebrand syndrome and acute kidney injury [126].

\subsubsection{Heparin}

Studies have previously reported cardioprotective effects of heparin and its low-molecular-weight derivatives (LMWH). Their applications in AMI are well-documented [127]. Heparin and LMWH (e.g., $\mathrm{N}$-acetylheparin, enoxaparin) have been shown to protect the heart against IRI in several ex vivo and in vivo animal models, with improvements in creatinine kinase, end-diastolic pressure, inflammatory responses and infarct size evident with heparin treatment prior to ischemia [128-131]. Application of heparin or LMWH also resulted in reduced activation of the complement pathway, and heparin also promotes dimerization of CXCL12, which is the cardioprotective form of CXCL12 (as compared to monomeric) [132]. The cardioprotective effect of heparin, however, is independent of its anticoagulation properties. There were clear hemodynamic complications of heparin being used as a cardioprotective agent in ECMO. In contrast, LMWH was successfully used in an observational study of $>60 \mathrm{~V}-\mathrm{V}$ ECMO patients [133]. Another consideration is that most of these studies were reported $\sim 20$ years ago, with very little clinical development of heparin as a cardioprotective agent over this time. Heparin plays an essential role in ECMO (and other cardiac-related interventions and surgeries) and may possesses actions that are beneficial to the heart. However, its cardioprotective effect in the context of ECMO and MCS in general is yet to be delineated. Its use must also be carefully balanced with its effect on potential bleeding complications, which is still one of the most lethal complications associated with V-A ECMO and MCS.

\subsubsection{Mitochondrial Transplant}

Ischemia-reperfusion injury (IRI) has long been associated with mitochondrial dysfunction. Consequently, transplantation of respiratory competent mitochondria into tissues injured by IRI has recently been proposed and tested in vitro, ex vivo and in vivo with IRI [134-145]. Mitochondria were isolated from subjects' own skeletal muscle tissues and injected into the left ventricles. In the porcine model [138], several cardioprotective markers were observed following mitochondrial transplant, including increased extracellular myocardial ATP, intracellular ATP synthesis, up-regulation of pathways of energy generation and cellular respiration, and increased expression of cardioprotective cytokines (EGF, GRO, MCP-3 and IL-6). These molecular changes were coupled to a significant reduction in infarct size and cell death. Recently, mitochondrial transplant enabled extension of cold ischemic preservation of the donor heart [141]. Mechanistically, autologous mitochondria are endocytosed by cardiomyocytes using an actin-dependent mechanism, and improve mitochondrial respiratory function and mitochondrial DNA levels [142]. In addition, mitochondrial transplant of allogeneic and syngeneic mitochondria does not stimulate an immune response regardless of exposure 
frequency, or induce production of damage-associated molecular pattern molecules (DAMPs) [144]. In a recent pilot study, five pediatric patients supported by V-A ECMO for IR-associated myocardial dysfunction after surgical procedures were treated with mitochondrial transplantation [137]. These patients were exposed to myocardial ischemia after cardiac surgery that could not be improved by surgical intervention or ECMO. There were reported qualitative improvements in LV function, without observable short-term complications. However, this is still a highly controversial subject, with a very small sample size [146]. In particular, procedures performed in preclinical studies were significantly different from the clinical study where outcomes were qualitative in nature and must be progressed and interpreted with caution.

\subsubsection{Mesenchymal Stem Cells}

Mesenchymal stem cells (MSCs) are multipotent adult stem cells that have gained interest for their immunomodulatory potential [147]. MSCs are present in adult blood marrow and upon undifferentiation, could be induced to differentiate into a range of cell types, including adiopocytic, chondrocytic or osteocytic lineages [148]. MSCs are also known for their regenerative and repair mechanisms upon tissue and cellular damage, mainly through mitochondrial transfer in the context of brain injury, cardiac myopathies, muscle sepsis and lung injury $[149,150]$. However, the exact cellular signaling pathways involved in mitochondrial transfer remain to be elucidated $[150,151]$. Currently, one of the most promising applications for MSCs is graft versus host diseases following bone marrow transplantation [152,153]. Recently, our group has examined the effect of MSCs in ECMO, and observed an immunomodulatory effect of MSCs as expected, with reduced levels of pro-inflammatory cytokines observed [153]. However, due to the natural plastic-sticking properties of MSCs, our studies concluded it is incompatible with the current ECMO setting. It severely and irreversibly clotted the ECMO oxygenator, resulting in a rapid decline in ECMO performance [152]. Further studies aimed at improving the integration of MSCs in ECMO. In particular, a platform that allows the benefit of MSCs without direct contact of the oxygenator is warranted.

Similar to the advantages that MSCs may offer in ECMO, the combination of MSCs and long-term VAD support is an attractive concept and may offer significant advantages for myocardial recovery over using these therapeutic approaches separately. VADs have been shown to allow recovery of the heart at a molecular and cellular level; however, translation of this into clinically functional cardiac recovery, where patients are weaned from the VAD is relatively rare [154]. Thus, combining cell treatment may assist in bridging the gap between molecular and cellular recovery and restored cardiac function. Zheng et al. conducted the only pre-clinical safety and feasibility study to date [155]. This study was conducted in six sheep, combining LVAD implantation and transendocardial injections of allogenic sheep mesenchymal precursor stem cells (MPCs). Here, myocardial infarction was induced (day 0), followed by LVAD implantation (day 30) and cell injection (day 30 or 45). Five sheep tolerated all procedures and histologic analysis confirmed that the MPCs were successfully delivered; however, measurements of cardiac function were not made during this study. Clinically, Ascheim et al. Ascheim et al. evaluated the safety of intramyocardial injection of 25 million allogenic MPCs delivered at the time of LVAD implantation. They assessed the efficacy of this treatment in thirty patients with either ischemic or non-ischemic HF by evaluating LV function during short intervals of temporary reduction of LVAD support (pump speed) [156]. At 90 days post-implantation, there were no differences between the treatment and control groups for adverse events, and the treatment group showed a slightly higher rate of successful temporary weaning from the LVAD ( $50 \%$ vs $20 \%$; $p=0.24)$. However, by 12 months there was no difference between groups. In the largest study to date, Yau et al. conducted a randomized trial in 159 patients, with intramyocardial injections of 150 million allogeneic MPCs [157]. The results of the trial indicated that there was no difference between the treatment and control group with respect to temporary weaning for the LVAD at 6 months and thus, the findings do not support the use of MPCs for promoting cardiac recovery at this stage. 


\section{Heart Transplantation}

Heart transplantation (HTx) is the definitive and most effective therapy for qualifying patients with end-stage HF. Donor hearts are predominantly sourced from brain dead (BD) donors; however, interest is growing in accessing hearts from patients that have died due to circulatory death (DCD donors). The demand for donor hearts continues to grow, but supply does not. Many donor hearts are discarded ( $>75 \%$ of donor hearts in Australia are discarded) [158], waitlists and deaths on waitlists are excessive and expanding [159], and the majority of HF patients are never assessed for HTx due to donor heart shortages and stringent recipient criteria [160].

Standard clinical practice using BD donors for HTx is a limitation that contributes to the high discard rate of donor hearts. Pre-existing damage, systemic factors, age, and BD-related injury in the donor can significantly prevent organ donation and increase the risk of primary graft dysfunction (PGD) in the recipient [161-163]. In the first 30 days post-HTx, PGD and multi-organ failure are responsible for $66 \%$ of the mortality-with most deaths attributed to PGD [163]. Our understanding of pathophysiological changes occurring with PGD are limited; however, a multi-centre survey identified IRI upon autopsy was responsible for $48 \%$ mortalities caused by PGD [163].

Brain death induces contractile dysfunction of the donor heart, and sensitizes the heart to IRI via the characteristic catecholamine 'storm', cardiac ischemia, hormonal dysregulation, mitochondrial and cytosolic calcium overload, changes to calcium sensitivity, endothelin and inflammation activation [161, $162,164]$. During the process HTx, the donor heart is exposed to a combination of severe injuries that are unavoidable due to the nature of the procedure: BD (and related aforementioned injuries), cold ischemic preservation whilst in transit, warm ischemia during explant and implant, and reperfusion injury following restoration of blood flow in the recipient. Although essential to viability, reperfusion of the already inflamed organ is deleterious [11,165].

Following HTx, a risk of up to $\sim 20 \%$ 90-day mortality persists, depending on the recipient's disease state [163]. Evidently, the danger continues well beyond receiving a new a heart, and despite best practice, these injuries are currently unavoidable. Early, effective and persistent intervention is key to reduce the extent of graft dysfunction, long-term risks (e.g., cardiac allograft vasculopathy, CAV), survival and quality of life post-HTx. Cardiac dysfunction post-ischemia can be alleviated with various cardiac conditioning strategies in animal models; however, these strategies have shown mixed results clinically. Clinical cardioprotection, while desirable, has often failed due to the inherent molecular changes that occur with age, disease, and chronic pharmacotherapy [16], or due to flaws in the experimental design of both human and animal studies [14]. In the context of HTx, there are additional factors at play that should be considered to achieve effective cardioprotection in this cohort, largely immunosuppression (Figure 2) and inotrope support (Figure 3). 


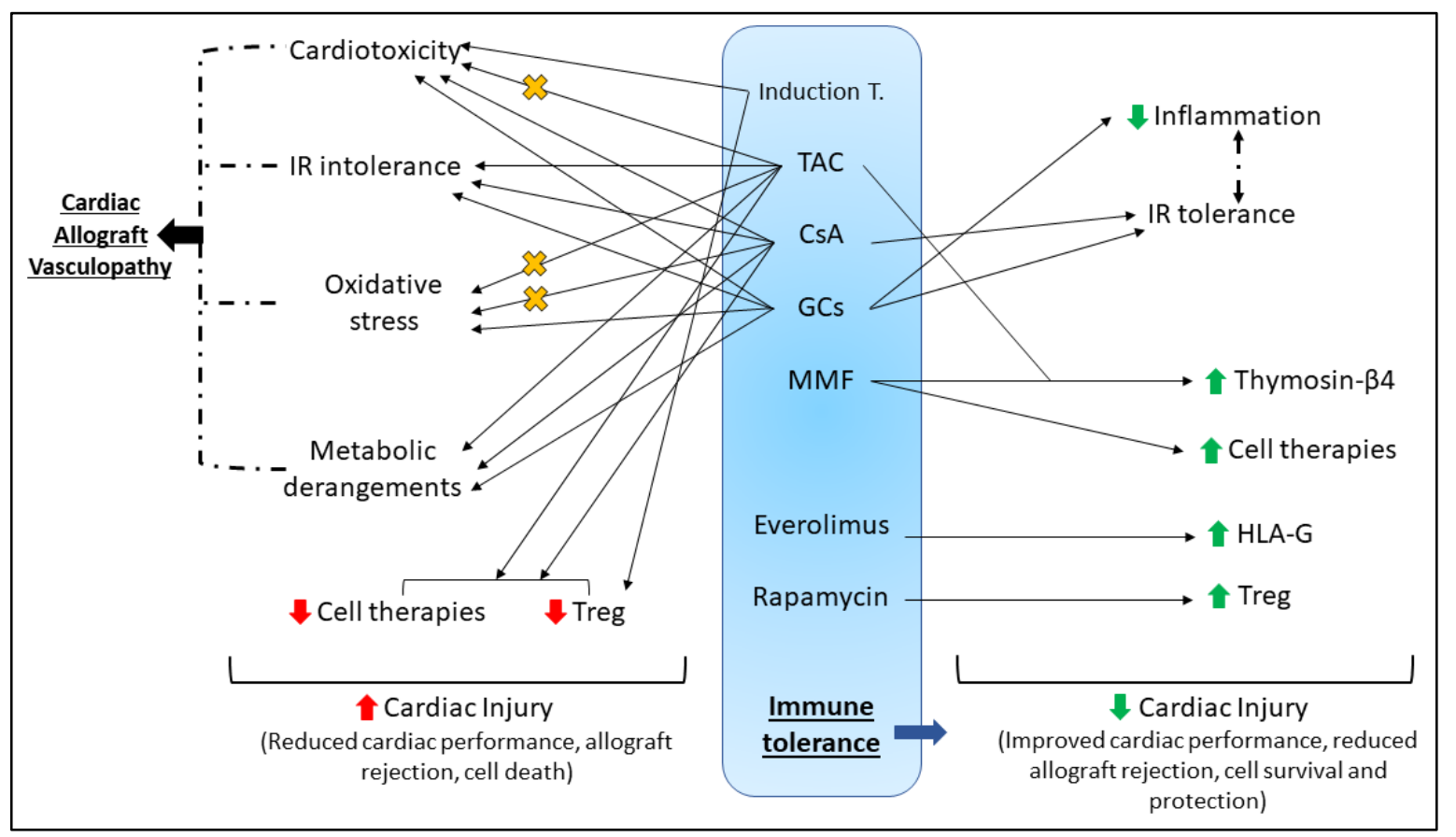

Figure 2. Summary of the complex effects of immunosuppression post-HTx (discussed in Section 4). The goal of immunosuppression in the recipient post-HTx is to develop immune tolerance to the cardiac allograft, thus reducing the chances of rejection and improving long-term survival. Many agents used in induction and maintenance therapy, while critical for the development of immune tolerance, have significant detrimental side effects that could complicate the efficacy of any potential cardioprotective therapeutic; including cardiotoxicity, IR intolerance, oxidative stress and systemic metabolic derangements. These adverse effects are interrelated and well reported to influence each other; notably all contribute to the development of cardiac allograft vasculopathy, worsen cardiac injury and impair patient survival. Conversely, some studies have assessed the efficacy of immunosuppressive agents upon IR tolerance, or have considered immunosuppression for the assessment of other cardioprotective strategies. Cardioprotection using cell therapy, and innate tolerance and protection induced by Treg cells appear to be abrogated by some immunosuppressive agents (e.g., CsA and TAC), yet promoted by others (e.g., MMF, rapamycin). Some agents have been shown to impede the oxidative stress and cardiac dysfunction (denoted by orange X) associated with TAC (e.g., MMF, aliskiren, almesartan) and CsA (e.g., Erdosteine). The complexities of inducing immune tolerance are worthy of important consideration for protecting the cardiac allograft and promoting survival. Induction T-induction therapy; IR—ischemia-reperfusion; TAC—tacrolimus; CsA—cyclosporine A; GCs-glucocorticoids; MMF-mycophenolate mofetil; HLA-G-human leukocyte antigen-G; Treg - T regulatory cells. 


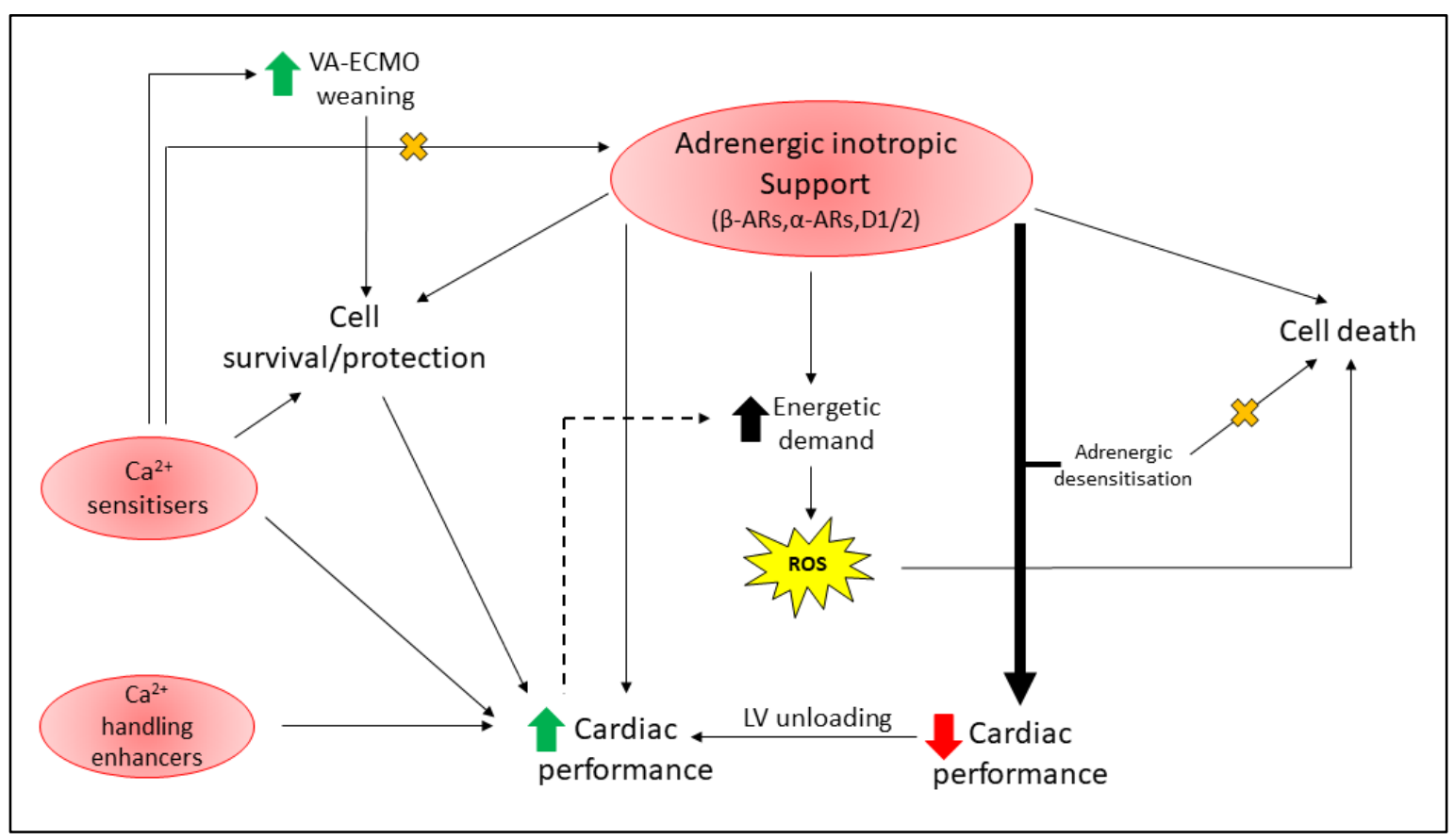

Figure 3. Complications of inotropic support in critically ill cardiac patients (discussed in Section 5). Adrenergic inotrope support is complex depending on the drug employed and its receptor selectivity ( $\beta$-ARs, $\alpha$-ARs, D1/2), with activation of the receptor pathways linked to both cell death and survival signaling. Adrenergic inotropic support is commonly used to improve cardiac performance, and while critical to patient survival, can increase the energetic demand of the already weak heart and promote reactive oxygen species (ROS) production. Elevated oxidative stress in the damaged heart can exacerbate cardiomyocyte death and worsen patient survival. Excessive adrenergic inotrope support (thick black arrow) to maintain hemodynamic control can lead to adrenergic desensitization (to prevent chronic adrenergic toxicity-denoted by orange $\mathrm{X}$ ), at the expense of resultant poor cardiac contractility in critically ill cardiac patients (e.g., HF and post-HTx). $\mathrm{Ca}^{2+}$ sensitizers (e.g., Levosimendan, Omecamtiv mecarbil) appear to promote cell survival through various mechanisms, can facilitate weaning from VA-ECMO, and reduce the requirement for adrenergic inotrope support (denoted by orange $\mathrm{X}$ ); however, they can be arrhythmogenic. $\mathrm{Ca}^{2+}$ handling enhancers have undergone several clinical trials and others are currently underway. Novel pharmacotherapeutics that can improve cardiac performance whilst avoiding energy imbalances and resultant oxidative stress (dotted line as is only reported to occur for adrenergic agents) are desirable in this cohort.

\subsection{Immunosuppression}

Immunosuppressive therapy is a fundamental principle in HTx recipient management against antibody-mediated and cellular rejection, but it is also a careful balancing act to avoid adverse outcomes from robust immunosuppression. Various grades of rejection and resultant graft injury can occur both short- and long-term post-HTx, thus immunosuppression protocols typically exist of induction therapy (administered at the time of transplant/early post-operative period), followed by maintenance therapy that continues for several months-years post-HTx. The International Society for Heart and Lung Transplantation (ISHLT) reports that in 2016, induction therapy was used in 76\% of adult HTx recipients to reduce the risk of rejection [166]. Induction therapy commonly targets T-cell depletion (using anti-thymocyte globulins, anti-lymphocyte globulins and alemtuzumab), and inhibition of the interleukin-2 receptor (e.g., Basiliximib) [166,167]. Maintenance immunosuppression generally involves a combination of corticosteroids (e.g., methylprednisolone, prednisone, prednisolone), a calcineurin inhibitor (CNI, e.g., tacrolimus, TAC; cyclosporine A, CsA), and an antimetabolite (e.g., purine inhibitors azathioprine, AZA, and mycophenolate mofetil, MMF). Long-term, for the prevention of CAV (a common long-term complication post-HTx that impairs the coronary vasculature [168]) or the 
treatment of chronic rejection, a proliferation signal inhibitor (PSI) may be employed (e.g., Sirolimus, everolimus) $[166,167,169]$.

\subsection{Immunosuppression Can Impair Cardiac Function}

\subsubsection{Induction Therapy}

As detailed above, immunosuppression is critical for limiting rejection post-HTx, yet is not devoid of inducing deleterious effects upon patients. Induction immunosuppression using monoclonal antibody-based T-cell therapies has been associated with cytokine release syndrome (CRS). While the pathomechanisms are poorly understood, CRS develops in response to excessive T-cell activation that generates a cytokine storm leading to detrimental outcomes on all major organ systems [170]. Induction agents such as anti-thymocyte globulin (ATG) [171], alemtuzumab [172] and rituximab [173] have all been associated with CRS, and HTx recipients thus require pretreatment with antihistamines, antipyretics and glucocorticoids [167]. In response to the excessive inflammatory response with CRS, the heart may develop adverse cardiovascular complications that while reversible, appear rapidly and are severe (e.g., hypotension, tachycardia, arrhythmia, elevated troponin I release) [170,174].

\subsubsection{Maintenance Therapy}

In the past 10 years, $>75 \%$ HTx recipients (at 1 year post-HTx) reported use of TAC-MMF maintenance therapy combined with a corticosteroid [166]. While key to the maintenance immunosuppression regime for HTx recipients, calcineurin inhibitors tacrolimus (TAC) and cyclosporine A (CsA) have notable cardiotoxic effects. These immunosuppressants inhibit calcineurin through the formation of specific protein complexes that effectively block T- and B-cell activation [175]. Tacrolimus is associated with hypertrophic obstructive cardiomyopathy in pediatric gastrointestinal and liver transplant patients, [176-178], sinus bradycardia [179], cardiac arrhythmia [180], and more recently, dilated cardiomyopathy [181]. While TAC appears to be the preferred CNI of choice over CsA [166], is it reportedly neurotoxic [167], nephrotoxic [182], induces elevated sympathetic activation [183], and does not impede the development of CAV $[175,184-186]$. CsA-mediated cardiotoxicity manifests as impaired cardiac contractility and arrhythmogenic responses, potentially due to enhanced apoptosis [187], oxidative stress [188,189] and excessive intracellular calcium sequestration [190]. Furthermore, CsA abrogates neuronal mitochondrial activity [191], leading to impaired cardiac autonomic function and hemodynamic compromise [192]. Similarly to TAC, CsA does not lower the incidence of CAV. This may in part be linked to the observation that clinical doses of CNIs may not completely abrogate calcineurin, leading to partial immune system activation and resultant development of CAV [193]. Both TAC and CsA are associated with the development of metabolic derangements. In comparison to TAC, CsA appears to potentiate hyperlipidemia and hypertension post-HTx more, two risk factors that contribute to CAV development. Tacrolimus has also been associated with the development of new-onset diabetes and impaired glucose tolerance following both heart and renal transplant [175,184,194-198]. Despite these cardiovascular and metabolic complications, TAC and CsA have notably improved medium-term longevity and are equally effective at limiting acute rejection post-HTx [184,194,199]. Immunosuppressive therapy is quintessential to management and recovery post-HTx, however it is clear that both metabolic and cardiac dysfunction may not be avoided in some patients.

Glucocorticoids (GC, e.g., prednisone, methylprednisolone, prednisolone) are a core component of maintenance immunosuppressive treatments to promote immune tolerance post-HTx. Mechanistically, GCs bind cytoplasmic glucocorticoid receptors, and beneficially regulate inflammation and immunosuppression by both transcriptional and non-transcriptional pathways [169]. To reduce inflammation, GCs have been shown to attenuate leukocyte adhesion to the endothelium, and adhesion molecule expression of endothelial cells [200]. Furthermore, GCs reduce cytokine expression at a transcriptional level, and block macrophage/monocyte infiltration [201]. While it appears that mechanistically, GCs may offer a protective advantage in the heart, several studies report that GCs 
worsen outcomes from IRI [202-206]. Indeed, a review of clinical trials and meta-analyses in 2014 revealed that despite the distinct anti-inflammatory actions of GCs, no clear benefit to mortality or incidence of myocardial infarction was identified by any clinical trial [200]. Regardless, steroids remain critical to immune tolerance, and are thus an important component of immunosuppressive induction, maintenance and rejection therapies $[169,207]$. Interestingly, faster withdrawal of steroid therapy does not impact early rejection post-HTx [208,209]. Steroid withdrawal is a desired goal, as long-term steroid therapy is well-reported to be associated with significant comorbidities such as diabetes, obesity, hyperlipidemia and hyperglycemia [169,210-212]. These risk factors undoubtedly aggravate the incidence of CAV, which affects almost $30 \%$ patients within 5 years post-HTx, and increases to $47 \%$ within 10 years [166]. Steroid use also reportedly impairs wound healing [169,203], is associated with left ventricular free wall rupture in AMI [203], and is prothrombotic [213]. While outside the direct scope of this review, metabolic risk factors and disorders unequivocally ameliorate many cardioprotective mechanisms in both animal models and clinical studies, reviewed in detail elsewhere $[13,16,214,215]$.

\subsection{Cardioprotection and $H T x$}

During HTx, the grafted heart is unavoidably exposed to extended IRI, which can significantly impede post-HTx cardiac function in the recipient, and enhance post-HTx morbidity and mortality. Many research groups have examined variations of cardioplegic solutions to precondition the donor heart upon retrieval, in an attempt to limit IRI with varied success [216,217]. Novel avenues to prolong the time a donor heart can be stored without aggravating post-HTx graft function are being actively investigated and used clinically with notable success [218-222]. While these are important components within the process of HTx, they are outside the scope of this review.

\subsubsection{Intrinsic Immune Responses Aid Cardiac Recovery}

Despite significant immune and cardiovascular challenge, intrinsic responses remain active in the heart post-HTx. Early post-HTx, strategies aiming to shift the balance away from graft destruction and effector $\mathrm{T}$ cells, but towards graft regulation and regulatory $\mathrm{T}$ (Treg) cells is clinically desirable [223]. Regulatory immune cells contribute to immune tolerance, leading to reduced graft rejection and improved long-term survival, and Treg cell promotion can be manifested through specific immunosuppression [224], cellular therapy [223] or alloantigen pretreatment [225]. In a mouse model of myocardial IRI, Xia et al. showed that Treg cells aid in myocardial functional recovery following IRI by activation of RISK-associated Akt and ERK1/2 signaling to reduce cardiomyocyte apoptosis, and suppression of chemokine production to limit neutrophil infiltration via a CD39-dependent mechanism [226]. In a model of heterotopic heart-kidney cotransplantation where recipients received CsA, cardiac allograft function, survival and ultrastructure were not impacted despite significant inflammatory, IR and histoincompatability challenges [227]. The preserved cardiac function and allograft survival was attributed to the development of immune tolerance, which occurred despite the excessive proinflammatory settings.

\subsubsection{Cardioprotection Despite Immunosuppression}

While compulsory immunosuppression can impair myocardial function, some pharmacotherapies (including some immunosuppressants) retain their ability to induce a protected cardiac phenotype. Myocardial and/or soluble human leukocyte antigen-G (HLA-G) expression has been shown in several studies to reduce cardiac allograft rejection and vasculopathy post-HTx [228,229]. Expression of HLA-G appears more prominent in HTx recipients receiving everolimus (a PSI) compared to mycophenolate mofetil (MMF), and this expression is not affected by CsA treatment [230]. Alternatively, the antioxidant properties of MMF can reduce the oxidative stress and DNA damage induced by TAC [231]. Treatment with an angiotensin receptor blocker (almesartan) or a renin inhibitor (aliskiren) limited cardiac injury biomarker (lactate dehydrogenase, creatine kinase) expression in serum, preserved cardiac 
structure and effectively reduced oxidative stress in TAC-treated hearts [232]. Targeting oxidative stress, erdosteine (a mucolytic with antioxidant properties) co-treatment with CsA for 21 days reduced the myocardial structural derangements, interstitial fibrosis and improved the oxidant/antioxidant balance [189]. While the aforementioned studies show that immunosuppression complications may be rescued with other pharmacotherapies, Behbod et al. demonstrate that inhibition of Jak3 using tyrphostin AG-490 potentiates the beneficial immunosuppressive actions of CsA and extends cardiac allograft survival [233]. Additionally, CsA is capable of reducing troponin I and creatinine kinase release following reperfusion [234]. However, clinical outcomes in myocardial infarction patients were no different to placebo, and cardiac remodeling persisted when CsA was delivered prior to [235] or at reperfusion [236]. Ikeda et al. demonstrated that when CsA was linked to nanoparticles and administered intravenously at reperfusion, CsA improved myocardial functional recovery, reduced cardiac remodeling, and was more effective at inhibiting mPTP opening [237].

Despite several reports that GCs worsen IRI outcomes (detailed above), GCs also protect the heart against IRI by restoring post-ischemic contractile function [238], reducing infarct size [239,240], cardiac troponin T [241] and I [242], can prolong cardiac allograft survival [241,243], and these positive effects may be improved with simvastatin co-treatment [241]. Mechanistically, GC-mediated tolerance to IRI (and associated inflammation) reportedly inhibits of NFKB [244,245], activates endothelial nitric oxide synthase (via a PI3K/Akt-dependent pathway) and annexin-1 [169,245], and modulates angiotensin II receptor subtype expression [238]. Furthermore, exposing hearts to dexamethasone 24 hours prior to IR increases expression of cyclooxygenase 2 (COX-2) [246] and activates lipocalin-type prostaglandin D (PGD) synthase [246,247], with converging end effects to increase prostaglandin $\mathrm{D}_{2}$ production $\left(\mathrm{PGD}_{2}\right)$ [248]. Elevated PGD2 expression limits oxidative stress by increasing Nrf2 transcription factor levels $[248,249]$.

Methylprednisolone (MP) is the primary GC of choice for use in HTx recipients [166]. Donor BD induces significant RV dysfunction and pro-inflammatory cytokine upregulation, which is reportedly attenuated with MP treatment either early pre-or post-BD induction [250,251]. Altering the balance of the pro- and anti-inflammatory profile with MP administration is not influenced by $\mathrm{NF} \kappa \mathrm{B}$ or $\beta$-adrenoceptor signaling pathways [251]. Furthermore, reduced IL- 8 and $\operatorname{TNF} \alpha$, and increased anti-inflammatory IL-10 were observed when steroids were administered earlier in the immunosuppressive protocol to protect against CPB-induced inflammation [252]. Sandha et al. have recently demonstrated that MP is also beneficial in DCD settings, effectively reducing pro-inflammatory cytokines in DCD hearts with MP delivery at reperfusion [253].

Akin to many cardioprotective agents, the timing of steroid delivery likely influences the degree of protection. Wan et al. demonstrated that MP administration $1 \mathrm{~h}$ prior to cardiac surgery is more effective at reducing the pro-inflammatory profile compared to delivery at the end of CPB [252], and administering MP in the CPB prime provides no additional cardioprotection (identified by expression of heart-type fatty-acid-binding protein) vs. induction of anesthesia [254]. A human study found that significantly reducing the steroid dose during BD donor management did not worsen donor heart function or rate of successful HTx, and preserved glucose handling [255]. Steroids administered immediately prior to HTx improved post-HTx cardiac contractility and hemodynamic stability [256].

\subsubsection{Cardioprotective Cellular Therapies and Immunosuppression}

Cardiovascular cellular therapies and regenerative medicine have shown promise in alleviating infarction and restoring post-ischemic function in many animal models. In the context of HTx and associated immunosuppression, several cell therapies identified have improved cardiac allograft function and survival. Indeed, in some circumstances, correct immunosuppression choice has improved cell engraftment with resultant beneficial effects on the heart. Huber et al. [257] have previously shown that an alternative short-course immunosuppressive regime using two co-stimulation adhesion inhibitors (CTLA-4 and anti-LFA-1) permitted enhanced survival of human embryonic stem cell-derived endothelial cells (hESC-EC) and cardiomyocytes (hESC-CM) in the ischemic mouse heart. Furthermore, 
improved hESC-EC engraftment following this immunosuppressive treatment significantly improved post-ischemic cardiac function and reduced infarct size [257]. Conversely, proliferation and quantity of hESC-CM is reduced by clinically-relevant doses of CsA and TAC [258]. In a heterotopic HTx model where recipients were treated post-operatively with TAC and MMF, gene transfer of thymosin ß4 (a G-actin-sequestering molecule associated with cell survival, immunomodulation, improved myocardial function and infarct reduction $[259,260]$ ) improved post-HTx survival and reduced graft rejection through anti-inflammatory, pro-angiogenic and improved cardiomyocyte survival mechanisms [261]. Mesenchymal stem cells (MSCs) have gained significant attention for their potential as a therapeutic for cardiac disease, demonstrating functional tolerance and protection against infarction following cardiac ischemia [262-265]. They also possess immunomodulatory actions as activators of Treg cells, demonstrating their potential benefit in settings of clinical HTx. Cell therapy using MSCs reportedly induces long-term allograft acceptance when applied with MMF [266]. However, this beneficial effect is not only lost in the presence of CsA, but low-dose CsA also promoted allograft rejection in these settings [267].

Due to the role of Treg cells in promoting graft tolerance post-HTx, development of a Treg-based therapy that could reduce the reliance upon chronic immunosuppression while promoting allograft tolerance is clinically desirable [268-272]. Antigen-specific Treg cells (isolated from T-cell receptor transgenic mice) appear superior to polyclonal Treg cells due to their enhanced nonspecific suppressive function at sites of localized inflammation [273-275], such as the cardiac allograft post-HTx. Pilat et al. previously demonstrated that additional Treg treatment at the time of bone marrow transplantation in the recipient (performed 6-8 weeks prior to heterotopic HTx to precondition the recipient with fully mismatched donor bone marrow cells) prevents the development of chronic rejection in cardiac allografts [276]. While Treg-based therapies may be useful in promoting cardiac allograft survival, Treg activity is modified by immunosuppression. Rapamycin promotes functional Treg cell numbers in vivo and in vitro $[277,278]$ and assists in promoting long-term cardiac allograft survival following alloantigen-specific Treg cell treatment [275]. However, CNIs [279], alemtuzumab and ATG [280] reportedly reduce Treg populations.

Immunosuppression is an important component of recipient management to enhance post-HTx recovery and survival. However, these drugs have well-reported adverse effects upon the heart (and rest of the body) that complicate post-HTx recovery. Indeed, a recent study assessing the ISHLT registry data found that recipient age and immunosuppressive therapy likely influence post-HTx mortality, proposing that immunosuppression should be tailored to the recipient age [281]. While some cardioprotective therapies have shown promise at positively influencing post-HTx myocardial function and survival, co-treatment immunosuppression can limit their protective efficacy. Consideration of the target cohort (e.g., age, comorbidities, drug therapies) is vital to find an effective cardioprotective strategy, and in the context of HTx, immunosuppressants, should also be considered.

\section{Cardioprotection With Inotropic Support}

The therapeutic goal of inotropic agents is to increase cardiovascular performance whilst improving end organ perfusion. Inotrope support is required for hemodynamic management of critically ill patients-including BD donors, cardiac patients following surgery (e.g., HF management, post-VAD implantation and post-HTx), and ECMO patients [282,283]. For a comprehensive review, Maack et al. discussed the use of inotropic agents in the context of HF in a position statement by the European Society of Cardiology [284]. Interestingly, many of the pathways and signaling components activated by inotropes have been linked to cardioprotective mechanisms across model systems and species. Despite this positive link, long-term inotrope support is associated with poor survival and cardiovascular outcomes [282,284,285]. Currently, these agents can be loosely classified into three main arms based on their mode of action (discussed below); adrenergic stimulants, myofilament calcium sensitizers and agents that improve cytosolic handling independent of adrenergic signaling [284]. 


\subsection{Adrenergic Stimulants}

Adrenergic stimulants, including adrenaline, noradrenaline, dopamine and dobutamine, are the most frequently used inotropic agents available to the clinician (Table 1). Adrenergic stimulants activate beta-adrenergic ( $\beta_{1} / \beta_{2}$-ARs), alpha-adrenergic ( $\alpha_{1}$-ARs) and dopaminergic receptors (D1-/D2-like). Commonly used in combination targeting myocardial $\beta_{1}$-ARs and vascular $\alpha_{1}$-ARs, the use of these inotropes constitutes a careful balancing act between therapeutic action and cardiovascular compromise.

Table 1. Adrenergic stimulants used, and their receptor target affinities and therapeutic aim.

\begin{tabular}{cccccc}
\hline Drug & \multicolumn{5}{c}{ Receptor Target } \\
\hline Adrenaline & $\alpha_{1}$-AR & $\beta_{1}$-AR & $\beta_{2}$-AR & D1/2 & Therapeutic Aim \\
\hline Noradrenaline & ++++ & +++ & ++++ & 0 & $\begin{array}{c}\text { Vasoconstriction } \\
\text { Positive inotropy and } \\
\text { chronotropy } \\
\text { Positive inotropy and } \\
\text { chronotropy } \\
\text { Vasoconstriction }\end{array}$ \\
Dobutamine & ++ & +++ & + & 0 & $\begin{array}{c}\text { Positive Inotropy and } \\
\text { chronotropy } \\
\text { Vasodilation }\end{array}$ \\
& +++ & ++ & +++ & ++++ & $\begin{array}{c}\text { Positive Inotropy and } \\
\text { chronotropy }\end{array}$ \\
\hline
\end{tabular}

\subsubsection{Beta-Adrenoceptors}

$\beta_{1}$-adrenoceptors ( $\beta_{1}$-AR) are the most prominent adrenoceptor in the heart, and activation of this pathway to improve cardiac performance and survival may come at a cost. Mechanistically, inotropes used to stimulate this pathway (e.g., dobutamine, adrenaline, noradrenaline) can increase intracellular calcium overload, cardiomyocyte apoptosis, myocardial oxygen demand, lactate production and incidence of arrhythmias $[282,284,286]$. These adverse consequences become particularly important for patient management following myocardial infarction, where in the case of cardiogenic shock, inotropic support via adrenergic stimulants can potentially worsen prognosis [284]. Long-term use in HF patients is also potentially detrimental and perhaps ineffective due to the impaired $\beta$-AR signaling that occurs in HF [287]. Furthermore, chronic isoproterenol administration has been repeatedly used in animal models to induce myocardial damage [288-291]. While $\beta$-AR stimulants are vital to elevate cardiac performance, equally, their use can impair cardiac function.

Stress cardiomyopathy, or takotsubo (TS) syndrome, shares similar features with the cardiac dysfunction commonly seen during donor BD: excessive catecholamine overload on the heart, and (somewhat) reversible contractile dysfunction [292]. TS develops in response to elevated circulating and postganglionic catecholamines [293], and further exogenous catecholamine administration acts synergistically to impair cardiac function and can increase mortality [294]. Models of TS using isoproterenol have highlighted the importance of $\beta_{2}$-ARs in the generation of TS [295,296], which involves a switch in Gs- to Gi-coupling in the stimulus trafficking process $[293,296]$. Coupling to Gi increases p38 MAPK and PI3K/Akt signaling, inducing a fall in contractility, attempting to protect the heart against catecholamine toxicity $[296,297]$. This $\beta_{2}$-AR-Gi cardio-inhibitory effect can be exacerbated by $\beta$-blockers known to have $\beta_{2}$-AR-Gi agonsim such as propranolol, and to a lesser extent, carvedilol [296]. Neither drug, however, increased overall mortality in TS. The classical TS morphology is due to the regional differences in $\beta_{2}$-AR expression, decreasing in density from the apex (highest) to the base (lowest) [296,297]. The denervated heart post-HTx is reportedly hypersensitive to $\beta$-AR stimulation [298,299], even in the presence of $\beta$-blockade [299]. This hypersensitivity reportedly occurs in response to reduced $\beta$-AR density over time post-HTx [298,299]. Gilbert et al. also showed that this hypersensitivity was presynaptic, and myocardial interstitial epinephrine levels were likely elevated 
due to an absent neuronal uptake mechanism [298]. These collective observations are in agreement with IR studies demonstrating reduced $\beta$-AR density and elevated GRK2 levels post-ischemia [300-302].

The role of $\beta$-agonism in cardioprotection is controversial, with many studies reporting protective and deleterious actions of both $\beta_{1}$ - [303-307] and $\beta_{2}$-adrenoceptors [306-310] ( $\beta_{1}$ - and $\beta_{2}$-Ars, respectively) in the context of myocardial IRI. $\beta$-agonism that promotes Gs-PKA pathway activation is typically associated with myocardial damage, and activation of the Gi-ERK pathway is prosurvival; however, there are exceptions to this rule $[305,308]$. These mixed effects may reflect cardiac vs. extra-cardiac responses of $\beta$-ARs, variances in drug selectivity for $\beta$-AR subtype, and non-specific actions of $\beta$-AR responses [303]. Interestingly, a unique cardioprotective phenomenon termed sustained ligand-activated preconditioning (SLP) induces potent tolerance to IRI through regulation of the $\beta_{2}-A R-G \alpha_{s}-P K A$ signaling pathway [308]. Distinct from traditional cardioprotective stimuli, these unique signaling mechanisms render SLP protective in the aged [311] and comorbid [312] myocardium, which is also insensitive to chronic $\beta$-blockade [303], caveolin-3 knockout [27].

\subsubsection{Alpha-Adrenoceptors}

Cardiac $\alpha$-adrenoceptor ( $\alpha$-AR) activation by adrenaline (or epinephrine) or noradrenaline (or norepinephrine) leads to downstream release of intracellular calcium and protein kinase $C$ activation, resulting in vasoconstriction [313]. Increasing evidence now suggests that $\alpha 1$-AR activation can increase myocardial contractility, and chronic $\alpha 1$-AR stimulation initiates adaptive responses to protect from myocardial stress. Sustained $\alpha 1$-AR activation reportedly induces physiological hypertrophy that does not impair cardiac function, nor produce fibrosis [313-315]. In various cell and animal models, $\alpha 1$-AR activation can ameliorate apoptosis and necrosis induced by IRI [316-318], hypoxia [319], norepinephrine- [320] and isoproterenol-induced cardiotoxicity [319]. Mechanistically, this survival signaling likely involves ERK1/2 and Bcl-2 (and related family members), to preserve mitochondrial membrane integrity and increase expression of transcription factors that promote cardiomyocyte survival (GATA4 and NFAT) [313]. In the heart, $\alpha 1$-ARs comprise approximately $10 \%$ of total cardiac adrenergic receptor population [313]. Thus, while $\alpha 1$-AR signaling may be cardioprotective, adrenergic stimulants that may activate $\alpha 1$-AR also bind $\beta$-ARs that form the largest myocardial adrenoceptor population, and adverse $\beta$-AR-mediated consequences likely dominate when treating critically ill patients.

\subsubsection{Dopamine Receptors}

Dopamine receptors can be classified into two superfamilies, D1- and D2-like receptors that have either direct (D1-like) or indirect (D2-like) vasodilatory effects on smooth muscle. Both receptor subfamilies are found in vascular and cardiac tissue, with D1-like receptor activation increasing adenylyl cyclase (AC) activity and downstream calcium channel activation, and D2-like receptors inhibiting this pathway [321-323]. The ligand dopamine, however, has complex dose-dependent actions. At low doses $(\leq 5 \mu \mathrm{g} / \mathrm{kg} / \mathrm{min})$, dopamine induces vasodilation via D1- and D2-like receptors. Low-dose dopamine support in organ donors limits the risk of right heart failure (pediatric recipients) [324] and three-year mortality (adult recipients) post-HTx [325]. At high concentrations, dopamine activates $\beta$ - and $\alpha_{1}$-ARs, causing positive chronotropy, inotropy and vasoconstriction [282]. While dopamine demonstrates important roles in maintaining cardiac output and systemic perfusion, its actions are not without untoward effects. Dopamine exaggerates intracellular calcium levels following IR, such that when coupled with impaired post-ischemic calcium cycling, this leads to compromised ventricular relaxation and cardiomyocyte apoptosis, despite enhanced systolic function [326]. Interestingly, propofol postconditioning reportedly allows preservation of dopamine-induced inotropy, but ablates the associated cardiomyocyte apoptosis [326]. In clinical situations where neuronal norepinephrine stores are depleted (e.g., post-HTx following surgical denervation or end-stage HF), the effectiveness of dopamine to provide inotropic support may be compromised [327]. 
Dopamine has also been implicated in mechanisms of cardioprotection. Pharmacological preconditioning with dopamine improves post-ischemic functional recovery and reduces infarct size in a dose-dependent manner via $\alpha_{1}$-ARs [328] and dopamine D2 receptors [329]. Indeed, activation of dopamine D2 receptors is reportedly involved in mechanisms of ischemic pre- [329] and postconditioning [330]. The D2 receptor-mediated cardioprotection that occurs with ischemic postconditioning has been shown to mediate translocation of protein kinase $\mathrm{C}-\varepsilon$ (PKC- $\varepsilon$ ) to the cell membrane [331], and inhibit mPTP opening via activation of ERK1/2, PI3K-Akt-GSK3 $\beta$, and PKC- $\varepsilon$ [332]. Interestingly, $\mathrm{N}$-octanoyl dopamine (NOD), a dopamine derivative, has been shown to protect against cold ischemic injury in neonatal rat cardiomyocytes [333] and in transplanted rat hearts exposed to NOD during donor brain death [334]. While NOD preserves cardiac contractility [334,335], mechanistically, NOD appears cardioprotective via its lipophilic and antioxidant properties [333,334], and has the ability to reduce the expression of apoptotic and pro-inflammatory markers in cardiac tissue [335].

\subsection{Complications with Adrenergic Inotrope Support}

\subsubsection{Adrenergic Desensitization}

Following repeated stimulus exposure (e.g., as occurs in HF, BD, high inotrope support), adrenergic desensitization occurs to alter both receptor function and expression. Here, G-protein coupled receptor kinases (GRKs), particularly GRK-2, mobilize to the cell membrane and phosphorylate agonist-occupied ARs, preventing further receptor activation. $\beta$-arrestins are then recruited to the site, promoting $G$ protein uncoupling and eventual receptor internalization [336]. Adrenergic desensitization prevents chronic adrenergic toxicity, albeit at the expense of contractility in settings of HF [337] and following HTx [292].

In the context of organ donation following $\mathrm{BD}$, the desensitization process is of particular importance. A defining feature of $\mathrm{BD}$ is the catecholamine storm, increasing post synaptic release of adrenaline and noradenaline in an attempt to counteract impaired cerebral perfusion, leading to a severe hyperdynamic cardiovascular response in donors [338,339]. It is hypothesized that this catecholamine overload potentiates adrenergic desensitization in donor hearts, and promotes myocardial dysfunction. Inotropic support is vital for management of the hemodynamic compromise during donor BD, however, in a potentially desensitized organ, additional exogenous catecholamine exposure may only add insult to injury. Indeed, high inotrope dependence and significant myocardial dysfunction can prohibit organ donation (based on medical grounds) [340,341]. Due to the shortage of acceptable donor hearts, several studies have demonstrated that using these "extended criteria" donors on high inotrope support is an acceptable strategy for expanding the donor pool [342-344]. Conversely, left ventricular mechanical unloading (as occurs with VAD implantation, V-A-ECMO) increases $\beta_{1}$-AR [345] and $\beta_{2}$-AR mRNA expression (also tolerance to IRI) [346], and reduces GRK2 expression and activity [347,348], which may explain the improved $\beta$-AR responsiveness and total $\beta$-AR density observed post-VAD implantation [347-349]. Several studies have demonstrated restoration of improved cardiac $\beta$-AR signaling following LVAD support, Post-HTx patient management also requires inotropic support, commonly employing adrenergic stimulants. Similar to HF, however, HTx recipients may face the deleterious effects of desensitization. Studies have shown that exposure to permanent LAD occlusion or IRI (as occurs with organ storage and subsequent HTx) induce reductions in adrenergic receptor density $[300,301,350]$. Indeed, adrenergic stimulation at reperfusion further aggravates reperfusion injury by causing calcium overload, leading to apoptosis [351]. Increasing evidence demonstrates that GRK2 is an important signaling molecule independent of the desensitization process that can impair cardiac function, and strategies disrupting GRK2-mediated signaling appear cardioprotective [352-354]. GRK2 is upregulated in sepsis, HF, BD and post-ischemia [355-357], and translocation of GRK2 to the mitochondria can influence fatty acid oxidation and ATP production rate [354,358]. The precise effects, however, are still under scrutiny due to the variability in observations, which may be influenced by the physiological setting and cell type. 


\subsubsection{Energetic Imbalance}

An often overlooked and misunderstood factor of adrenergic inotropic support is their energetic cost. In settings where this energetic imbalance is already disrupted in the heart due to IRI (e.g., cardiac surgery, HTx), inotrope support may exacerbate this imbalance, with inoconstrictor agents potentially more detrimental than inodilators. Increased LV afterload, coupled with elevated heart rate following inconstrictor administration significantly increases myocardial oxygen consumption rate, potentially hastening cell death [285]. Under normal circumstances, mitochondrial respiration is stimulated by calcium activation of the Krebs cycle, upregulating NADH production. Intracellular calcium overload, as a consequence of high or prolonged inotrope use, promotes mitochondrial dyscoupling and ATP depletion. Using a sheep model of $24 \mathrm{~h}$ BD followed by orthotopic HTx, our group has observed elevated complex I and reduced complex II-mediated mitochondrial respiration post-HTx. The increase in complex I respiration, however, occurred in the presence of higher electron slip, and did not result in production of a mitochondrial membrane potential greater than controls [unpublished data] [359]. This greater oxygen utilization in the absence of membrane potential generation implies increased ROS and lower ATP production rates. In HF, mitochondrial calcium uptake is impaired, which promotes ROS production, and subsequently potentiates arrhythmias and cardiomyocyte damage [360]. Myocardial metabolic inflexibility is also a common feature in critical illness and in response to high catecholamine exposure [361]. Due to the enhancement of carbohydrate metabolism, $\beta$-oxidation usually declines with an increase in cellular uptake of fatty acids, resulting in uncoupled mitochondrial respiration [362]. Any increase in carbohydrate metabolism will also increase the rate of lactate production, and in the context of poor calcium handling and oxidative stress, may lead to cellular acidosis and apoptosis. Theoretically, increases in glycolytic rate increase the oxygen efficiency of the cell. However, it has been shown in human and animal HF models that carbohydrate oxidation and its contribution to ATP are decreased [361].

\subsection{Myofilament Calcium Sensitisers}

Myofilament calcium sensitizers (e.g., levosimendan, pimobendan, EMD-57033, GCP-48506, omecamtiv mecarbil) increase the affinity of troponin $C$ or actin-myosin to bind calcium, or directly bind to the motor domain of myosin, producing elevations in inotropy and systolic ejection time [284]. Calcium sensitizers were thought to offer several cardioprotective advantages over adrenergic stimulants. Independent of adrenergic stimulants, this group of drugs do not alter calcium handling, chronotropy or blood pressure, and thus do not induce desensitization nor impose energetic compromise. Conversely, myofilament calcium sensitizers are arrhythmogenic and reduce diastole [284].

Evidence thus far on the benefits of using calcium sensitizers in place of adrenergic stimulants has not yet reached a definitive conclusion. Levosimendan reportedly improves cardiac contractility and induces vasodilation without increasing the myocardial oxygen demand [363]. Furthermore, levosimendan appears to influence mitochondrial potassium ATP channels, promotes prosurvival ERK1/2 signaling [364], is anti-inflammatory and anti-apoptotic [365]. Clinical trials and metanalyses have suggested the use of levosimendan for HF reduced the relative risk of mortality, improved hemodynamics, and reduced post-operative inotrope use [284]. Beiras-Fernandez and colleagues showed that post-HTx, a $24 \mathrm{~h}$ infusion $(0.1 \mu \mathrm{g} / \mathrm{kg} / \mathrm{min})$ of levosimendan reduced the inotropic demand and improved ventricular performance [366]. Levosimendan has also been shown to reduce the requirement for high inotrope support and facilitate weaning from V-A ECMO [367], and ameliorate pre-VAD implantation hemodynamic compromise and assist in predicting post-VAD RV failure [368]. However, other clinical trials (LeoPARDS [369], CHEETAH [370], SURVIVE [371] and LEVO-CTS [372]) have found no reduction in patient mortality, with an increased risk of tachyarrhythmias. Studies examining omecamtiv mecarbil (OM) in HF, revealed that although effective at increasing inotropy, OM also reduced diastolic time [284]. This led to myocardial ischemia, elevated plasma troponin and ECG changes, potentially a result of poor perfusion, as diastolic time was reduced in favor of increased systole. Further studies targeting specific plasma concentrations or restraining the maximum 
OM dose have shown improved exercise tolerance and dyspnea relief [284]. Moreover, levosimendan administered in patients who also received prior $\beta$-blocker therapy showed improved short-term outcomes in the SURVIVE trial [371]. These results, similar to adrenergic stimulants, may highlight the complexity of calcium sensitizers to their dose and clinical scenario.

\subsection{Enhancers of Cytosolic $\mathrm{Ca}^{2+}$ Handling}

These drugs have multiple mechanisms of action to improve cytosolic calcium handling and are an active area of research, with ongoing trials currently underway to ascertain their clinical utility [284]. The initial CUPID 1 trial that attempted to restore myocardial SERCA2a expression and activity in HF patients via gene therapy demonstrated safety and potential efficacy [373], leading to the CUPID 2 trial. Unfortunately, the primary outcome of CUPID 2 (time to re-hospitalization) was not improved, with questions rising over the efficacy of the gene delivery [374]. The neutral results of the CUPID2 trial led to suspension of the SERCA-LVAD (NCT00534703), which was assessing AAV1.SERCA2a in HF patients who had received an LVAD, and was targeting weaning of patients from the LVAD.

Nitroxyl reportedly improves myocardial calcium transients and cardiac contraction independent of cAMP/cGMP-mediated pathways [375], and nitroxyl donors have been (CXL-1020) [376] and are currently being (CXL-1427, NCT02157506, NCT02819271) [284] investigated in Phase I and II clinical trials. Here, CXL-1020 improved myocardial function in patients with systolic HF, adult mouse cardiomyocytes, and in in vivo canine models of $\mathrm{HF}$ [376]. Istaroxime inhibits the $\mathrm{Na}^{+} / \mathrm{K}^{+} \mathrm{ATPase}$ and activates SERCA, with resultant beneficial effects on inotropy and lusitropy. In the HORIZON-HF trial, systolic blood pressure, diastolic function and cardiac index were improved with istaroxime treatment (6 $\mathrm{h}$ i.v.) [377], which has led to an ongoing trial in patients with acute decompensated heart failure (NCT02617446). Evidently, several drugs acting to improve cytosolic $\mathrm{Ca}^{2+}$ handling while avoiding cardiovascular compromise and energetic imbalances show promise in HF settings over traditional inotropic agents. Larger clinical trials are necessary to solidify their cardioprotective effects and clinical utility in critically ill cardiac patients that could benefit from an effective therapy. This is a common feature of most inotropes and vasopressors, where clinical need has circumvented empirical-based investigation into appropriate administration. Significant future research is necessary in order to determine the correct inotrope, vasopressor or combination for a particular disease state at a particular dose. This will help to delineate the balance between cardioprotection and myocardial compromise often observed during hemodynamic management.

\section{Conclusions}

Cardiovascular disease and HF continue to expand and are currently the number one cause of global mortality, despite significant advances in technology and therapeutic strategies targeting the associated cardiac dysfunction. While some treatment options are beneficial and essential for patient survival and restoration of cardiac function, their use comes at a physiological cost that can worsen both short- and long-term outcomes. Evidently, this cohort of critically ill cardiac patients would significantly benefit from complimentary and effective cardioprotective strategies. However, in the context of these relevant surgical interventions (MCS and HTx), important factors inherent to these treatments must be carefully considered to achieve clinical efficacy.

Author Contributions: Conceptualization, L.E.S. and N.B.; writing-original draft preparation, L.E.S., N.B., M.A.W., J.Y.S.; writing-review and editing, L.E.S., N.B., M.A.W., J.Y.S., J.F.F.

Funding: This research was funded by the University of Queensland.

Acknowledgments: N.B. and L.E.S. are both recipients of a Prince Charles Hospital Foundation Postdoctoral Fellowship. M.A.W. is the recipient of a Griffith University Postgraduate Research Scholarship. J.F.F. is the recipient of an Office of Health and Medical Research Fellowship from the Queensland Government. The authors are supported by the University of Queensland, the Prince Charles Hospital Foundation, the Metro North Hospital and Health Service and the National Health and Medical Research Council.

Conflicts of Interest: The authors declare no conflict of interest. 


\section{Abbreviations}

$\begin{array}{ll}\text { HF } & \text { Heart Failure } \\ \text { HTx } & \text { Heart Transplant } \\ \text { BD } & \text { Brain dead } \\ \text { PGD } & \text { Primary graft dysfunction } \\ \text { IRI } & \text { Ischemia-reperfusion injury } \\ \text { IR } & \text { Ischemia-reperfusion } \\ \text { MCS } & \text { Mechanical circulatory support } \\ \text { VAD } & \text { Ventricular assist device } \\ \text { ECMO } & \text { Extracorporeal membrane oxygenation } \\ \text { V-A } & \text { Veno-arterial } \\ \text { PVAD } & \text { Percutaneous ventricular assist device } \\ \text { IABP } & \text { Intra-aortic balloon pump } \\ \text { LV } & \text { Left ventricle } \\ \text { RV } & \text { Right ventricle } \\ \text { RVF } & \text { Right ventricular failure } \\ \text { AMI } & \text { Acute myocardial infarction } \\ \text { PCI } & \text { Percutaneous coronary intervention } \\ \text { ICT } & \text { Intracardiac thrombosis } \\ \text { VA } & \text { Ventricular arrhythmia } \\ \text { AI } & \text { Aortic insufficiency } \\ \text { MSC } & \text { Mesenchymal stromal cells } \\ \text { MPC } & \text { Mesenchymal precursor cells } \\ \text { TAC } & \text { Tacrolimus (TAC) } \\ \text { CsA } & \text { Cyclosporine A } \\ \text { MMF } & \text { Mycophenolate mofetil } \\ \text { AZA } & \text { Azathioprine } \\ \text { Treg } & \text { Regulatory T cells } \\ \text { CRS } & \text { Cytokine release syndrome } \\ \text { GPCR } & \text { G protein-coupled receptors } \\ \text { ATG } & \text { Anti-thymocyte globulin } \\ \text { LMWH } & \text { Low molecular weight derivatives } \\ \text { HLA-G } & \text { Human leukocyte antigen-G } \\ \text { PGD } & \text { Prostaglandin D } \\ \text { PGD2 } & \text { Prostaglandin D2 } \\ \text { MP } & \text { Methylprednisolone } \\ \beta-A R ~ & \text { B-adrenoceptors } \\ \alpha-A R & \alpha \text {-adrenoceptor } \\ \text { GC } & \text { Glucocorticoids } \\ & \end{array}$

\section{References}

1. Ritchie, H.; Roser, M. Causes of Death. Available online: OurWorldInData.org (accessed on 15 April 2019).

2. Ponikowski, P.; Anker, S.D.; AlHabib, K.F.; Cowie, M.R.; Force, T.L.; Hu, S.; Jaarsma, T.; Krum, H.; Rastogi, V.; Rohde, L.E.; et al. Heart failure: Preventing disease and death worldwide. ESC Heart Fail. 2014, 1, 4-25. [CrossRef] [PubMed]

3. Benjamin, E.J.; Virani, S.S.; Callaway, C.W.; Chamberlain, A.M.; Chang, A.R.; Cheng, S.; Chiuve, S.E.; Cushman, M.; Delling, F.N.; Deo, R.; et al. Heart Disease and Stroke Statistics-2018 Update: A Report from the American Heart Association. Circulation 2018, 137, e67-e492. [CrossRef] [PubMed]

4. Heidenreich, P.A.; Albert, N.M.; Allen, L.A.; Bluemke, D.A.; Butler, J.; Fonarow, G.C.; Ikonomidis, J.S.; Khavjou, O.; Konstam, M.A.; Maddox, T.M.; et al. Forecasting the Impact of Heart Failure in the United States A Policy Statement from the American Heart Association. Circ. Heart Fail. 2013, 6, 606-619. [CrossRef] [PubMed]

5. Braunwald, E. Shattuck lecture-Cardiovascular medicine at the turn of the millennium: Triumphs, concerns, and opportunities. N. Engl. J. Med. 1997, 337, 1360-1369. [CrossRef] [PubMed] 
6. Merlo, M.; Pivetta, A.; Pinamonti, B.; Stolfo, D.; Zecchin, M.; Barbati, G.; Di Lenarda, A.; Sinagra, G. Long-term prognostic impact of therapeutic strategies in patients with idiopathic dilated cardiomyopathy: Changing mortality over the last 30 years. Eur. J. Heart Fail. 2014, 16, 317-324. [CrossRef] [PubMed]

7. Dunlay, S.M.; Redfield, M.M.; Weston, S.A.; Therneau, T.M.; Hall Long, K.; Shah, N.D.; Roger, V.L. Hospitalizations after heart failure diagnosis a community perspective. J. Am. Coll. Cardiol. 2009, 54, 1695-1702. [CrossRef]

8. Gheorghiade, M.; Vaduganathan, M.; Fonarow, G.C.; Bonow, R.O. Rehospitalization for heart failure: Problems and perspectives. J. Am. Coll. Cardiol. 2013, 61, 391-403. [CrossRef] [PubMed]

9. Sanada, S.; Komuro, I.; Kitakaze, M. Pathophysiology of myocardial reperfusion injury: Preconditioning, postconditioning, and translational aspects of protective measures. Am. J. Physiol. Heart Circ. Physiol. 2011, 301, H1723-H1741. [CrossRef]

10. Jennings, R.B.; Reimer, K.A. The cell biology of acute myocardial ischemia. Annu. Rev. Med. 1991, 42, 225-246. [CrossRef]

11. Yellon, D.M.; Hausenloy, D.J. Myocardial reperfusion injury. N. Engl. J. Med. 2007, 357, 1121-1135. [CrossRef]

12. Bolli, R.; Becker, L.; Gross, G.; Mentzer Jr, R.; Balshaw, D.; Lathrop, D.A. Myocardial protection at a crossroads: The need for translation into clinical therapy. Circ. Res. 2004, 95, 125-134. [CrossRef]

13. Heusch, G. Cardioprotection: Chances and challenges of its translation to the clinic. Lancet 2013, 381, 166-175. [CrossRef]

14. Heusch, G. Critical Issues for the Translation of Cardioprotection. Circ. Res. 2017, 120, 1477-1486. [CrossRef]

15. Rosenberg, J.H.; Werner, J.H.; Moulton, M.J.; Agrawal, D.K. Current Modalities and Mechanisms Underlying Cardioprotection by Ischemic Conditioning. J. Cardiovasc. Transl. Res. 2018, 11, 292-307. [CrossRef]

16. Peart, J.N.; Headrick, J.P. Clinical cardioprotection and the value of conditioning responses. Am. J. Physiol. Heart Circ. Physiol. 2009, 296, H1705-H1720. [CrossRef]

17. See Hoe, L.; Patel, H.H.; Peart, J.N. Delta Opioid Receptors and Cardioprotection. Handb. Exp. Pharmacol. 2018, 247, 301-334.

18. Gregory, S.D.; Stevens, M.C.; Pauls, J.P.; Schummy, E.; Diab, S.; Thomson, B.; Anderson, B.; Tansley, G.; Salamonsen, R.; Fraser, J.F.; et al. In Vivo Evaluation of Active and Passive Physiological Control Systems for Rotary Left and Right Ventricular Assist Devices. Artif. Organs 2016, 40, 894-903. [CrossRef]

19. Passmore, M.R.; Fung, Y.L.; Simonova, G.; Foley, S.R.; Dunster, K.R.; Diab, S.D.; Tung, J.P.; Minchinton, R.M.; McDonald, C.I.; Anstey, C.M.; et al. Inflammation and lung injury in an ovine model of extracorporeal membrane oxygenation support. Am. J. Physiol. Lung Cell. Mol. Physiol. 2016, 311, L1202-L1212. [CrossRef]

20. See Hoe, L.E.; Engkilde-Pedersen, S.; Obonyo, N.G.; Wells, M.A.; Boon, C.; Bartnikowski, N.; Passmore, M.; McDonald, C.; Black, D.; Molenaar, P.; et al. Development of an Ovine Model of Heart Transplantation Following 24-Hour Brain Stem Death. Heart Lung Circ. 2018, 27, S92. [CrossRef]

21. Habal, M.V.; Garan, A.R. Long-term management of end-stage heart failure. Best Pract. Res. Clin. Anaesthesiol. 2017, 31, 153-166. [CrossRef]

22. Chaudhry, S.P.; Stewart, G.C. Advanced Heart Failure: Prevalence, Natural History, and Prognosis. Heart Fail. Clin. 2016, 12, 323-333. [CrossRef]

23. Dick, S.A.; Epelman, S. Chronic Heart Failure and Inflammation: What Do We Really Know? Circ. Res. 2016, 119, 159-176. [CrossRef]

24. Atherton, J.J.; Sindone, A.; De Pasquale, C.G.; Driscoll, A.; MacDonald, P.S.; Hopper, I.; Kistler, P.; Briffa, T.G.; Wong, J.; Abhayaratna, W.P.; et al. National Heart Foundation of Australia and Cardiac Society of Australia and New Zealand: Australian clinical guidelines for the management of heart failure 2018. Med. J. Aust. 2018, 209, 363-369. [CrossRef]

25. Kong, C.H.; Lin, X.Y.; Woo, C.C.; Wong, H.C.; Lee, C.N.; Richards, A.M.; Sorokin, V.A. Characteristics of aortic wall extracellular matrix in patients with acute myocardial infarction: Tissue microarray detection of collagen I, collagen III and elastin levels. Interact. Cardiovasc. Thorac. Surg. 2013, 16, 11-15. [CrossRef]

26. See Hoe, L.E.; May, L.T.; Headrick, J.P.; Peart, J.N. Sarcolemmal dependence of cardiac protection and stress-resistance: Roles in aged or diseased hearts. Br. J. Pharmacol. 2016, 173, 2966-2991. [CrossRef]

27. See Hoe, L.E.; Schilling, J.M.; Tarbit, E.; Kiessling, C.J.; Busija, A.R.; Niesman, I.R.; Du Toit, E.; Ashton, K.J.; Roth, D.M.; Headrick, J.P.; et al. Sarcolemmal cholesterol and caveolin-3 dependence of cardiac function, ischemic tolerance, and opioidergic cardioprotection. Am. J. Physiol. Heart Circ. Physiol. 2014, 307, H895-H903. [CrossRef] 
28. De Carvalho, L.P.; Tan, S.H.; Ow, G.S.; Tang, Z.; Ching, J.; Kovalik, J.P.; Poh, S.C.; Chin, C.T.; Richards, A.M.; Martinez, E.C.; et al. Plasma Ceramides as Prognostic Biomarkers and Their Arterial and Myocardial Tissue Correlates in Acute Myocardial Infarction. JACC Basic Transl. Sci. 2018, 3, 163-175. [CrossRef]

29. Wongsurawat, T.; Woo, C.C.; Giannakakis, A.; Lin, X.Y.; Cheow, E.S.H.; Lee, C.N.; Richards, M.; Sze, S.K.; Nookaew, I.; Kuznetsov, V.A.; et al. Distinctive molecular signature and activated signaling pathways in aortic smooth muscle cells of patients with myocardial infarction. Atherosclerosis 2018, 271, 237-244. [CrossRef]

30. Derda, A.A.; Woo, C.C.; Wongsurawat, T.; Richards, M.; Lee, C.N.; Kofidis, T.; Kuznetsov, V.A.; Sorokin, V.A. Gene expression profile analysis of aortic vascular smooth muscle cells reveals upregulation of cadherin genes in myocardial infarction patients. Physiol. Genom. 2018, 50, 648-657. [CrossRef]

31. Feldman, D.; Pamboukian, S.V.; Teuteberg, J.J. The 2013 International Society for Heart and Lung Transplantation Guidelines for mechanical circulatory support: Executive summary. J. Heart Lung Transplant. 2013, 32, 157-187. [CrossRef]

32. Kirklin James, K.; Naftel David, C. Mechanical Circulatory Support. Circ. Heart Fail. 2008, 1, $200-205$. [CrossRef]

33. Shekar, K.; Gregory, S.D.; Fraser, J.F. Mechanical circulatory support in the new era: An overview. Crit. Care 2016, 20, 66. [CrossRef]

34. Paliwal, S.; Kakkar, A.; Sharma, R.; Airan, B.; Mohanty, S. Differential reduction of reactive oxygen species by human tissuespecific mesenchymal stem cells from different donors under oxidative stress. J. Biosci. 2017, 42, 373-382. [CrossRef]

35. Reynolds, H.R.; Hochman, J.S. Cardiogenic shock: Current concepts and improving outcomes. Circulation 2008, 117, 686-697. [CrossRef]

36. Thiele, H.; Ohman, E.M.; Desch, S.; Eitel, I.; de Waha, S. Management of cardiogenic shock. Eur. Heart J. 2015, 36, 1223-1230. [CrossRef]

37. Thiele, H.; Zeymer, U.; Neumann, F.J. Intraaortic balloon support for myocardial infarction with cardiogenic shock. N. Engl. J. Med. 2012, 367, 1287-1296. [CrossRef]

38. Lauten, E.A.; Engström, W.A.; Jung, F.C.; Empen, G.K.; Erne, P.S.P.; Cook, R.S.; Windecker, R.S.; Bergmann, R.M.; Klingenberg, R.R.; Lüscher, R.T.; et al. Percutaneous Left-Ventricular Support with the Impella-2.5-Assist Device in Acute Cardiogenic Shock: Results of the Impella-EUROSHOCK-Registry. Circ. Heart Fail. 2013, 6, 23-30. [CrossRef]

39. Myat, A.; Patel, N.; Tehrani, S.; Banning, A.P.; Redwood, S.R.; Bhatt, D.L. Percutaneous Circulatory Assist Devices for High-Risk Coronary Intervention. JACC Cardiovasc. Interv. 2015, 8, 229-244. [CrossRef]

40. O'Neill William, W.; Kleiman Neal, S.; Moses, J.; Henriques Jose, P.S.; Dixon, S.; Massaro, J.; Palacios, I.; Maini, B.; Mulukutla, S.; Džavík, V.; et al. A Prospective, Randomized Clinical Trial of Hemodynamic Support with Impella 2.5 Versus Intra-Aortic Balloon Pump in Patients Undergoing High-Risk Percutaneous Coronary Intervention. Circulation 2012, 126, 1717-1727.

41. Takayama, H.; Truby, L.; Takeda, K.; Naka, Y. Short-Term Ventricular Assist Devices (Implantable and Percutaneous). Curr. Surg. Rep. 2014, 2, 58. [CrossRef]

42. Sorokin, V.; MacLaren, G.; Vidanapathirana, P.C.; Delnoij, T.; Lorusso, R. Choosing the appropriate configuration and cannulation strategies for extracorporeal membrane oxygenation: The potential dynamic process of organ support and importance of hybrid modes. Eur. J. Heart Fail. 2017, 19 (Suppl. 2), 75-83. [CrossRef]

43. Peart, J.N.; Pepe, S.; Reichelt, M.E.; Beckett, N.; See Hoe, L.; Ozberk, V.; Niesman, I.R.; Patel, H.H.; Headrick, J.P. Dysfunctional survival-signaling and stress-intolerance in aged murine and human myocardium. Exp. Gerontol. 2014, 50, 72-81. [CrossRef]

44. Vakayil, V.; Thompson, D.A.; Sundin, A.; Chandrashekar, M.; Harmon, J.V., Jr.; Brunsvold, M.E. Indicators of Mortality for Patients on Veno-Arterial Extracorporeal Membrane Oxygenation (ECMO): A Single Center Experience. J. Am. Coll. Surg. 2017, 225, e74-e75. [CrossRef]

45. Wang, L.; Yang, F.; Wang, X.; Xie, H.; Fan, E.; Ogino, M.; Brodie, D.; Wang, H.; Hou, X. Predicting mortality in patients undergoing VA-ECMO after coronary artery bypass grafting: The REMEMBER score. Crit. Care 2019, 23, 11. [CrossRef]

46. Lawson, W.E.; Koo, M. Percutaneous Ventricular Assist Devices and ECMO in the Management of Acute Decompensated Heart Failure. Clin. Med. Insights Cardiol. 2015, 9 (Suppl. 1), 41-48. [CrossRef] 
47. Gilotra, N.A.; Stevens, G.R. Temporary mechanical circulatory support: A review of the options, indications, and outcomes. Clin. Med. Insights Cardiol. 2015, 8 (Suppl. 1), 75-85. [CrossRef]

48. Burkhoff, D.; Cohen, H.; Brunckhorst, C.; O’Neill, W.W. A randomized multicenter clinical study to evaluate the safety and efficacy of the TandemHeart percutaneous ventricular assist device versus conventional therapy with intraaortic balloon pumping for treatment of cardiogenic shock. Am. Heart J. 2006, 152, 469.e1-469.e8. [CrossRef]

49. Thiele, H.; Sick, P.; Boudriot, E.; Diederich, K.W.; Hambrecht, R.; Niebauer, J.; Schuler, G. Randomized comparison of intra-aortic balloon support with a percutaneous left ventricular assist device in patients with revascularized acute myocardial infarction complicated by cardiogenic shock. Eur. Heart J. 2005, 26, 1276-1283. [CrossRef]

50. Miller, M.A.; Dukkipati, S.R.; Mittnacht, A.J.; Chinitz, J.S.; Belliveau, L.; Koruth, J.S.; Gomes, J.A.; d'Avila, A.; Reddy, V.Y. Activation and Entrainment Mapping of Hemodynamically Unstable Ventricular Tachycardia Using a Percutaneous Left Ventricular Assist Device. J. Am. Coll. Cardiol. 2011, 58, 1363-1371. [CrossRef]

51. Seyfarth, M.; Sibbing, D.; Bauer, I.; Fröhlich, G.; Bott-Flügel, L.; Byrne, R.; Dirschinger, J.; Kastrati, A.; Schömig, A. A Randomized Clinical Trial to Evaluate the Safety and Efficacy of a Percutaneous Left Ventricular Assist Device Versus Intra-Aortic Balloon Pumping for Treatment of Cardiogenic Shock Caused by Myocardial Infarction. J. Am. Coll. Cardiol. 2008, 52, 1584-1588. [CrossRef]

52. Schrage, B.; Ibrahim, K.; Loehn, T.; Werner, N.; Sinning, J.M.; Pappalardo, F.; Pieri, M.; Skurk, C.; Lauten, A.; Landmesser, U.; et al. Impella Support for Acute Myocardial Infarction Complicated by Cardiogenic Shock. Circulation 2019, 139, 1249-1258. [CrossRef]

53. Kapur, N.K.; Qiao, X.; Paruchuri, V.; Morine, K.J.; Syed, W.; Dow, S.; Shah, N.; Pandian, N.; Karas, R.H. Mechanical Pre-Conditioning with Acute Circulatory Support Before Reperfusion Limits Infarct Size in Acute Myocardial Infarction. JACC Heart Fail. 2015, 3, 873-882. [CrossRef]

54. Myers, T. Temporary Ventricular Assist Devices in the Intensive Care Unit as a Bridge to Decision. $A A C N$ Adv. Crit. Care 2012, 23, 55-68. [CrossRef]

55. Nicolini, F.; Gherli, T. Alternatives to transplantation in the surgical therapy for heart failure. Eur. J. CardioThoracic Surg. 2009, 35, 214-228. [CrossRef]

56. Slaughter, M.S.; Rogers, J.G.; Milano, C.A.; Russell, S.D.; Conte, J.V.; Feldman, D.; Sun, B.; Tatooles, A.J.; Delgado, R.M.; Long, J.W.; et al. Advanced Heart Failure Treated with Continuous-Flow Left Ventricular Assist Device. N. Engl. J. Med. 2009, 361, 2241-2251. [CrossRef]

57. Dandel, M.; Hetzer, R. Recovery of failing hearts by mechanical unloading: Pathophysiologic insights and clinical relevance. Am. Heart J. 2018, 206, 30-50. [CrossRef]

58. Kirklin, J.K.; Pagani, F.D.; Kormos, R.L.; Stevenson, L.W.; Blume, E.D.; Myers, S.L.; Miller, M.A.; Baldwin, J.T.; Young, J.B.; Naftel, D.C. Eighth annual INTERMACS report: Special focus on framing the impact of adverse events. J. Hear. Lung Transplant. 2017, 36, 1080-1086. [CrossRef]

59. Dandel, M.; Hetzer, R. Myocardial recovery during mechanical circulatory support: Long-term outcome and elective ventricular assist device implantation to promote recovery as a treatment goal. Heart Lung Vessel. 2015, 7, 289.

60. Kirklin, J.K.; Naftel, D.C.; Pagani, F.D. Sixth INTERMACS annual report: A 10,000-patient database. J. Heart Lung Transplant. 2014, 33, 555-564. [CrossRef]

61. Drakos, S.G.; Kfoury, A.G.; Stehlik, J.; Selzman, C.H.; Reid, B.B.; Terrovitis, J.V.; Nanas, J.N.; Li, D.Y. Bridge to recovery: Understanding the disconnect between clinical and biological outcomes. Circulation 2012, 126, 230-241. [CrossRef]

62. Mehra, M.R.; Goldstein, D.J.; Uriel, N.; Cleveland, J.C.; Yuzefpolskaya, M.; Salerno, C.; Walsh, M.N.; Milano, C.A.; Patel, C.B.; Ewald, G.A.; et al. Two-Year Outcomes with a Magnetically Levitated Cardiac Pump in Heart Failure. N. Engl. J. Med. 2018, 378, 1386-1395. [CrossRef]

63. Thomas, J.; Kostousov, V.; Teruya, J. Bleeding and Thrombotic Complications in the Use of Extracorporeal Membrane Oxygenation. Semin. Thromb. Hemost. 2018, 44, 20-29. [CrossRef]

64. Dalton, H.J.; Reeder, R.; Garcia-Filion, P.; Holubkov, R.; Berg, R.A.; Zuppa, A.; Moler, F.W.; Shanley, T.; Pollack, M.M.; Newth, C.; et al. Factors Associated with Bleeding and Thrombosis in Children Receiving Extracorporeal Membrane Oxygenation. Am. J. Respir. Crit. Care Med. 2017, 196, 762-771. [CrossRef]

65. Mehta, H.; Eisen, H.; Cleveland, J.C. Indications and Complications for VA-ECMO for Cardiac Failure; American College of Cardiology Perspectives and Analysis: Washington, DC, USA, 2015. 
66. Alhussein, M.; Moayedi, Y.; Posada, J.D.; Ross, H.; Hickey, E.; Rao, V.; Billia, F. Ventricular Thrombosis Post-Venoarterial Extracorporeal Membrane Oxygenation. Circ. Heart Fail. 2017, 10, e003757. [CrossRef]

67. Makdisi, G.; Hashmi, Z.A.; Wozniak, T.C.; Wang, I.W. Left ventricular thrombus associated with arteriovenous extra corporeal membrane oxygenation. J. Thorac. Dis. 2015, 7, E552-E554.

68. Williams, B.; Bernstein, W. Review of Venoarterial Extracorporeal Membrane Oxygenation and Development of Intracardiac Thrombosis in Adult Cardiothoracic Patients. J. Extra Corpor. Technol. 2016, 48, 162-167.

69. Weber, C.; Deppe, A.C.; Sabashnikov, A.; Slottosch, I.; Kuhn, E.; Eghbalzadeh, K.; Scherner, M.; Choi, Y.H.; Madershahian, N.; Wahlers, T. Left ventricular thrombus formation in patients undergoing femoral veno-arterial extracorporeal membrane oxygenation. Perfusion 2018, 33, 283-288. [CrossRef]

70. Bhat, A.G.; Golchin, A.; Pasupula, D.K.; Hernandez-Montfort, J.A. Right Sided Intracardiac Thrombosis during Veno-Arterial Extracorporeal Membrane Oxygenation: A Case Report and Literature Review. Case Rep. Crit. Care 2019, 2019, 8594681. [CrossRef]

71. Riahi, M.; Baruteau, A.E. Left ventricular distention under venoarterial extracorporeal membrane oxygenation support: When should we consider percutaneous left heart decompression? J. Thorac. Dis. 2017, 9, 4919-4921. [CrossRef]

72. Meani, P.; Pappalardo, F. The step forward for VA ECMO: Left ventricular unloading! J. Thorac. Dis. 2017, 9, 4149-4151. [CrossRef]

73. Donker, D.W.; Brodie, D.; Henriques, J.P.S.; Broome, M. Left ventricular unloading during veno-arterial ECMO: A review of percutaneous and surgical unloading interventions. Perfusion 2019, 34, 98-105. [CrossRef]

74. Conrad, S.A. Persistent hypoxemia on ECMO. Qatar Med. J. 2017, 1, 18. [CrossRef]

75. Cove, M.E. Disrupting differential hypoxia in peripheral veno-arterial extracorporeal membrane oxygenation. Crit. Care 2015, 19, 280. [CrossRef]

76. Hou, X.; Yang, X.; Du, Z.; Xing, J.; Li, H.; Jiang, C.; Wang, J.; Xing, Z.; Li, S.; Li, X.; et al. Superior vena cava drainage improves upper body oxygenation during veno-arterial extracorporeal membrane oxygenation in sheep. Crit. Care 2015, 19, 68. [CrossRef]

77. Sidebotham, D. Troubleshooting adult ECMO. J. Extra Corpor. Technol. 2011, 43, P27-P32.

78. Millar, J.E.; Fanning, J.P.; McDonald, C.I.; McAuley, D.F.; Fraser, J.F. The inflammatory response to extracorporeal membrane oxygenation (ECMO): A review of the pathophysiology. Crit. Care 2016, 20, 387. [CrossRef]

79. Hayes, R.A.; Shekar, K.; Fraser, J.F. Is hyperoxaemia helping or hurting patients during extracorporeal membrane oxygenation? Review of a complex problem. Perfusion 2013, 28, 184-193. [CrossRef]

80. McDonald, C.I.; Fraser, J.F.; Coombes, J.S.; Fung, Y.L. Oxidative stress during extracorporeal circulation. Eur. J. Cardio Thorac. Surg. 2014, 46, 937-943. [CrossRef]

81. Gregoric, I.D.; Bruckner, B.A.; Jacob, L.; Loyalka, P.; Kar, B.; La Francesca, S.; Myers, T.; Frazier, O.H. Techniques and Complications of TandemHeart Ventricular Assist Device Insertion During Cardiac Procedures. ASAIO J. 2009, 55, 251-254. [CrossRef]

82. De Souza, C.F.; De Souza Brito, F.; De Lima, V.C.; De Camargo Carvalho, A.C. Percutaneous Mechanical Assistance for the Failing Heart. J. Interv. Cardiol. 2010, 23, 195-202. [CrossRef]

83. Kirklin, J.K.; Naftel, D.C.; Pagani, F.D.; Kormos, R.L.; Stevenson, L.W.; Blume, E.D.; Myers, S.L.; Miller, M.A.; Baldwin, J.T.; Young, J.B. Seventh INTERMACS annual report: 15,000 patients and counting. J. Hear. Lung Transplant. 2015, 34, 1495-1504. [CrossRef]

84. Stewart, C.G.; Givertz, M.M. Mechanical Circulatory Support for Advanced Heart Failure: Patients and Technology in Evolution. Circulation 2012, 125, 1304-1315. [CrossRef]

85. Ziv, O.; Dizon, J.; Thosani, A.; Naka, Y.; Magnano, A.R.; Garan, H. Effects of Left Ventricular Assist Device Therapy on Ventricular Arrhythmias. J. Am. Coll. Cardiol. 2005, 45, 1428-1434. [CrossRef]

86. Refaat, M.; Chemaly, E.; Lebeche, D.; Gwathmey, J.K.; Hajjar, R.J. Ventricular Arrhythmias after Left Ventricular Assist Device Implantation. Pacing Clin. Electrophysiol. 2008, 31, 1246-1252. [CrossRef]

87. Grzywacz, F.W.; Piacentino, V., III; Marble, J.; Bozorgnia, B.; Gaughan, J.P.; Rothman, S.A.; Margulies, K.B. Effect of Acute Unloading Via Head-Up Tilt on QTc Prolongation in Patients with Ischemic or Non-Ischemic Cardiomyopathy. Am. J. Cardiol. 2006, 97, 412-415. [CrossRef]

88. Oswald, H.; Schultz-Wildelau, C.; Gardiwal, A.; Lüsebrink, U.; König, T.; Meyer, A.; Duncker, D.; Pichlmaier, M.A.; Klein, G.; Strüber, M. Implantable defibrillator therapy for ventricular tachyarrhythmia in left ventricular assist device patients. Eur. J. Fail. 2010, 12, 593-599. [CrossRef] 
89. Aggarwal, A.; Raghuvir, R.; Eryazici, P.; Macaluso, G.; Sharma, P.; Blair, C.; Tatooles, A.J.; Pappas, P.S.; Bhat, G. The Development of Aortic Insufficiency in Continuous-Flow Left Ventricular Assist Device-Supported Patients. Ann. Thorac. Surg. 2013, 95, 493-498. [CrossRef]

90. Deo, S.V.; Sharma, V.; Cho, Y.H.; Shah, I.K.; Park, S.J. De Novo Aortic Insufficiency During Long-Term Support on a Left Ventricular Assist Device: A Systematic Review and Meta-Analysis. ASAIO J. 2014, 60, 183-188. [CrossRef]

91. May-Newman, K.; Hillen, B.; Dembitsky, W. Effect of Left Ventricular Assist Device Outflow Conduit Anastomosis Location on Flow Patterns in the Native Aorta. ASAIO J. 2006, 52, 132-139. [CrossRef]

92. Cowger, J.; Pagani, F.D.; Haft, J.W.; Romano, M.A.; Aaronson, K.D.; Kolias, T.J. The development of aortic insufficiency in left ventricular assist device-supported patients. Circ. Heart Fail. 2010, 3, 668-674. [CrossRef]

93. Drakos, S.; Janicki, L.; Horne, B.D.; Kfoury, A.; Reid, B.B.; Clayson, S.; Horton, K.; Haddad, F.; Li, D.Y.; Renlund, D.G.; et al. Risk Factors Predictive of Right Ventricular Failure After Left Ventricular Assist Device Implantation. Am. J. Cardiol. 2010, 105, 1030-1035. [CrossRef]

94. Lampert, B.C.; Teuteberg, J.J. Right ventricular failure after left ventricular assist devices. J. Heart Lung Transplant. 2015, 34, 1123-1130. [CrossRef]

95. Argiriou, M.; Kolokotron, S.M.; Sakellaridis, T.; Argiriou, O.; Charitos, C.; Zarogoulidis, P.; Katsikogiannis, N.; Kougioumtzi, I.; Machairiotis, N.; Tsiouda, T.; et al. Right heart failure post left ventricular assist device implantation. J. Thorac. Dis. 2014, 6, S52-S59.

96. Hayek, S.; Sims Daniel, B.; Markham David, W.; Butler, J.; Kalogeropoulos Andreas, P. Assessment of Right Ventricular Function in Left Ventricular Assist Device Candidates. Circ. Cardiovasc. Imaging 2014, 7, 379-389. [CrossRef]

97. Turner, K.R. Right Ventricular Failure After Left Ventricular Assist Device Placement-The Beginning of the End or Just Another Challenge? J. Cardiothorac. Vasc. Anesth. 2019, 33, 1105-1121. [CrossRef]

98. Deschka, H.; Holthaus, A.J.; Sindermann, J.R.; Welp, H.; Schlarb, D.; Monsefi, N.; Martens, S.; Scherer, M. Can Perioperative Right Ventricular Support Prevent Postoperative Right Heart Failure in Patients with Biventricular Dysfunction Undergoing Left Ventricular Assist Device Implantation? J. Cardiothorac. Vasc. Anesth. 2016, 30, 619-626. [CrossRef]

99. Dell'Italia, L.J. Anatomy and Physiology of the Right Ventricle. Cardiol. Clin. 2012, 30, 167-187. [CrossRef]

100. Topilsky, Y.; Hasin, T.; Oh Jae, K.; Borgeson Daniel, D.; Boilson Barry, A.; Schirger John, A.; Clavell Alfredo, L.; Frantz Robert, P.; Tsutsui, R.; Liu, M.; et al. Echocardiographic Variables After Left Ventricular Assist Device Implantation Associated with Adverse Outcome. Circ. Cardiovasc. Imaging 2011, 4, 648-661. [CrossRef]

101. Stone, G.W.; Selker, H.P.; Thiele, H.; Patel, M.R.; Udelson, J.E.; Ohman, E.M.; Maehara, A.; Eitel, I.; Granger, C.B.; Jenkins, P.L.; et al. Relationship Between Infarct Size and Outcomes Following Primary PCI: Patient-Level Analysis from 10 Randomized Trials. J. Am. Coll. Cardiol. 2016, 67, 1674-1683. [CrossRef]

102. Curran, J.; Burkhoff, D.; Kloner, R.A. Beyond Reperfusion: Acute Ventricular Unloading and Cardioprotection During Myocardial Infarction. J. Cardiovasc. Transl. Res. 2019, 12, 95-106. [CrossRef]

103. Uriel, N.; Sayer, G.; Annamalai, S.; Kapur, N.K.; Burkhoff, D. Mechanical Unloading in Heart Failure. J. Am. Coll. Cardiol. 2018, 72, 569-580. [CrossRef]

104. Meyns, B.; Stolinski, J.; Leunens, V.; Verbeken, E.; Flameng, W. Left ventricular support by CatheterMountedaxial flow pump reduces infarct size. J. Am. Coll. Cardiol. 2003, 41, 1087-1095. [CrossRef]

105. Achour, H.; Boccalandro, F.; Felli, P.; Amirian, J.; Uthman, M.; Buja, M.; Smalling, R.W. Mechanical left ventricular unloading prior to reperfusion reduces infarct size in a canine infarction model. Catheter. Cardiovasc. Interv. 2005, 64, 182-192. [CrossRef] [PubMed]

106. Tamareille, S.; Achour, H.; Amirian, J.; Felli, P.; Bick, R.J.; Poindexter, B.; Geng, Y.J.; Barry, W.H.; Smalling, R.W. Left ventricular unloading before reperfusion reduces endothelin-1 release and calcium overload in porcine myocardial infarction. J. Thorac. Cardiovasc. Surg. 2008, 136, 343-351. [CrossRef]

107. Kapur Navin, K.; Paruchuri, V.; Urbano-Morales Jose, A.; Mackey Emily, E.; Daly Gerard, H.; Qiao, X.; Pandian, N.; Perides, G.; Karas Richard, H. Mechanically Unloading the Left Ventricle Before Coronary Reperfusion Reduces Left Ventricular Wall Stress and Myocardial Infarct Size. Circulation 2013, 128, 328-336. [CrossRef] [PubMed]

108. Esposito, M.L.; Zhang, Y.; Qiao, X.; Reyelt, L.; Paruchuri, V.; Schnitzler, G.R.; Morine, K.J.; Annamalai, S.K.; Bogins, C.; Natov, P.S.; et al. Left Ventricular Unloading Before Reperfusion Promotes Functional Recovery After Acute Myocardial Infarction. J. Am. Coll. Cardiol. 2018, 72, 501-514. [CrossRef] 
109. O'Neill, W.W.; Schreiber, T.; Wohns, D.H.W.; Rihal, C.; Naidu, S.S.; Civitello, A.B.; Dixon, S.R.; Massaro, J.M.; Maini, B.; Ohman, E.M. The Current Use of Impella 2.5 in Acute Myocardial Infarction Complicated by Cardiogenic Shock: Results from the USpella Registry. J. Interv. Cardiol. 2014, 27, 1-11. [CrossRef]

110. Basir, M.B.; Schreiber, T.L.; Grines, C.L.; Dixon, S.R.; Moses, J.W.; Maini, B.S.; Khandelwal, A.K.; Ohman, E.M.; O'Neill, W.W.; Dixon, S.F. Effect of Early Initiation of Mechanical Circulatory Support on Survival in Cardiogenic Shock. Am. J. Cardiol. 2017, 119, 845-851. [CrossRef]

111. Russo, J.J.; Aleksova, N.; Pitcher, I.; Couture, E.; Parlow, S.; Faraz, M.; Visintini, S.; Simard, T.; Di Santo, P.; Mathew, R.; et al. Left Ventricular Unloading During Extracorporeal Membrane Oxygenation in Patients with Cardiogenic Shock. J. Am. Coll. Cardiol. 2019, 73, 654-662. [CrossRef]

112. Gass, A.; Palaniswamy, C.; Aronow, W.S.; Kolte, D.; Khera, S.; Ahmad, H.; Cuomo, L.J.; Timmermans, R.; Cohen, M.; Tang, G.H.; et al. Peripheral venoarterial extracorporeal membrane oxygenation in combination with intra-aortic balloon counterpulsation in patients with cardiovascular compromise. Cardiology 2014, 129, 137-143. [CrossRef]

113. Cheng, A.; Swartz, M.F.; Massey, H.T. Impella to unload the left ventricle during peripheral extracorporeal membrane oxygenation. ASAIO J. 2013, 59, 533-536. [CrossRef] [PubMed]

114. Patel, S.M.; Lipinski, J.; Al-Kindi, S.G.; Patel, T.; Saric, P.; Li, J.; Nadeem, F.; Ladas, T.; Alaiti, A.; Phillips, A.; et al. Simultaneous Venoarterial Extracorporeal Membrane Oxygenation and Percutaneous Left Ventricular Decompression Therapy with Impella Is Associated with Improved Outcomes in Refractory Cardiogenic Shock. ASAIO J. 2019, 65, 21-28. [CrossRef] [PubMed]

115. Pappalardo, F.; Ruggeri, L. LV distention on VA-ECMO, what to do? Qatar Med. J. 2017, 2017, 23. [CrossRef]

116. Undar, A.; Rosenberg, G.; Myers, J.L. Major factors in the controversy of pulsatile versus nonpulsatile flow during acute and chronic cardiac support. ASAIO J. 2005, 51, 173-175. [PubMed]

117. Guan, Y.; Karkhanis, T.; Wang, S.; Rider, A.; Koenig, S.C.; Slaughter, M.S.; El Banayosy, A.; Undar, A. Physiologic benefits of pulsatile perfusion during mechanical circulatory support for the treatment of acute and chronic heart failure in adults. Artif. Organs 2010, 34, 529-536. [CrossRef]

118. Kato Tomoko, S.; Chokshi, A.; Singh, P.; Khawaja, T.; Cheema, F.; Akashi, H.; Shahzad, K.; Iwata, S.; Homma, S.; Takayama, H.; et al. Effects of Continuous-Flow Versus Pulsatile-Flow Left Ventricular Assist Devices on Myocardial Unloading and Remodeling. Circ. Heart Fail. 2011, 4, 546-553. [CrossRef] [PubMed]

119. Bartoli, C.R.; Giridharan, G.A.; Litwak, K.N.; Sobieski, M.; Prabhu, S.D.; Slaughter, M.S.; Koenig, S.C. Hemodynamic Responses to Continuous versus Pulsatile Mechanical Unloading of the Failing Left Ventricle. ASAIO J. 2010, 56, 410-416. [CrossRef]

120. Alvarez, J.; Rao, V. HeartMate 3-a "Step" in the right direction. J. Thorac. Dis. 2017, 9, E457-E460. [CrossRef]

121. Mehra, M.R.; Naka, Y.; Uriel, N.; Goldstein, D.J.; Cleveland, J.C.; Colombo, P.C.; Walsh, M.N.; Milano, C.A.; Patel, C.B.; Jorde, U.P.; et al. A Fully Magnetically Levitated Circulatory Pump for Advanced Heart Failure. N. Engl. J. Med. 2016, 376, 440-450. [CrossRef]

122. Yeh, Y.C.; Lee, C.T.; Wang, C.H.; Tu, Y.K.; Lai, C.H.; Wang, Y.C.; Chao, A.; Huang, C.H.; Cheng, Y.J.; Chen, Y.S. Investigation of microcirculation in patients with venoarterial extracorporeal membrane oxygenation life support. Crit. Care 2018, 22, 200. [CrossRef]

123. Wang, S.; Izer, J.M.; Clark, J.B.; Patel, S.; Pauliks, L.; Kunselman, A.R.; Leach, D.; Cooper, T.K.; Wilson, R.P.; Undar, A. In Vivo Hemodynamic Performance Evaluation of Novel Electrocardiogram-Synchronized Pulsatile and Nonpulsatile Extracorporeal Life Support Systems in an Adult Swine Model. Artif. Organs 2015, 39, E90-E101. [CrossRef] [PubMed]

124. Sezai, A.; Shiono, M.; Nakata, K.; Hata, M.; Iida, M.; Saito, A.; Hattori, T.; Wakui, S.; Soeda, M.; Taoka, M.; et al. Effects of pulsatile CPB on interleukin-8 and endothelin-1 levels. Artif. Organs 2005, 29, 708-713. [CrossRef] [PubMed]

125. Orime, Y.; Shiono, M.; Nakata, K.; Hata, M.; Sezai, A.; Yamada, H.; Iida, M.; Kashiwazaki, S.; Nemoto, M.; Kinoshita, J.; et al. The role of pulsatility in end-organ microcirculation after cardiogenic shock. ASAIO J. 1996, 42, M724-M729. [CrossRef] [PubMed]

126. Doyle, A.J.; Hunt, B.J. Current Understanding of How Extracorporeal Membrane Oxygenators Activate Haemostasis and Other Blood Components. Front. Med. 2018, 5, 352. [CrossRef] [PubMed]

127. Camporese, G.; Bernardi, E.; Noventa, F. Update on the clinical use of the low-molecular-weight heparin, parnaparin. Vasc. Health Risk Manag. 2009, 5, 819-831. [CrossRef] [PubMed] 
128. Friedrichs, G.S.; Kilgore, K.S.; Manley, P.J.; Gralinski, M.R.; Lucchesi, B.R. Effects of heparin and N-acetyl heparin on ischemia/reperfusion-induced alterations in myocardial function in the rabbit isolated heart. Circ. Res. 1994, 75, 701-710. [CrossRef] [PubMed]

129. Park, J.L.; Kilgore, K.S.; Naylor, K.B.; Booth, E.A.; Murphy, K.L.; Lucchesi, B.R. N-Acetylheparin pretreatment reduces infarct size in the rabbit. Pharmacology 1999, 58, 120-131. [CrossRef]

130. Black, S.C.; Gralinski, M.R.; Friedrichs, G.S.; Kilgore, K.S.; Driscoll, E.M.; Lucchesi, B.R. Cardioprotective effects of heparin or $\mathrm{N}$-acetylheparin in an in vivo model of myocardial ischaemic and reperfusion injury. Cardiovasc. Res. 1995, 29, 629-636. [CrossRef]

131. Gralinski, M.R.; Driscoll, E.M.; Friedrichs, G.S.; DeNardis, M.R.; Lucchesi, B.R. Reduction of Myocardial Necrosis After Glycosaminoglycan Administration: Effects of a Single Intravenous Administration of Heparin or N-Acetylheparin 2 Hours Before Regional Ischemia and Reperfusion. J. Cardiovasc. Pharmacol. Ther. 1996, 1, 219-228.

132. Ziarek, J.J.; Veldkamp, C.T.; Zhang, F.; Murray, N.J.; Kartz, G.A.; Liang, X.; Su, J.; Baker, J.E.; Linhardt, R.J.; Volkman, B.F. Heparin oligosaccharides inhibit chemokine (CXC motif) ligand 12 (CXCL12) cardioprotection by binding orthogonal to the dimerization interface, promoting oligomerization, and competing with the chemokine (CXC motif) receptor 4 (CXCR4) N terminus. J. Biol. Chem. 2013, 288, 737-746. [CrossRef]

133. Krueger, K.; Schmutz, A.; Zieger, B.; Kalbhenn, J. Venovenous Extracorporeal Membrane Oxygenation with Prophylactic Subcutaneous Anticoagulation Only: An Observational Study in More Than 60 Patients. Artif. Organs 2017, 41, 186-192. [CrossRef] [PubMed]

134. McCully, J.D.; Levitsky, S.; Del Nido, P.J.; Cowan, D.B. Mitochondrial transplantation for therapeutic use. Clin. Transl. Med. 2016, 5, 16. [CrossRef] [PubMed]

135. Cowan, D.B.; Yao, R.; Akurathi, V.; Snay, E.R.; Thedsanamoorthy, J.K.; Zurakowski, D.; Ericsson, M.; Friehs, I.; $\mathrm{Wu}$, Y.; Levitsky, S.; et al. Intracoronary Delivery of Mitochondria to the Ischemic Heart for Cardioprotection. PLoS ONE 2016, 11, e0160889. [CrossRef] [PubMed]

136. Emani, S.M.; McCully, J.D. Mitochondrial transplantation: Applications for pediatric patients with congenital heart disease. Transl. Pediatr. 2018, 7, 169-175. [CrossRef] [PubMed]

137. Emani, S.M.; Piekarski, B.L.; Harrild, D.; Del Nido, P.J.; McCully, J.D. Autologous mitochondrial transplantation for dysfunction after ischemia-reperfusion injury. J. Thorac. Cardiovasc. Surg. 2017, 154, 286-289. [CrossRef] [PubMed]

138. Kaza, A.K.; Wamala, I.; Friehs, I.; Kuebler, J.D.; Rathod, R.H.; Berra, I.; Ericsson, M.; Yao, R.; Thedsanamoorthy, J.K.; Zurakowski, D.; et al. Myocardial rescue with autologous mitochondrial transplantation in a porcine model of ischemia/reperfusion. J. Thorac. Cardiovasc. Surg. 2017, 153, 934-943. [CrossRef] [PubMed]

139. Masuzawa, A.; Black, K.M.; Pacak, C.A.; Ericsson, M.; Barnett, R.J.; Drumm, C.; Seth, P.; Bloch, D.B.; Levitsky, S.; Cowan, D.B.; et al. Transplantation of autologously derived mitochondria protects the heart from ischemia-reperfusion injury. Am. J. Physiol. Heart Circ. Physiol. 2013, 304, H966-H982. [CrossRef] [PubMed]

140. McCully, J.D.; Cowan, D.B.; Pacak, C.A.; Toumpoulis, I.K.; Dayalan, H.; Levitsky, S. Injection of isolated mitochondria during early reperfusion for cardioprotection. Am. J. Physiol. Heart Circ. Physiol. 2009, 296, H94-H105. [CrossRef]

141. Moskowitzova, K.; Shin, B.; Liu, K.; Ramirez-Barbieri, G.; Guariento, A.; Blitzer, D.; Thedsanamoorthy, J.K.; Yao, R.; Snay, E.R.; Inkster, J.A.H.; et al. Mitochondrial transplantation prolongs cold ischemia time in murine heart transplantation. J. Heart Lung Transplant. Off. Publ. Int. Soc. Heart Transplant. 2019, 38, 92-99. [CrossRef]

142. Pacak, C.A.; Preble, J.M.; Kondo, H.; Seibel, P.; Levitsky, S.; Del Nido, P.J.; Cowan, D.B.; McCully, J.D. Actin-dependent mitochondrial internalization in cardiomyocytes: Evidence for rescue of mitochondrial function. Biol. Open 2015, 4, 622-626. [CrossRef]

143. Preble, J.M.; Pacak, C.A.; Kondo, H.; MacKay, A.A.; Cowan, D.B.; McCully, J.D. Rapid isolation and purification of mitochondria for transplantation by tissue dissociation and differential filtration. J. Vis. Exp. 2014, 91, e51682. [CrossRef] [PubMed]

144. Ramirez-Barbieri, G.; Moskowitzova, K.; Shin, B.; Blitzer, D.; Orfany, A.; Guariento, A.; Iken, K.; Friehs, I.; Zurakowski, D.; del Nido, P.J.; et al. Alloreactivity and allorecognition of syngeneic and allogeneic mitochondria. Mitochondrion 2019, 46, 103-115. [CrossRef] [PubMed] 
145. Shin, B.; Cowan, D.B.; Emani, S.M.; del Nido, P.J.; McCully, J.D. Mitochondrial Transplantation in Myocardial Ischemia and Reperfusion Injury. In Mitochondrial Dynamics in Cardiovascular Medicine; Santulli, G., Ed.; Springer International Publishing AG: Cham, Switzerland, 2017; pp. 595-619.

146. Bertero, E.; Maack, C.; O'Rourke, B. Mitochondrial transplantation in humans: "magical" cure or cause for concern? J. Clin. Investig. 2018, 128, 5191-5194. [CrossRef] [PubMed]

147. Le Blanc, K.; Davies, L.C. Mesenchymal stromal cells and the innate immune response. Immunol. Lett. 2015, 168, 140-146. [CrossRef] [PubMed]

148. Pittenger, M.F.; Mackay, A.M.; Beck, S.C.; Jaiswal, R.K.; Douglas, R.; Mosca, J.D.; Moorman, M.A.; Simonetti, D.W.; Craig, S.; Marshak, D.R. Multilineage Potential of Adult Human Mesenchymal Stem Cells. Science 1999, 284, 143. [CrossRef]

149. Paliwal, S.; Chaudhuri, R.; Agrawal, A.; Mohanty, S. Regenerative abilities of mesenchymal stem cells through mitochondrial transfer. J. Biomed. Sci. 2018, 25, 31. [CrossRef] [PubMed]

150. Singer, N.G.; Caplan, A.I. Mesenchymal Stem Cells: Mechanisms of Inflammation. Annu. Rev. Pathol. Mech. Dis. 2011, 6, 457-478. [CrossRef]

151. Liu, H.; Li, D.; Zhang, Y.; Li, M. Inflammation, mesenchymal stem cells and bone regeneration. Histochem. Cell Biol. 2018, 149, 393-404. [CrossRef]

152. Millar, J.E.; von Bahr, V.; Malfertheiner, M.V.; Ki, K.K.; Redd, M.A.; Bartnikowski, N.; Suen, J.Y.; McAuley, D.F.; Fraser, J.F. Administration of mesenchymal stem cells during ECMO results in a rapid decline in oxygenator performance. Thorax 2019, 74, 194. [CrossRef]

153. Von Bahr, V.; Millar, J.E.; Malfertheiner, M.V.; Ki, K.K.; Passmore, M.R.; Bartnikowski, N.; Redd, M.A.; Cavaye, M.; Suen, J.Y.; McAuley, D.F.; et al. Mesenchymal stem cells may ameliorate inflammation in an ex vivo model of extracorporeal membrane oxygenation. Perfusion 2019, 34, 15-21. [CrossRef]

154. Dandel, M.; Knosalla, C.; Hetzer, R. Contribution of ventricular assist devices to the recovery of failing hearts: A review and the Berlin Heart Center Experience. Eur. J. Fail. 2014, 16, 248-263. [CrossRef] [PubMed]

155. Zheng, Y.; Sampaio, L.C.; Li, K.; Silva, G.V.; Cabreira-Hansen, M.; Vela, D.; Segura, A.M.; Bovè, C.; Perin, E.C. Safety and feasibility of mapping and stem cell delivery in the presence of an implanted left ventricular assist device: A preclinical investigation in sheep. Texas Heart Inst. J. 2013, 40, 229-234.

156. Ascheim, D.D.; Gelijns, C.A.; Goldstein, A.D.; Moye, T.L.; Smedira, K.N.; Lee, O.S.; Klodell, A.C.; Szady, E.A.; Parides, G.M.; Jeffries, T.N.; et al. Mesenchymal Precursor Cells as Adjunctive Therapy in Recipients of Contemporary Left Ventricular Assist Devices. Circulation 2014, 129, 2287-2296. [CrossRef] [PubMed]

157. Yau, T.M.; Pagani, F.D.; Mancini, D.M.; Chang, H.L.; Lala, A.; Woo, Y.J.; Acker, M.A.; Selzman, C.H.; Soltesz, E.G.; Kern, J.A.; et al. Intramyocardial Injection of Mesenchymal Precursor Cells and Successful Temporary Weaning from Left Ventricular Assist Device Support in Patients with Advanced Heart Failure: A Randomized Clinical TrialIntramyocardial Injection of Mesenchymal Precursor Cells and Weaning from Left Ventricular Assist Device (LVAD) SupportIntramyocardial Injection of Mesenchymal Precursor Cells and Weaning from Left Ventricular Assist Device (LVAD) Support. JAMA 2019, 321, 1176-1186. [PubMed]

158. ANZOD. ANZOD Registry, 2017 Annual Report, Section 7: Deceased Donor Heart Donation; Australia and New Zealand Dialysis and Transplant Registry: Adelaide, Australia, 2017.

159. ANZOD. ANZOD Registry, 2017 Annual Report, Section 12: Organ Waiting Lists; Australia and New Zealand Dialysis and Transplant Registry: Adelaide, Australia, 2017.

160. The Transplantation Society of Australia and New Zealand (TSANZ). Clinical Guidelines for Organ Transplantation from Deceased Donors; Version 1.3; The Transplantation Society of Australia and New Zealand (TSANZ): Sydney, Australia, 2019.

161. Watts, R.P.; Bilska, I.; Diab, S.; Dunster, K.R.; Bulmer, A.C.; Barnett, A.G.; Fraser, J.F. Novel 24-h ovine model of brain death to study the profile of the endothelin axis during cardiopulmonary injury. Intensive Care Med. Exp. 2015, 3, 31. [CrossRef] [PubMed]

162. Watts, R.P.; Thom, O.; Fraser, J.F. Inflammatory signalling associated with brain dead organ donation: From brain injury to brain stem death and posttransplant ischaemia reperfusion injury. J. Transplant. 2013, 2013, 521369. [CrossRef]

163. Kobashigawa, J.; Zuckermann, A.; Macdonald, P.; Leprince, P.; Esmailian, F.; Luu, M.; Mancini, D.; Patel, J.; Razi, R.; Reichenspurner, H.; et al. Report from a consensus conference on primary graft dysfunction after cardiac transplantation. J. Heart Lung Transplant. 2014, 33, 327-340. [CrossRef] 
164. Wilhelm, M.J.; Pratschke, J.; Laskowski, I.A.; Paz, D.M.; Tilney, N.L. Brain death and its impact on the donor heart-lessons from animal models. J. Heart Lung Transplant. 2000, 19, 414-418. [CrossRef]

165. See Hoe, L.E.; McGiffin, D.; Fraser, J.F. Untapped potential in Australian Hospitals for organ donation after circulatory death. Med. J. Aust. 2018, 208, 276. [CrossRef]

166. Khush, K.K.; Cherikh, W.S.; Chambers, D.C.; Goldfarb, S.; Hayes, D., Jr.; Kucheryavaya, A.Y.; Levvey, B.J.; Meiser, B.; Rossano, J.W.; Stehlik, J.; et al. The International Thoracic Organ Transplant Registry of the International Society for Heart and Lung Transplantation: Thirty-fifth Adult Heart Transplantation Report-2018; Focus Theme: Multiorgan Transplantation. J. Heart Lung Transplant. 2018, 37, 1155-1168. [CrossRef]

167. Furiasse, N.; Kobashigawa, J.A. Immunosuppression and adult heart transplantation: Emerging therapies and opportunities. Expert Rev. Cardiovasc. Ther. 2017, 15, 59-69. [CrossRef] [PubMed]

168. Weis, M.; von Scheidt, W. Cardiac allograft vasculopathy: A review. Circulation 1997, 96, 2069-2077. [CrossRef] [PubMed]

169. Lindenfeld, J.; Miller, G.G.; Shakar, S.F.; Zolty, R.; Lowes, B.D.; Wolfel, E.E.; Mestroni, L.; Page, R.L.; Kobashigawa, J. Drug therapy in the heart transplant recipient: Part II: Immunosuppressive drugs. Circulation 2004, 110, 3858-3865. [CrossRef] [PubMed]

170. Shimabukuro-Vornhagen, A.; Godel, P.; Subklewe, M.; Stemmler, H.J.; Schlosser, H.A.; Schlaak, M.; Kochanek, M.; Boll, B.; von Bergwelt-Baildon, M.S. Cytokine release syndrome. J. Immunother. Cancer 2018, 6, 56. [CrossRef] [PubMed]

171. Pihusch, R.; Holler, E.; Muhlbayer, D.; Gohring, P.; Stotzer, O.; Pihusch, M.; Hiller, E.; Kolb, H.J. The impact of antithymocyte globulin on short-term toxicity after allogeneic stem cell transplantation. Bone Marrow Transpl. 2002, 30, 347-354. [CrossRef] [PubMed]

172. Wing, M.G.; Moreau, T.; Greenwood, J.; Smith, R.M.; Hale, G.; Isaacs, J.; Waldmann, H.; Lachmann, P.J.; Compston, A. Mechanism of first-dose cytokine-release syndrome by CAMPATH 1-H: Involvement of CD16 (FcgammaRIII) and CD11a/CD18 (LFA-1) on NK cells. J. Clin. Investig. 1996, 98, 2819-2826. [CrossRef]

173. Winkler, U.; Jensen, M.; Manzke, O.; Schulz, H.; Diehl, V.; Engert, A. Cytokine-release syndrome in patients with B-cell chronic lymphocytic leukemia and high lymphocyte counts after treatment with an anti-CD20 monoclonal antibody (rituximab, IDEC-C2B8). Blood 1999, 94, 2217-2224.

174. Lee, D.W.; Gardner, R.; Porter, D.L.; Louis, C.U.; Ahmed, N.; Jensen, M.; Grupp, S.A.; Mackall, C.L. Current concepts in the diagnosis and management of cytokine release syndrome. Blood 2014, 124, 188-195. [CrossRef]

175. Keogh, A. Calcineurin inhibitors in heart transplantation. J. Heart Lung Transplant. 2004, 23, S202-S206. [CrossRef]

176. Jarzembowski, T.M.; John, E.; Panaro, F.; Manzelli, A.; Cabrera, A.; Greco, A.; Varga, P.; Sankary, H.; Testa, G.; Benedetti, E. Reversal of tacrolimus-related hypertrophic obstructive cardiomyopathy 5 years after kidney transplant in a 6-year-old recipient. Pediatr. Transplant. 2005, 9, 117-121. [CrossRef]

177. Pappas, P.A.; Weppler, D.; Pinna, A.D.; Rusconi, P.; Thompson, J.F.; Jaffe, J.S.; Tzakis, A.G. Sirolimus in pediatric gastrointestinal transplantation: The use of sirolimus for pediatric transplant patients with tacrolimus-related cardiomyopathy. Pediatr. Transplant. 2000, 4, 45-49. [CrossRef]

178. Turska-Kmiec, A.; Jankowska, I.; Pawlowska, J.; Kalicinski, P.; Kawalec, W.; Tomyn, M.; Markiewicz, M.; Teisseyre, J.; Czubkowski, P.; Rekawek, J.; et al. Reversal of tacrolimus-related hypertrophic cardiomyopathy after conversion to rapamycin in a pediatric liver transplant recipient. Pediatr. Transplant. 2007, 11, 319-323. [CrossRef]

179. Cox, T.H.; Baillie, G.M.; Baliga, P. Bradycardia associated with intravenous administration of tacrolimus in a liver transplant recipient. Pharmacotherapy 1997, 17, 1328-1330.

180. Hodak, S.P.; Moubarak, J.B.; Rodriguez, I.; Gelfand, M.C.; Alijani, M.R.; Tracy, C.M. QT prolongation and near fatal cardiac arrhythmia after intravenous tacrolimus administration: A case report. Transplantation 1998, 66, 535-537. [CrossRef]

181. McLeod, J.; Wu, S.; Grazette, L.; Sarcon, A. Tacrolimus-Associated Dilated Cardiomyopathy in Adult Patient After Orthotopic Liver Transplant. J. Investig. Med. High Impact Case Rep. 2017, 5, 2324709617706087. [CrossRef]

182. Naesens, M.; Kuypers, D.R.; Sarwal, M. Calcineurin inhibitor nephrotoxicity. Clin. J. Am. Soc. Nephrol. 2009, 4, 481-508. [CrossRef] 
183. Lyson, T.; Ermel, L.D.; Belshaw, P.J.; Alberg, D.G.; Schreiber, S.L.; Victor, R.G. Cyclosporine- and FK506-induced sympathetic activation correlates with calcineurin-mediated inhibition of T-cell signaling. Circ. Res. 1993, 73, 596-602. [CrossRef]

184. Pham, S.M.; Kormos, R.L.; Hattler, B.G.; Kawai, A.; Tsamandas, A.C.; Demetris, A.J.; Murali, S.; Fricker, F.J.; Chang, H.C.; Jain, A.B.; et al. A prospective trial of tacrolimus (FK 506) in clinical heart transplantation: Intermediate-term results. J. Thorac. Cardiovasc. Surg. 1996, 111, 764-772. [CrossRef]

185. Meiser, B.M.; Billingham, M.E.; Morris, R.E. Effects of cyclosporin, FK506, and rapamycin on graft-vessel disease. Lancet 1991, 338, 1297-1298. [CrossRef]

186. Arai, S.; Teramoto, S.; Senoo, Y. The impact of FK506 on graft coronary disease of rat cardiac allograft-A comparison with cyclosporine. J. Heart Lung Transplant. 1992, 11, 757-762.

187. Chi, J.; Zhu, Y.; Fu, Y.; Liu, Y.; Zhang, X.; Han, L.; Yin, X.; Zhao, D. Cyclosporin A induces apoptosis in $\mathrm{H} 9 \mathrm{c} 2$ cardiomyoblast cells through calcium-sensing receptor-mediated activation of the ERK MAPK and p38 MAPK pathways. Mol. Cell. Biochem. 2012, 367, 227-236. [CrossRef]

188. Buetler, T.M.; Cottet-Maire, F.; Krauskopf, A.; Ruegg, U.T. Does cyclosporin A generate free radicals? Trends Pharmacol. Sci. 2000, 21, 288-290. [CrossRef]

189. Selcoki, Y.; Uz, E.; Bayrak, R.; Sahin, S.; Kaya, A.; Uz, B.; Karanfil, A.; Ozkara, A.; Akcay, A. The protective effect of erdosteine against cyclosporine A-induced cardiotoxicity in rats. Toxicology 2007, 239, 53-59. [CrossRef]

190. Tang, J.; Wang, G.; Liu, Y.; Fu, Y.; Chi, J.; Zhu, Y.; Zhao, Y.; Yin, X. Cyclosporin A induces cardiomyocyte injury through calcium-sensing receptor-mediated calcium overload. Pharmazie 2011, 66, 52-57.

191. Serkova, N.J.; Christians, U.; Benet, L.Z. Biochemical mechanisms of cyclosporine neurotoxicity. Mol. Interv. 2004, 4, 97-107. [CrossRef]

192. Omar, A.G.; El-Mas, M.M. Time-domain evaluation of cyclosporine interaction with hemodynamic variability in rats. Cardiovasc. Drugs Ther. 2004, 18, 461-468. [CrossRef]

193. Moien-Afshari, F.; McManus, B.M.; Laher, I. Immunosuppression and transplant vascular disease: Benefits and adverse effects. Pharmacol. Ther. 2003, 100, 141-156. [CrossRef]

194. Reichart, B.; Meiser, B.; Vigano, M.; Rinaldi, M.; Martinelli, L.; Yacoub, M.; Banner, N.R.; Gandjbakhch, I.; Dorent, R.; Hetzer, R.; et al. European Multicenter Tacrolimus (FK506) Heart Pilot Study: One-year results-European Tacrolimus Multicenter Heart Study Group. J. Heart Lung Transplant. 1998, 17, 775-781.

195. Meiser, B.M.; Uberfuhr, P.; Fuchs, A.; Schmidt, D.; Pfeiffer, M.; Paulus, D.; Schulze, C.; Wildhirt, S.; Scheidt, W.V.; Angermann, C.; et al. Single-center randomized trial comparing tacrolimus (FK506) and cyclosporine in the prevention of acute myocardial rejection. J. Heart Lung Transplant. 1998, 17, 782-788.

196. Teebken, O.E.; Struber, M.; Harringer, W.; Pichlmaier, M.A.; Haverich, A. Primary immunosuppression with tacrolimus and mycophenolate mofetil versus cyclosporine and azathioprine in heart transplant recipients. Transplant. Proc. 2002, 34, 1265-1268. [CrossRef]

197. Rinaldi, M.; Pellegrini, C.; Martinelli, L.; Goggi, C.; Gavazzi, A.; Campana, C.; Arbustini, E.; Grossi, P.; Regazzi, M.; Ippoliti, G.; et al. FK506 effectiveness in reducing acute rejection after heart transplantation: A prospective randomized study. J. Heart Lung Transplant. 1997, 16, 1001-1010.

198. Czerny, M.; Sahin, V.; Fasching, P.; Zuckermann, A.; Zimpfer, D.; Kilo, J.; Wolner, E.; Grimm, M. The impact of diabetes mellitus at the time of heart transplantation on long-term survival. Diabetologia 2002, 45, 1498-1508.

199. Taylor, D.O.; Barr, M.L.; Radovancevic, B.; Renlund, D.G.; Mentzer, R.M., Jr.; Smart, F.W.; Tolman, D.E.; Frazier, O.H.; Young, J.B.; VanVeldhuisen, P. A randomized, multicenter comparison of tacrolimus and cyclosporine immunosuppressive regimens in cardiac transplantation: Decreased hyperlipidemia and hypertension with tacrolimus. J. Heart Lung Transplant. 1999, 18, 336-345. [CrossRef]

200. Kristeller, J.L.; Jankowski, A.; Reinaker, T. Role of corticosteroids during cardiopulmonary bypass. Hosp. Pharm. 2014, 49, 232-236. [CrossRef]

201. Williams, C.M.; Coleman, J.W. Induced expression of mRNA for IL-5, IL-6, TNF-alpha, MIP-2 and IFN-gamma in immunologically activated rat peritoneal mast cells: Inhibition by dexamethasone and cyclosporin A. Immunology 1995, 86, 244-249.

202. Pfeffer, M.A.; Braunwald, E. Ventricular remodeling after myocardial infarction. Experimental observations and clinical implications. Circulation 1990, 81, 1161-1172. [CrossRef]

203. Silverman, H.S.; Pfeifer, M.P. Relation between use of anti-inflammatory agents and left ventricular free wall rupture during acute myocardial infarction. Am. J. Cardiol. 1987, 59, 363-364. [CrossRef] 
204. Hammerman, H.; Schoen, F.J.; Braunwald, E.; Kloner, R.A. Drug-induced expansion of infarct: Morphologic and functional correlations. Circulation 1984, 69, 611-617. [CrossRef]

205. Mannisi, J.A.; Weisman, H.F.; Bush, D.E.; Dudeck, P.; Healy, B. Steroid administration after myocardial infarction promotes early infarct expansion. A study in the rat. J. Clin. Investig. 1987, 79, 1431-1439. [CrossRef]

206. Garcia, R.A.; Go, K.V.; Villarreal, F.J. Effects of timed administration of doxycycline or methylprednisolone on post-myocardial infarction inflammation and left ventricular remodeling in the rat heart. Mol. Cell. Biochem. 2007, 300, 159-169. [CrossRef]

207. Costanzo, M.R.; Dipchand, A.; Starling, R.; Anderson, A.; Chan, M.; Desai, S.; Fedson, S.; Fisher, P.; Gonzales-Stawinski, G.; Martinelli, L.; et al. The International Society of Heart and Lung Transplantation Guidelines for the care of heart transplant recipients. J. Heart Lung Transplant. 2010, 29, 914-956. [CrossRef] [PubMed]

208. Teuteberg, J.J.; Shullo, M.; Zomak, R.; McNamara, D.; McCurry, K.; Kormos, R.L. Aggressive steroid weaning after cardiac transplantation is possible without the additional risk of significant rejection. Clin. Transplant. 2008, 22, 730-737. [CrossRef] [PubMed]

209. Taylor, D.O.; Bristow, M.R.; O'Connell, J.B.; Price, G.D.; Hammond, E.H.; Doty, D.B.; Karwande, S.V.; Gay, W.A., Jr.; Jones, K.W.; Lappe, D.; et al. Improved long-term survival after heart transplantation predicted by successful early withdrawal from maintenance corticosteroid therapy. J. Heart Lung Transplant. 1996, 15, 1039-1046. [PubMed]

210. Ballantyne, C.M.; Radovancevic, B.; Farmer, J.A.; Frazier, O.H.; Chandler, L.; Payton-Ross, C.; Cocanougher, B.; Jones, P.H.; Young, J.B.; Gotto, A.M., Jr. Hyperlipidemia after heart transplantation: Report of a 6-year experience, with treatment recommendations. J. Am. Coll. Cardiol. 1992, 19, 1315-1321. [CrossRef]

211. Bamgbola, O. Metabolic consequences of modern immunosuppressive agents in solid organ transplantation. Ther. Adv. Endocrinol. Metab. 2016, 7, 110-127. [CrossRef] [PubMed]

212. Nussinovitch, U.; de Carvalho, J.F.; Pereira, R.M.; Shoenfeld, Y. Glucocorticoids and the cardiovascular system: State of the art. Curr. Pharm. Des. 2010, 16, 3574-3585. [CrossRef] [PubMed]

213. Sartori, T.M.; Maurizio, P.G.; Sara, P.; Ugolino, L.; Annalisa, A.; Panagiotis, T.; Massimo, F.; Antonio, G. Relation between long-term steroid treatment after heart transplantation, hypofibrinolysis and myocardial microthrombi generation. J. Heart Lung Transplant. 1999, 18, 693-700. [CrossRef]

214. Sack, M.N.; Murphy, E. The role of comorbidities in cardioprotection. J. Cardiovasc. Pharmacol. Ther. 2011, 16, 267-272. [CrossRef]

215. Ferdinandy, P.; Hausenloy, D.J.; Heusch, G.; Baxter, G.F.; Schulz, R. Interaction of risk factors, comorbidities, and comedications with ischemia/reperfusion injury and cardioprotection by preconditioning, postconditioning, and remote conditioning. Pharmacol. Rev. 2014, 66, 1142-1174. [CrossRef]

216. Habertheuer, A.; Kocher, A.; Laufer, G.; Andreas, M.; Szeto, W.Y.; Petzelbauer, P.; Ehrlich, M.; Wiedemann, D. Cardioprotection: A review of current practice in global ischemia and future translational perspective. BioMed Res. Int. 2014, 2014, 325725. [CrossRef]

217. Yamamoto, H.; Yamamoto, F. Myocardial protection in cardiac surgery: A historical review from the beginning to the current topics. Gen. Thorac. Cardiovasc. Surg. 2013, 61, 485-496. [CrossRef]

218. Steen, S.; Paskevicius, A.; Liao, Q.; Sjoberg, T. Safe orthotopic transplantation of hearts harvested 24 hours after brain death and preserved for 24 hours. Scand. Cardiovasc. J. 2016, 50, 193-200. [CrossRef]

219. Nilsson, J.; Jernryd, V.; Qin, G.; Paskevicius, A.; Sjoberg, T.; Hoglund, P.; Steen, S. Non Ischemic Heart Preservation-Results from the Safety Study. J. Heart Lung Transplant. 2019, 38, S26. [CrossRef]

220. Michel, S.G.; LaMuraglia Ii, G.M.; Madariaga, M.L.; Anderson, L.M. Innovative cold storage of donor organs using the Paragonix Sherpa Pak devices. Heart Lung Vessel 2015, 7, 246-255.

221. Naito, N.; Funamoto, M.; Pierson, R.; Villavicencio, M.; Riley, W.; Lewis, G.; D'Alessandro, D. The First Clinical Use of a Novel Cold Storage System of Donor Hearts. J. Heart Lung Transplant. 2019, 38, S44. [CrossRef]

222. Ardehali, A.; Esmailian, F.; Deng, M.; Soltesz, E.; Hsich, E.; Naka, Y.; Mancini, D.; Camacho, M.; Zucker, M.; Leprince, P.; et al. Ex-vivo perfusion of donor hearts for human heart transplantation (PROCEED II): A prospective, open-label, multicentre, randomised non-inferiority trial. Lancet 2015, 385, 2577-2584. [CrossRef]

223. Wood, K.J.; Bushell, A.; Hester, J. Regulatory immune cells in transplantation. Nat. Rev. Immunol. 2012, 12, 417-430. [CrossRef] 
224. Hester, J.; Schiopu, A.; Nadig, S.N.; Wood, K.J. Low-dose rapamycin treatment increases the ability of human regulatory T cells to inhibit transplant arteriosclerosis in vivo. Am. J. Transplant. 2012, 12, 2008-2016. [CrossRef]

225. Kingsley, C.I.; Karim, M.; Bushell, A.R.; Wood, K.J. CD25+CD4+ regulatory T cells prevent graft rejection: CTLA-4- and IL-10-dependent immunoregulation of alloresponses. J. Immunol. 2002, 168, 1080-1086. [CrossRef]

226. Xia, N.; Jiao, J.; Tang, T.T.; Lv, B.J.; Lu, Y.Z.; Wang, K.J.; Zhu, Z.F.; Mao, X.B.; Nie, S.F.; Wang, Q.; et al. Activated regulatory T-cells attenuate myocardial ischaemia/reperfusion injury through a CD39-dependent mechanism. Clin. Sci. 2015, 128, 679-693. [CrossRef]

227. Hoerbelt, R.; Benjamin, C.L.; Shoji, T.; Houser, S.L.; Muniappan, A.; Hasse, R.S.; Ledgerwood, L.G.; Allan, J.S.; Sachs, D.H.; Madsen, J.C. The effects of tolerance on allograft damage caused by the innate immune system. Transplantation 2008, 85, 314-322. [CrossRef]

228. Lila, N.; Amrein, C.; Guillemain, R.; Chevalier, P.; Latremouille, C.; Fabiani, J.N.; Dausset, J.; Carosella, E.D.; Carpentier, A. Human leukocyte antigen-G expression after heart transplantation is associated with a reduced incidence of rejection. Circulation 2002, 105, 1949-1954. [CrossRef]

229. Lila, N.; Amrein, C.; Guillemain, R.; Chevalier, P.; Fabiani, J.N.; Carpentier, A. Soluble human leukocyte antigen-G: A new strategy for monitoring acute and chronic rejections after heart transplantation. J. Heart Lung Transplant. 2007, 26, 421-422. [CrossRef]

230. Sheshgiri, R.; Gustafsson, F.; Sheedy, J.; Rao, V.; Ross, H.J.; Delgado, D.H. Everolimus but not mycophenolate mofetil therapy is associated with soluble HLA-G expression in heart transplant patients. J. Heart Lung Transplant. 2009, 28, 1193-1197. [CrossRef]

231. Ferjani, H.; Timoumi, R.; Amara, I.; Abid, S.; Achour, A.; Bacha, H.; Boussema-Ayed, I. Beneficial effects of mycophenolate mofetil on cardiotoxicity induced by tacrolimus in wistar rats. Exp. Biol. Med. (Maywood) 2017, 242, 448-455. [CrossRef]

232. Al-Harbi, N.O.; Imam, F.; Nadeem, A.; Al-Harbi, M.M.; Iqbal, M.; Rahman, S.; Al-Hosaini, K.A.; Bahashwan, S. Protection against tacrolimus-induced cardiotoxicity in rats by olmesartan and aliskiren. Toxicol. Mech. Methods 2014, 24, 697-702. [CrossRef]

233. Behbod, F.; Erwin-Cohen, R.A.; Wang, M.E.; Trawick, B.W.; Qu, X.; Verani, R.; Kahan, B.D.; Stepkowski, S.M.; Kirken, R.A. Concomitant inhibition of Janus kinase 3 and calcineurin-dependent signaling pathways synergistically prolongs the survival of rat heart allografts. J. Immunol. 2001, 166, 3724-3732. [CrossRef]

234. Piot, C.; Croisille, P.; Staat, P.; Thibault, H.; Rioufol, G.; Mewton, N.; Elbelghiti, R.; Cung, T.T.; Bonnefoy, E.; Angoulvant, D.; et al. Effect of cyclosporine on reperfusion injury in acute myocardial infarction. N. Engl. J. Med. 2008, 359, 473-481. [CrossRef]

235. Cung, T.T.; Morel, O.; Cayla, G.; Rioufol, G.; Garcia-Dorado, D.; Angoulvant, D.; Bonnefoy-Cudraz, E.; Guerin, P.; Elbaz, M.; Delarche, N.; et al. Cyclosporine before PCI in Patients with Acute Myocardial Infarction. N. Engl. J. Med. 2015, 373, 1021-1031. [CrossRef]

236. Mewton, N.; Croisille, P.; Gahide, G.; Rioufol, G.; Bonnefoy, E.; Sanchez, I.; Cung, T.T.; Sportouch, C.; Angoulvant, D.; Finet, G.; et al. Effect of cyclosporine on left ventricular remodeling after reperfused myocardial infarction. J. Am. Coll. Cardiol. 2010, 55, 1200-1205. [CrossRef]

237. Ikeda, G.; Matoba, T.; Nakano, Y.; Nagaoka, K.; Ishikita, A.; Nakano, K.; Funamoto, D.; Sunagawa, K.; Egashira, K. Nanoparticle-Mediated Targeting of Cyclosporine a Enhances Cardioprotection Against Ischemia-Reperfusion Injury Through Inhibition of Mitochondrial Permeability Transition Pore Opening. Sci. Rep. 2016, 6, 20467. [CrossRef]

238. Xue, Q.; Patterson, A.J.; Xiao, D.; Zhang, L. Glucocorticoid modulates angiotensin II receptor expression patterns and protects the heart from ischemia and reperfusion injury. PLoS ONE 2014, 9, e106827. [CrossRef]

239. Libby, P.; Maroko, P.R.; Bloor, C.M.; Sobel, B.E.; Braunwald, E. Reduction of experimental myocardial infarct size by corticosteroid administration. J. Clin. Investig. 1973, 52, 599-607. [CrossRef]

240. Hafezi-Moghadam, A.; Simoncini, T.; Yang, Z.; Limbourg, F.P.; Plumier, J.C.; Rebsamen, M.C.; Hsieh, C.M.; Chui, D.S.; Thomas, K.L.; Prorock, A.J.; et al. Acute cardiovascular protective effects of corticosteroids are mediated by non-transcriptional activation of endothelial nitric oxide synthase. Nat. Med. 2002, 8, 473-479. [CrossRef]

241. Tuuminen, R.; Syrjala, S.; Krebs, R.; Arnaudova, R.; Rouvinen, E.; Nykanen, A.I.; Lemstrom, K.B. Combined donor simvastatin and methylprednisolone treatment prevents ischemia-reperfusion injury in rat cardiac allografts through vasculoprotection and immunomodulation. Transplantation 2013, 95, 1084-1091. [CrossRef] 
242. Enc, Y.; Karaca, P.; Ayoglu, U.; Camur, G.; Kurc, E.; Cicek, S. The acute cardioprotective effect of glucocorticoid in myocardial ischemia-reperfusion injury occurring during cardiopulmonary bypass. Heart Vessel. 2006, 21, 152-156. [CrossRef]

243. Schmidbauer, G.; Homeyer, A.; Bohle, R.M.; Grimm, H.; Binder, J.; Kupiec-Weglinski, J.W. Donor pretreatment with methylprednisolone synergistically prolongs survival of cardiac allografts in sensitized rat recipients conditioned with rapamycin. Transplant. Proc. 1997, 29, 607-608. [CrossRef]

244. Auphan, N.; DiDonato, J.A.; Rosette, C.; Helmberg, A.; Karin, M. Immunosuppression by glucocorticoids: Inhibition of NF-kappa B activity through induction of I kappa B synthesis. Science 1995, 270, $286-290$. [CrossRef]

245. Thiemermann, C. Corticosteroids and cardioprotection. Nat. Med. 2002, 8, 453-455. [CrossRef]

246. Tokudome, S.; Sano, M.; Shinmura, K.; Matsuhashi, T.; Morizane, S.; Moriyama, H.; Tamaki, K.; Hayashida, K.; Nakanishi, H.; Yoshikawa, N.; et al. Glucocorticoid protects rodent hearts from ischemia/reperfusion injury by activating lipocalin-type prostaglandin D synthase-derived PGD2 biosynthesis. J. Clin. Investig. 2009, 119, 1477-1488. [CrossRef]

247. Eguchi, Y.; Eguchi, N.; Oda, H.; Seiki, K.; Kijima, Y.; Matsu-ura, Y.; Urade, Y.; Hayaishi, O. Expression of lipocalin-type prostaglandin D synthase (beta-trace) in human heart and its accumulation in the coronary circulation of angina patients. Proc. Natl. Acad. Sci. USA 1997, 94, 14689-14694. [CrossRef]

248. Katsumata, Y.; Shinmura, K.; Sugiura, Y.; Tohyama, S.; Matsuhashi, T.; Ito, H.; Yan, X.; Ito, K.; Yuasa, S.; Ieda, M.; et al. Endogenous prostaglandin D2 and its metabolites protect the heart against ischemia-reperfusion injury by activating Nrf2. Hypertension 2014, 63, 80-87. [CrossRef]

249. Ma, Q. Role of nrf2 in oxidative stress and toxicity. Annu. Rev. Pharmacol. Toxicol. 2013, 53, 401-426. [CrossRef]

250. Belhaj, A.; Dewachter, L.; Rorive, S.; Remmelink, M.; Weynand, B.; Melot, C.; Galanti, L.; Hupkens, E.; Sprockeels, T.; Dewachter, C.; et al. Roles of inflammation and apoptosis in experimental brain death-induced right ventricular failure. J. Heart Lung Transplant. 2016, 35, 1505-1518. [CrossRef]

251. McLean, K.M.; Duffy, J.Y.; Pandalai, P.K.; Lyons, J.M.; Bulcao, C.F.; Wagner, C.J.; Akhter, S.A.; Pearl, J.M. Glucocorticoids alter the balance between pro- and anti-inflammatory mediators in the myocardium in a porcine model of brain death. J. Heart Lung Transplant. 2007, 26, 78-84. [CrossRef]

252. Wan, S.; DeSmet, J.M.; Antoine, M.; Goldman, M.; Vincent, J.L.; LeClerc, J.L. Steroid administration in heart and heart-lung transplantation: Is the timing adequate? Ann. Thorac. Surg. 1996, 61, 674-678. [CrossRef]

253. Sandha, J.K.; White, C.W.; Muller, A.; Avery, E.; Thliveris, J.; Dixon, I.M.C.; Arora, R.C.; Tian, G.; Hryshko, L.V.; Nagendran, J.; et al. Steroids Limit Myocardial Edema During Ex Vivo Perfusion of Hearts Donated After Circulatory Death. Ann. Thorac. Surg. 2018, 105, 1763-1770. [CrossRef]

254. Pesonen, E.; Keski-Nisula, J.; Passov, A.; Vahatalo, R.; Puntila, J.; Andersson, S.; Suominen, P.K. Heart-Type Fatty Acid Binding Protein and High-Dose Methylprednisolone in Pediatric Cardiac Surgery. J. Cardiothorac. Vasc. Anesth. 2017, 31, 1952-1956. [CrossRef]

255. Dhar, R.; Cotton, C.; Coleman, J.; Brockmeier, D.; Kappel, D.; Marklin, G.; Wright, R. Comparison of highand low-dose corticosteroid regimens for organ donor management. J. Crit. Care 2013, 28, 111-e1. [CrossRef]

256. Segel, L.D.; Follette, D.M.; Castellanos, L.M.; Hayes, R.; Baker, J.M.; Smolens, I.V. Steroid pretreatment improves graft recovery in a sheep orthotopic heart transplantation model. J. Heart Lung Transplant. 1997, 16, 371-380.

257. Huber, B.C.; Ransohoff, J.D.; Ransohoff, K.J.; Riegler, J.; Ebert, A.; Kodo, K.; Gong, Y.; Sanchez-Freire, V.; Dey, D.; Kooreman, N.G.; et al. Costimulation-adhesion blockade is superior to cyclosporine A and prednisone immunosuppressive therapy for preventing rejection of differentiated human embryonic stem cells following transplantation. Stem Cells 2013, 31, 2354-2363. [CrossRef]

258. Foldes, G.; Mioulane, M.; Kodagoda, T.; Lendvai, Z.; Iqbal, A.; Ali, N.N.; Schneider, M.D.; Harding, S.E. Immunosuppressive agents modulate function, growth, and survival of cardiomyocytes and endothelial cells derived from human embryonic stem cells. Stem Cells Dev. 2014, 23, 467-476. [CrossRef]

259. Crockford, D.; Turjman, N.; Allan, C.; Angel, J. Thymosin beta4: Structure, function, and biological properties supporting current and future clinical applications. Ann. N. Y. Acad. Sci. 2010, 1194, 179-189. [CrossRef]

260. Hinkel, R.; El-Aouni, C.; Olson, T.; Horstkotte, J.; Mayer, S.; Muller, S.; Willhauck, M.; Spitzweg, C.; Gildehaus, F.J.; Munzing, W.; et al. Thymosin beta4 is an essential paracrine factor of embryonic endothelial progenitor cell-mediated cardioprotection. Circulation 2008, 117, 2232-2240. [CrossRef] 
261. Postrach, J.; Schmidt, M.; Thormann, M.; Thein, E.; Burdorf, L.; Reichart, B.; Sotlar, K.; Walz, C.; Faber, C.; Bauer, A.; et al. Adeno-associated viral vector 2.9 thymosin ss 4 application attenuates rejection after heart transplantation: Results of a preclinical study in the pig. Transplantation 2014, 98, 835-843. [CrossRef]

262. Schuleri, K.H.; Amado, L.C.; Boyle, A.J.; Centola, M.; Saliaris, A.P.; Gutman, M.R.; Hatzistergos, K.E.; Oskouei, B.N.; Zimmet, J.M.; Young, R.G.; et al. Early improvement in cardiac tissue perfusion due to mesenchymal stem cells. Am. J. Physiol. Heart Circ. Physiol. 2008, 294, H2002-H2011. [CrossRef]

263. Hatzistergos, K.E.; Quevedo, H.; Oskouei, B.N.; Hu, Q.; Feigenbaum, G.S.; Margitich, I.S.; Mazhari, R.; Boyle, A.J.; Zambrano, J.P.; Rodriguez, J.E.; et al. Bone marrow mesenchymal stem cells stimulate cardiac stem cell proliferation and differentiation. Circ. Res. 2010, 107, 913-922. [CrossRef]

264. Karantalis, V.; Hare, J.M. Use of mesenchymal stem cells for therapy of cardiac disease. Circ. Res. 2015, 116, 1413-1430. [CrossRef]

265. Sanina, C.; Hare, J.M. Mesenchymal Stem Cells as a Biological Drug for Heart Disease: Where Are We with Cardiac Cell-Based Therapy? Circ. Res. 2015, 117, 229-233. [CrossRef]

266. Popp, F.C.; Eggenhofer, E.; Renner, P.; Slowik, P.; Lang, S.A.; Kaspar, H.; Geissler, E.K.; Piso, P.; Schlitt, H.J.; Dahlke, M.H. Mesenchymal stem cells can induce long-term acceptance of solid organ allografts in synergy with low-dose mycophenolate. Transpl. Immunol. 2008, 20, 55-60. [CrossRef]

267. Inoue, S.; Popp, F.C.; Koehl, G.E.; Piso, P.; Schlitt, H.J.; Geissler, E.K.; Dahlke, M.H. Immunomodulatory effects of mesenchymal stem cells in a rat organ transplant model. Transplantation 2006, 81, 1589-1595. [CrossRef] [PubMed]

268. Hall, B.M.; Jelbart, M.E.; Dorsch, S.E. Suppressor T cells in rats with prolonged cardiac allograft survival after treatment with cyclosporine. Transplantation 1984, 37, 595-600. [CrossRef] [PubMed]

269. Hall, B.M.; Pearce, N.W.; Gurley, K.E.; Dorsch, S.E. Specific unresponsiveness in rats with prolonged cardiac allograft survival after treatment with cyclosporine. III. Further characterization of the CD4+ suppressor cell and its mechanisms of action. J. Exp. Med. 1990, 171, 141-157. [CrossRef] [PubMed]

270. Bushell, A.; Wood, K. GITR ligation blocks allograft protection by induced CD25+CD4+ regulatory T cells without enhancing effector T-cell function. Am. J. Transplant. 2007, 7, 759-768. [CrossRef] [PubMed]

271. Tsang, J.Y.; Tanriver, Y.; Jiang, S.; Xue, S.A.; Ratnasothy, K.; Chen, D.; Stauss, H.J.; Bucy, R.P.; Lombardi, G.; Lechler, R. Conferring indirect allospecificity on CD4+CD25+ Tregs by TCR gene transfer favors transplantation tolerance in mice. J. Clin. Investig. 2008, 118, 3619-3628. [CrossRef]

272. McMurchy, A.N.; Bushell, A.; Levings, M.K.; Wood, K.J. Moving to tolerance: Clinical application of T regulatory cells. Semin. Immunol. 2011, 23, 304-313. [CrossRef] [PubMed]

273. Sanchez-Fueyo, A.; Sandner, S.; Habicht, A.; Mariat, C.; Kenny, J.; Degauque, N.; Zheng, X.X.; Strom, T.B.; Turka, L.A.; Sayegh, M.H. Specificity of CD4+CD25+ regulatory T cell function in alloimmunity. J. Immunol. 2006, 176, 329-334. [CrossRef] [PubMed]

274. Kang, S.M.; Tang, Q.; Bluestone, J.A. CD4+CD25+ regulatory T cells in transplantation: Progress, challenges and prospects. Am. J. Transplant. 2007, 7, 1457-1463. [CrossRef]

275. Raimondi, G.; Sumpter, T.L.; Matta, B.M.; Pillai, M.; Corbitt, N.; Vodovotz, Y.; Wang, Z.; Thomson, A.W. Mammalian target of rapamycin inhibition and alloantigen-specific regulatory $\mathrm{T}$ cells synergize to promote long-term graft survival in immunocompetent recipients. J. Immunol. 2010, 184, 624-636. [CrossRef]

276. Pilat, N.; Farkas, A.M.; Mahr, B.; Schwarz, C.; Unger, L.; Hock, K.; Oberhuber, R.; Aumayr, K.; Wrba, F.; Wekerle, T. T-regulatory cell treatment prevents chronic rejection of heart allografts in a murine mixed chimerism model. J. Heart Lung Transplant. 2014, 33, 429-437. [CrossRef]

277. Battaglia, M.; Stabilini, A.; Migliavacca, B.; Horejs-Hoeck, J.; Kaupper, T.; Roncarolo, M.G. Rapamycin promotes expansion of functional CD4+CD25+FOXP3+ regulatory T cells of both healthy subjects and type 1 diabetic patients. J. Immunol. 2006, 177, 8338-8347. [CrossRef] [PubMed]

278. Scotta, C.; Esposito, M.; Fazekasova, H.; Fanelli, G.; Edozie, F.C.; Ali, N.; Xiao, F.; Peakman, M.; Afzali, B.; Sagoo, P.; et al. Differential effects of rapamycin and retinoic acid on expansion, stability and suppressive qualities of human CD4(+)CD25(+)FOXP3(+) T regulatory cell subpopulations. Haematologica 2013, 98, 1291-1299. [CrossRef] [PubMed]

279. Segundo, D.S.; Ruiz, J.C.; Izquierdo, M.; Fernandez-Fresnedo, G.; Gomez-Alamillo, C.; Merino, R.; Benito, M.J.; Cacho, E.; Rodrigo, E.; Palomar, R.; et al. Calcineurin inhibitors, but not rapamycin, reduce percentages of CD4+CD25+FOXP3+ regulatory T cells in renal transplant recipients. Transplantation 2006, 82, 550-557. [CrossRef] [PubMed] 
280. Pearl, J.P.; Parris, J.; Hale, D.A.; Hoffmann, S.C.; Bernstein, W.B.; McCoy, K.L.; Swanson, S.J.; Mannon, R.B.; Roederer, M.; Kirk, A.D. Immunocompetent T-cells with a memory-like phenotype are the dominant cell type following antibody-mediated T-cell depletion. Am. J. Transplant. 2005, 5, 465-474. [CrossRef] [PubMed]

281. Wever-Pinzon, O.; Edwards, L.B.; Taylor, D.O.; Kfoury, A.G.; Drakos, S.G.; Selzman, C.H.; Fang, J.C.; Lund, L.H.; Stehlik, J. Association of recipient age and causes of heart transplant mortality: Implications for personalization of post-transplant management-An analysis of the International Society for Heart and Lung Transplantation Registry. J. Heart Lung Transplant. 2017, 36, 407-417. [CrossRef] [PubMed]

282. Bangash, M.N.; Kong, M.L.; Pearse, R.M. Use of inotropes and vasopressor agents in critically ill patients. Br. J. Pharmacol. 2012, 165, 2015-2033. [CrossRef] [PubMed]

283. Pappalardo, F.; Pieri, M.; Arnaez Corada, B.; Ajello, S.; Melisurgo, G.; De Bonis, M.; Zangrillo, A. Timing and Strategy for Weaning from Venoarterial ECMO are Complex Issues. J. Cardiothorac. Vasc. Anesth. 2015, 29, 906-911. [CrossRef] [PubMed]

284. Maack, C.; Eschenhagen, T.; Hamdani, N.; Heinzel, F.R.; Lyon, A.R.; Manstein, D.J.; Metzger, J.; Papp, Z.; Tocchetti, C.G.; Yilmaz, M.B.; et al. Treatments targeting inotropy. Eur. Heart J. 2018, 39. [CrossRef] [PubMed]

285. Fellahi, J.L.; Fischer, M.O.; Daccache, G.; Gerard, J.L.; Hanouz, J.L. Positive inotropic agents in myocardial ischemia-reperfusion injury: A benefit/risk analysis. Anesthesiology 2013, 118, 1460-1465. [CrossRef]

286. Da Luz, V.F.; Otsuki, D.A.; Gonzalez, M.M.; Negri, E.M.; Caldini, E.G.; Damaceno-Rodrigues, N.R.; Malbouisson, L.M.; Viana, B.G.; Vane, M.F.; Carmona, M.J. Myocardial protection induced by fentanyl in pigs exposed to high-dose adrenaline. Clin. Exp. Pharmacol. Physiol. 2015, 42, 1098-1107. [CrossRef]

287. Najafi, A.; Sequeira, V.; Kuster, D.W.; van der Velden, J. beta-adrenergic receptor signalling and its functional consequences in the diseased heart. Eur. J. Clin. Investig. 2016, 46, 362-374. [CrossRef] [PubMed]

288. Rajadurai, M.; Stanely Mainzen Prince, P. Preventive effect of naringin on cardiac markers, electrocardiographic patterns and lysosomal hydrolases in normal and isoproterenol-induced myocardial infarction in Wistar rats. Toxicology 2007, 230, 178-188. [CrossRef]

289. Rajadurai, M.; Stanely Mainzen Prince, P. Preventive effect of naringin on lipid peroxides and antioxidants in isoproterenol-induced cardiotoxicity in Wistar rats: Biochemical and histopathological evidences. Toxicology 2006, 228, 259-268. [CrossRef] [PubMed]

290. Rajadurai, M.; Stanely Mainzen Prince, P. Preventive effect of naringin on lipids, lipoproteins and lipid metabolic enzymes in isoproterenol-induced myocardial infarction in Wistar rats. J. Biochem. Mol. Toxicol. 2006, 20, 191-197. [CrossRef] [PubMed]

291. Nichtova, Z.; Novotova, M.; Kralova, E.; Stankovicova, T. Morphological and functional characteristics of models of experimental myocardial injury induced by isoproterenol. Gen. Physiol. Biophys. 2012, 31, 141-151. [CrossRef] [PubMed]

292. Berman, M.; Ali, A.; Ashley, E.; Freed, D.; Clarke, K.; Tsui, S.; Parameshwar, J.; Large, S. Is stress cardiomyopathy the underlying cause of ventricular dysfunction associated with brain death? J. Heart Lung Transplant. 2010, 29, 957-965. [CrossRef] [PubMed]

293. Couch, L.S.; Harding, S.E. Takotsubo Syndrome: Stress or NO Stress? JACC Basic Transl. Sci. 2018, 3, $227-229$. [CrossRef] [PubMed]

294. Ansari, U.; El-Battrawy, I.; Fastner, C.; Behnes, M.; Sattler, K.; Huseynov, A.; Baumann, S.; Tulumen, E.; Borggrefe, M.; Akin, I. Clinical outcomes associated with catecholamine use in patients diagnosed with Takotsubo cardiomyopathy. BMC Cardiovasc. Disord. 2018, 18, 54. [CrossRef] [PubMed]

295. Dias, A.; Nunez Gil, I.J.; Santoro, F.; Madias, J.E.; Pelliccia, F.; Brunetti, N.D.; Salmoirago-Blotcher, E.; Sharkey, S.W.; Eitel, I.; Akashi, Y.J.; et al. Takotsubo syndrome: State-of-the-art review by an expert panel-Part 1. Cardiovasc. Revasc. Med. 2019, 20, 70-79. [CrossRef]

296. Paur, H.; Wright, P.T.; Sikkel, M.B.; Tranter, M.H.; Mansfield, C.; O'Gara, P.; Stuckey, D.J.; Nikolaev, V.O.; Diakonov, I.; Pannell, L.; et al. High levels of circulating epinephrine trigger apical cardiodepression in a beta2-adrenergic receptor/Gi-dependent manner: A new model of Takotsubo cardiomyopathy. Circulation 2012, 126, 697-706. [CrossRef] [PubMed]

297. Lyon, A.R.; Rees, P.S.; Prasad, S.; Poole-Wilson, P.A.; Harding, S.E. Stress (Takotsubo) cardiomyopathy-A novel pathophysiological hypothesis to explain catecholamine-induced acute myocardial stunning. Nat. Clin. Pract. Cardiovasc. Med. 2008, 5, 22-29. [CrossRef] [PubMed] 
298. Gilbert, E.M.; Eiswirth, C.C.; Mealey, P.C.; Larrabee, P.; Herrick, C.M.; Bristow, M.R. Beta-adrenergic supersensitivity of the transplanted human heart is presynaptic in origin. Circulation 1989, 79, 344-349. [CrossRef] [PubMed]

299. Yusuf, S.; Theodoropoulos, S.; Mathias, C.J.; Dhalla, N.; Wittes, J.; Mitchell, A.; Yacoub, M. Increased sensitivity of the denervated transplanted human heart to isoprenaline both before and after beta-adrenergic blockade. Circulation 1987, 75, 696-704. [CrossRef] [PubMed]

300. Boucher, M.; Nim, S.; de Montigny, C.; Rousseau, G. Alterations of beta-adrenoceptor responsiveness in postischemic myocardium after $72 \mathrm{~h}$ of reperfusion. Eur. J. Pharmacol. 2004, 495, 185-191. [CrossRef] [PubMed]

301. Anthonio, R.L.; Brodde, O.E.; van Veldhuisen, D.J.; Scholtens, E.; Crijns, H.J.; van Gilst, W.H. Beta-adrenoceptor density in chronic infarcted myocardium: A subtype specific decrease of beta1-adrenoceptor density. Int. J. Cardiol. 2000, 72, 137-141. [CrossRef]

302. Brinks, H.; Boucher, M.; Gao, E.; Chuprun, J.K.; Pesant, S.; Raake, P.W.; Huang, Z.M.; Wang, X.; Qiu, G.; Gumpert, A.; et al. Level of $\mathrm{G}$ protein-coupled receptor kinase-2 determines myocardial ischemia/reperfusion injury via pro- and anti-apoptotic mechanisms. Circ. Res. 2010, 107, 1140-1149. [CrossRef] [PubMed]

303. See Hoe, L.E.; Schilling, J.M.; Busija, A.R.; Haushalter, K.J.; Ozberk, V.; Keshwani, M.M.; Roth, D.M.; Toit, E.D.; Headrick, J.P.; Patel, H.H.; et al. Chronic beta1-adrenoceptor blockade impairs ischaemic tolerance and preconditioning in murine myocardium. Eur. J. Pharmacol. 2016, 789, 1-7. [CrossRef] [PubMed]

304. Park, H.; Otani, H.; Oishi, C.; Fujikawa, M.; Yamashita, K.; Okazaki, T.; Sato, D.; Ueyama, T.; Iwasaka, J.; Yamamoto, Y.; et al. Efficacy of intracoronary administration of a short-acting beta-blocker landiolol during reperfusion in pigs. Int. J. Cardiol. 2011, 146, 347-353. [CrossRef]

305. Spear, J.F.; Prabu, S.K.; Galati, D.; Raza, H.; Anandatheerthavarada, H.K.; Avadhani, N.G. beta1-Adrenoreceptor activation contributes to ischemia-reperfusion damage as well as playing a role in ischemic preconditioning. Am. J. Physiol. Heart Circ. Physiol. 2007, 292, H2459-H2466. [CrossRef]

306. Salie, R.; Moolman, J.A.; Lochner, A. The role of beta-adrenergic receptors in the cardioprotective effects of beta-preconditioning (betaPC). Cardiovasc. Drugs Ther. 2011, 25, 31-46. [CrossRef]

307. Lochner, A.; Genade, S.; Tromp, E.; Podzuweit, T.; Moolman, J.A. Ischemic preconditioning and the beta-adrenergic signal transduction pathway. Circulation 1999, 100, 958-966. [CrossRef] [PubMed]

308. See Hoe, L.E.; Foster, S.R.; Wendt, L.; Patel, H.H.; Headrick, J.P.; Peart, J.N. Regulation of the beta-Adrenergic Receptor Signaling Pathway in Sustained Ligand-Activated Preconditioning. J. Pharmacol. Exp. Ther. 2019, 369, 37-46. [CrossRef] [PubMed]

309. Tong, H.; Bernstein, D.; Murphy, E.; Steenbergen, C. The role of beta-adrenergic receptor signaling in cardioprotection. FASEB J. 2005, 19, 983-985. [CrossRef] [PubMed]

310. Xiao, R.P. Cell logic for dual coupling of a single class of receptors to G(s) and G(i) proteins. Circ. Res. 2000, 87, 635-637. [CrossRef] [PubMed]

311. Peart, J.N.; Gross, G.J. Chronic exposure to morphine produces a marked cardioprotective phenotype in aged mouse hearts. Exp. Gerontol. 2004, 39, 1021-1026. [CrossRef] [PubMed]

312. See Hoe, L.; Zemljic-Harpf, A.; Schilling, J.M.; Finley, C.; Kellerhals, S.E.; Roth, D.M.; Peart, J.N.; Patel, H.H.; Headrick, J.P. Opioid-mediated sustained ligand-activated preconditioning induces cardiac protection in type II diabetes mellitus. FASEB J. 2013, 27, 1169.

313. O'Connell, T.D.; Jensen, B.C.; Baker, A.J.; Simpson, P.C. Cardiac alpha1-adrenergic receptors: Novel aspects of expression, signaling mechanisms, physiologic function, and clinical importance. Pharmacol. Rev. 2014, 66, 308-333. [CrossRef]

314. Laks, M.M.; Morady, F.; Swan, H.J. Myocardial hypertrophy produced by chronic infusion of subhypertensive doses of norepinephrine in the dog. Chest 1973, 64, 75-78. [CrossRef]

315. Vecchione, C.; Fratta, L.; Rizzoni, D.; Notte, A.; Poulet, R.; Porteri, E.; Frati, G.; Guelfi, D.; Trimarco, V.; Mulvany, M.J.; et al. Cardiovascular influences of alpha1b-adrenergic receptor defect in mice. Circulation 2002, 105, 1700-1707. [CrossRef]

316. Tejero-Taldo, M.I.; Gursoy, E.; Zhao, T.C.; Kukreja, R.C. Alpha-adrenergic receptor stimulation produces late preconditioning through inducible nitric oxide synthase in mouse heart. J. Mol. Cell. Cardiol. 2002, 34, 185-195. [CrossRef]

317. Meng, X.; Brown, J.M.; Ao, L.; Banerjee, A.; Harken, A.H. Norepinephrine induces cardiac heat shock protein 70 and delayed cardioprotection in the rat through alpha 1 adrenoceptors. Cardiovasc. Res. 1996, 32, 374-383. [CrossRef] 
318. Baghelai, K.; Graham, L.J.; Wechsler, A.S.; Jakoi, E.R. Delayed myocardial preconditioning by alpha1-adrenoceptors involves inhibition of apoptosis. J. Thorac. Cardiovasc. Surg. 1999, 117, 980-986. [CrossRef]

319. Zhu, H.; McElwee-Witmer, S.; Perrone, M.; Clark, K.L.; Zilberstein, A. Phenylephrine protects neonatal rat cardiomyocytes from hypoxia and serum deprivation-induced apoptosis. Cell Death Differ. 2000, 7, 773-784. [CrossRef]

320. O'Connell, T.D.; Swigart, P.M.; Rodrigo, M.C.; Ishizaka, S.; Joho, S.; Turnbull, L.; Tecott, L.H.; Baker, A.J.; Foster, E.; Grossman, W.; et al. Alpha1-adrenergic receptors prevent a maladaptive cardiac response to pressure overload. J. Clin. Investig. 2006, 116, 1005-1015. [CrossRef]

321. Tonnarini, G.; Parlapiano, C.; Cavallotti, D.; Tego, A.; Curione, M.; Giancaspro, G.; Vincentelli, G.M.; Leone, S.; Cavallotti, C. Dopamine receptor subtypes in the human coronary vessels of healthy subjects. J. Recept. Signal Transduct. Res. 2011, 31, 33-38. [CrossRef]

322. Cavallotti, C.; Mancone, M.; Bruzzone, P.; Sabbatini, M.; Mignini, F. Dopamine receptor subtypes in the native human heart. Heart Vessel. 2010, 25, 432-437. [CrossRef]

323. Li, H.; Shi, S.; Sun, Y.H.; Zhao, Y.J.; Li, Q.F.; Li, H.Z.; Wang, R.; Xu, C.Q. Dopamine D2 receptor stimulation inhibits angiotensin II-induced hypertrophy in cultured neonatal rat ventricular myocytes. Clin. Exp. Pharmacol. Physiol. 2009, 36, 312-318. [CrossRef]

324. Richmond, M.E.; Easterwood, R.; Singh, R.K.; Gilmore, L.; Beddows, K.; Zuckerman, W.A.; McFeely, E.D.; Chen, J.M.; Addonizio, L.J. Low-Dose Donor Dopamine Is Associated with a Decreased Risk of Right Heart Failure in Pediatric Heart Transplant Recipients. Transplantation 2016, 100, 2729-2734. [CrossRef]

325. Benck, U.; Hoeger, S.; Brinkkoetter, P.T.; Gottmann, U.; Doenmez, D.; Boesebeck, D.; Lauchart, W.; Gummert, J.; Karck, M.; Lehmkuhl, H.B.; et al. Effects of donor pre-treatment with dopamine on survival after heart transplantation: A cohort study of heart transplant recipients nested in a randomized controlled multicenter trial. J. Am. Coll. Cardiol. 2011, 58, 1768-1777. [CrossRef]

326. Roy, N.; Friehs, I.; Cowan, D.B.; Zurakowski, D.; McGowan, F.X.; del Nido, P.J. Dopamine induces postischemic cardiomyocyte apoptosis in vivo: An effect ameliorated by propofol. Ann. Thorac. Surg. 2006, 82, 2192-2199. [CrossRef]

327. Port, J.D.; Gilbert, E.M.; Larrabee, P.; Mealey, P.; Volkman, K.; Ginsburg, R.; Hershberger, R.E.; Murray, J.; Bristow, M.R. Neurotransmitter depletion compromises the ability of indirect-acting amines to provide inotropic support in the failing human heart. Circulation 1990, 81, 929-938. [CrossRef]

328. Lazou, A.; Markou, T.; Zioga, M.; Vasara, E.; Efstathiou, A.; Gaitanaki, C. Dopamine mimics the cardioprotective effect of ischemic preconditioning via activation of alpha1-adrenoceptors in the isolated rat heart. Physiol. Res. 2006, 55, 1-8.

329. Gupta, V.; Goyal, R.; Sharma, P.L. Preconditioning offers cardioprotection in hyperlipidemic rat hearts: Possible role of Dopamine (D2) signaling. BMC Cardiovasc. Disord. 2015, 15, 77. [CrossRef]

330. Wei, C.; Gao, J.; Li, M.; Li, H.; Wang, Y.; Li, H.; Xu, C. Dopamine D2 receptors contribute to cardioprotection of ischemic post-conditioning via activating autophagy in isolated rat hearts. Int. J. Cardiol. 2016, 203, 837-839. [CrossRef]

331. Gao, J.; Guo, J.; Li, H.; Bai, S.; Li, H.; Wu, B.; Wang, L.; Xi, Y.; Tian, Y.; Yang, G.; et al. Involvement of dopamine $\mathrm{D} 2$ receptors activation in ischemic post-conditioning-induced cardioprotection through promoting PKC-epsilon particulate translocation in isolated rat hearts. Mol. Cell. Biochem. 2013, 379, 267-276. [CrossRef]

332. Li, H.; Wei, C.; Gao, J.; Bai, S.; Li, H.; Zhao, Y.; Li, H.; Han, L.; Tian, Y.; Yang, G.; et al. Mediation of dopamine D2 receptors activation in post-conditioning-attenuated cardiomyocyte apoptosis. Exp. Cell Res. 2014, 323, 118-130. [CrossRef]

333. Vettel, C.; Hottenrott, M.C.; Spindler, R.; Benck, U.; Schnuelle, P.; Tsagogiorgas, C.; Kramer, B.K.; Hoeger, S.; El-Armouche, A.; Wieland, T.; et al. Dopamine and lipophilic derivates protect cardiomyocytes against cold preservation injury. J. Pharmacol. Exp. Ther. 2014, 348, 77-85. [CrossRef]

334. Spindler, R.S.; Schnuelle, P.; Nickels, L.; Jarczyk, J.; Waldherr, R.; Theisinger, S.; Theisinger, B.; Klotz, S.; Tsagogiorgas, C.; Gottmann, U.; et al. N-Octanoyl Dopamine for Donor Treatment in a Brain-death Model of Kidney and Heart Transplantation. Transplantation 2015, 99, 935-941. [CrossRef]

335. Li, S.; Korkmaz-Icoz, S.; Radovits, T.; Ruppert, M.; Spindler, R.; Loganathan, S.; Hegedus, P.; Brlecic, P.; Theisinger, B.; Theisinger, S.; et al. Donor Preconditioning After the Onset of Brain Death with Dopamine Derivate n-Octanoyl Dopamine Improves Early Posttransplant Graft Function in the Rat. Am. J. Transplant. 2017, 17, 1802-1812. [CrossRef] 
336. Lohse, M.J.; Engelhardt, S.; Danner, S.; Bohm, M. Mechanisms of beta-adrenergic receptor desensitization: From molecular biology to heart failure. Basic Res. Cardiol. 1996, 91, 29-34. [CrossRef]

337. Lymperopoulos, A.; Rengo, G.; Koch, W.J. Adrenergic nervous system in heart failure: Pathophysiology and therapy. Circ. Res. 2013, 113, 739-753. [CrossRef]

338. Floerchinger, B.; Oberhuber, R.; Tullius, S.G. Effects of brain death on organ quality and transplant outcome. Transplant. Rev. (Orlando) 2012, 26, 54-59. [CrossRef]

339. Gordon, J.K.; McKinlay, J. Physiological changes after brain stem death and management of the heart-beating donor. BJA Educ. 2012, 12, 225-229. [CrossRef]

340. Braulio, R.; Sanches, M.D.; Teixeira Junior, A.L.; Costa, P.H.; Moreira Mda, C.; Rocha, M.A.; Andrade, S.A.; Gelape, C.L. Associated Clinical and Laboratory Markers of Donor on Allograft Function After Heart Transplant. Braz. J. Cardiovasc. Surg. 2016, 31, 89-97. [CrossRef]

341. Stoica, S.C.; Satchithananda, D.K.; White, P.A.; Parameshwar, J.; Redington, A.N.; Large, S.R. Noradrenaline use in the human donor and relationship with load-independent right ventricular contractility. Transplantation 2004, 78, 1193-1197. [CrossRef]

342. Angleitner, P.; Kaider, A.; Gokler, J.; Moayedifar, R.; Osorio-Jaramillo, E.; Zuckermann, A.; Laufer, G.; Aliabadi-Zuckermann, A. High-dose catecholamine donor support and outcomes after heart transplantation. J. Heart Lung Transplant. 2018, 37, 596-603. [CrossRef]

343. Costanzo, M.R. Don't worry, be happy with intravenous norepinephrine. J. Heart Lung Transplant. 2018, 37, 572-574. [CrossRef]

344. Nixon, J.L.; Kfoury, A.G.; Brunisholz, K.; Horne, B.D.; Myrick, C.; Miller, D.V.; Budge, D.; Bader, F.; Everitt, M.; Saidi, A.; et al. Impact of high-dose inotropic donor support on early myocardial necrosis and outcomes in cardiac transplantation. Clin. Transplant. 2012, 26, 322-327. [CrossRef]

345. Milting, H.; Scholz, C.; Arusoglu, L.; Freitag, M.; Cebulla, R.; Jaquet, K.; Korfer, R.; Lewinski, D.V.; Kassner, A.; Brodde, O.E.; et al. Selective upregulation of beta1-adrenergic receptors and dephosphorylation of troponin I in end-stage heart failure patients supported by ventricular assist devices. J. Mol. Cell. Cardiol. 2006, 41, 441-450. [CrossRef]

346. Nakahara, K.; Horimoto, H.; Nakai, Y.; Mieno, S.; Nomura, Y.; Sasaki, S. Left ventricular mechanical unloading restores Beta-2-adrenergic receptor mRNA expression and decreases susceptibility to ischemia and reperfusion in the failing heart. Eur. Surg. Res. 2003, 35, 108-114. [CrossRef]

347. Pandalai, P.K.; Bulcao, C.F.; Merrill, W.H.; Akhter, S.A. Restoration of myocardial beta-adrenergic receptor signaling after left ventricular assist device support. J. Thorac. Cardiovasc. Surg. 2006, 131, 975-980. [CrossRef]

348. Akhter, S.A.; D'Souza, K.M.; Malhotra, R.; Staron, M.L.; Valeroso, T.B.; Fedson, S.E.; Anderson, A.S.; Raman, J.; Jeevanandam, V. Reversal of impaired myocardial beta-adrenergic receptor signaling by continuous-flow left ventricular assist device support. J. Heart Lung Transplant. 2010, 29, 603-609. [CrossRef]

349. Ogletree-Hughes, M.L.; Stull, L.B.; Sweet, W.E.; Smedira, N.G.; McCarthy, P.M.; Moravec, C.S. Mechanical unloading restores beta-adrenergic responsiveness and reverses receptor downregulation in the failing human heart. Circulation 2001, 104, 881-886. [CrossRef]

350. Ji, X.F.; Shuo, W.; Yang, L.; Li, C.S. Impaired beta-adrenergic receptor signalling in post-resuscitation myocardial dysfunction. Resuscitation 2012, 83, 640-644. [CrossRef]

351. Shin, E.; Ko, K.S.; Rhee, B.D.; Han, J.; Kim, N. Different effects of prolonged beta-adrenergic stimulation on heart and cerebral artery. Integr. Med. Res. 2014, 3, 204-210. [CrossRef]

352. Chen, M.; Sato, P.Y.; Chuprun, J.K.; Peroutka, R.J.; Otis, N.J.; Ibetti, J.; Pan, S.; Sheu, S.S.; Gao, E.; Koch, W.J. Prodeath signaling of $\mathrm{G}$ protein-coupled receptor kinase 2 in cardiac myocytes after ischemic stress occurs via extracellular signal-regulated kinase-dependent heat shock protein 90-mediated mitochondrial targeting. Circ. Res. 2013, 112, 1121-1134. [CrossRef]

353. Sato, P.Y.; Chuprun, J.K.; Grisanti, L.A.; Woodall, M.C.; Brown, B.R.; Roy, R.; Traynham, C.J.; Ibetti, J.; Lucchese, A.M.; Yuan, A.; et al. Restricting mitochondrial GRK2 post-ischemia confers cardioprotection by reducing myocyte death and maintaining glucose oxidation. Sci. Signal. 2018, 11, eaau0144. [CrossRef]

354. Woodall, M.C.; Ciccarelli, M.; Woodall, B.P.; Koch, W.J. G protein-coupled receptor kinase 2: A link between myocardial contractile function and cardiac metabolism. Circ. Res. 2014, 114, 1661-1670. [CrossRef]

355. Bittner, H.B.; Chen, E.P.; Milano, C.A.; Kendall, S.W.; Jennings, R.B.; Sabiston, D.C., Jr.; Van Trigt, P. Myocardial beta-adrenergic receptor function and high-energy phosphates in brain death-Related cardiac dysfunction. Circulation 1995, 92, II472-8. [CrossRef] 
356. Pandalai, P.K.; Lyons, J.M.; Duffy, J.Y.; McLean, K.M.; Wagner, C.J.; Merrill, W.H.; Pearl, J.M.; Akhter, S.A. Role of the beta-adrenergic receptor kinase in myocardial dysfunction after brain death. J. Thorac. Cardiovasc. Surg. 2005, 130, 1183-1189. [CrossRef]

357. Wong, H.S.; Dighe, P.A.; Mezera, V.; Monternier, P.A.; Brand, M.D. Production of superoxide and hydrogen peroxide from specific mitochondrial sites under different bioenergetic conditions. J. Biol. Chem. 2017, 292, 16804-16809. [CrossRef]

358. Woo, A.Y.; Xiao, R.P. beta-Adrenergic receptor subtype signaling in heart: From bench to bedside. Acta Pharmacol. Sin. 2012, 33, 335-341. [CrossRef]

359. Wells, M.A.; See Hoe, L.E.; Bouquet, M.; Molenaar, P.; Obonyo, N.G.; McDonald, C.; James, L.; Engkilde-Pedersen, S.; Hyslop, K.; Passmore, M.; et al. Donor Brain Stem Death and Cardiac Transplantation Mediate Mitochondrial Dyscoupling and Oxidative Stress; Humana Press: New York, NY, USA, 2019.

360. Hartmann, C.; Radermacher, P.; Wepler, M.; Nussbaum, B. Non-Hemodynamic Effects of Catecholamines. Shock 2017, 48, 390-400. [CrossRef]

361. Karwi, Q.G.; Uddin, G.M.; Ho, K.L.; Lopaschuk, G.D. Loss of Metabolic Flexibility in the Failing Heart. Front. Cardiovasc. Med. 2018, 5, 68. [CrossRef]

362. Liaudet, L.; Calderari, B.; Pacher, P. Pathophysiological mechanisms of catecholamine and cocaine-mediated cardiotoxicity. Heart Fail. Rev. 2014, 19, 815-824. [CrossRef]

363. Erb, J.; Beutlhauser, T.; Feldheiser, A.; Schuster, B.; Treskatsch, S.; Grubitzsch, H.; Spies, C. Influence of levosimendan on organ dysfunction in patients with severely reduced left ventricular function undergoing cardiac surgery. J. Int. Med. Res. 2014, 42, 750-764. [CrossRef]

364. Soeding, P.F.; Crack, P.J.; Wright, C.E.; Angus, J.A.; Royse, C.F. Levosimendan preserves the contractile responsiveness of hypoxic human myocardium via mitochondrial K(ATP) channel and potential pERK 1/2 activation. Eur. J. Pharmacol. 2011, 655, 59-66. [CrossRef]

365. Parissis, J.T.; Adamopoulos, S.; Antoniades, C.; Kostakis, G.; Rigas, A.; Kyrzopoulos, S.; Iliodromitis, E.; Kremastinos, D. Effects of levosimendan on circulating pro-inflammatory cytokines and soluble apoptosis mediators in patients with decompensated advanced heart failure. Am. J. Cardiol. 2004, 93, 1309-1312. [CrossRef]

366. Beiras-Fernandez, A.; Weis, F.C.; Kur, F.; Kaczmarek, I.; Schmoeckel, M.; Weis, M.; Reichart, B. Primary graft failure and Ca2+ sensitizers after heart transplantation. Transplant. Proc. 2008, 40, 951-952. [CrossRef]

367. Affronti, A.; di Bella, I.; Carino, D.; Ragni, T. Levosimendan may improve weaning outcomes in venoarterial ECMO patients. ASAIO J. 2013, 59, 554-557. [CrossRef]

368. Sponga, S.; Ivanitskaia, E.; Potapov, E.; Krabatsch, T.; Hetzer, R.; Lehmkuhl, H. Preoperative treatment with levosimendan in candidates for mechanical circulatory support. ASAIO J. 2012, 58, 6-11. [CrossRef]

369. Gordon, A.C.; Santhakumaran, S.; Al-Beidh, F.; Orme, R.M.L.; Perkins, G.D.; Singer, M.; McAuley, D.F.; Mason, A.J.; Ward, J.K.; O'Dea, K.P.; et al. Levosimendan to Prevent Acute Organ Dysfunction in Sepsis: The LeoPARDS RCT; NIHR Journals Library: Southampton, UK, 2018.

370. Landoni, G.; Lomivorotov, V.V.; Alvaro, G.; Lobreglio, R.; Pisano, A.; Guarracino, F.; Calabro, M.G.; Grigoryev, E.V.; Likhvantsev, V.V.; Salgado-Filho, M.F.; et al. Levosimendan for Hemodynamic Support after Cardiac Surgery. N. Engl. J. Med. 2017, 376, 2021-2031. [CrossRef]

371. Mebazaa, A.; Nieminen, M.S.; Packer, M.; Cohen-Solal, A.; Kleber, F.X.; Pocock, S.J.; Thakkar, R.; Padley, R.J.; Poder, P.; Kivikko, M.; et al. Levosimendan vs dobutamine for patients with acute decompensated heart failure: The SURVIVE Randomized Trial. JAMA 2007, 297, 1883-1891. [CrossRef]

372. Mehta, R.H.; Van Diepen, S.; Meza, J.; Bokesch, P.; Leimberger, J.D.; Tourt-Uhlig, S.; Swartz, M.; Parrotta, J.; Jankowich, R.; Hay, D.; et al. Levosimendan in patients with left ventricular systolic dysfunction undergoing cardiac surgery on cardiopulmonary bypass: Rationale and study design of the Levosimendan in Patients with Left Ventricular Systolic Dysfunction Undergoing Cardiac Surgery Requiring Cardiopulmonary Bypass (LEVO-CTS) trial. Am. Heart J. 2016, 182, 62-71.

373. Jessup, M.; Greenberg, B.; Mancini, D.; Cappola, T.; Pauly, D.F.; Jaski, B.; Yaroshinsky, A.; Zsebo, K.M.; Dittrich, H.; Hajjar, R.J.; et al. Calcium Upregulation by Percutaneous Administration of Gene Therapy in Cardiac Disease (CUPID): A phase 2 trial of intracoronary gene therapy of sarcoplasmic reticulum Ca2+-ATPase in patients with advanced heart failure. Circulation 2011, 124, 304-313. [CrossRef] 
374. Greenberg, B.; Yaroshinsky, A.; Zsebo, K.M.; Butler, J.; Felker, G.M.; Voors, A.A.; Rudy, J.J.; Wagner, K.; Hajjar, R.J. Design of a phase $2 b$ trial of intracoronary administration of AAV1/SERCA2a in patients with advanced heart failure: The CUPID 2 trial (calcium up-regulation by percutaneous administration of gene therapy in cardiac disease phase 2b). JACC Heart Fail. 2014, 2, 84-92. [CrossRef]

375. Tocchetti, C.G.; Wang, W.; Froehlich, J.P.; Huke, S.; Aon, M.A.; Wilson, G.M.; Di Benedetto, G.; O’Rourke, B.; Gao, W.D.; Wink, D.A.; et al. Nitroxyl improves cellular heart function by directly enhancing cardiac sarcoplasmic reticulum Ca2+ cycling. Circ. Res. 2007, 100, 96-104. [CrossRef]

376. Sabbah, H.N.; Tocchetti, C.G.; Wang, M.; Daya, S.; Gupta, R.C.; Tunin, R.S.; Mazhari, R.; Takimoto, E.; Paolocci, N.; Cowart, D.; et al. Nitroxyl (HNO): A novel approach for the acute treatment of heart failure. Circ. Heart Fail. 2013, 6, 1250-1258. [CrossRef]

377. Shah, S.J.; Blair, J.E.; Filippatos, G.S.; Macarie, C.; Ruzyllo, W.; Korewicki, J.; Bubenek-Turconi, S.I.; Ceracchi, M.; Bianchetti, M.; Carminati, P.; et al. Effects of istaroxime on diastolic stiffness in acute heart failure syndromes: Results from the Hemodynamic, Echocardiographic, and Neurohormonal Effects of Istaroxime, a Novel Intravenous Inotropic and Lusitropic Agent: A Randomized Controlled Trial in Patients Hospitalized with Heart Failure (HORIZON-HF) trial. Am. Heart J. 2009, 157, 1035-1041.

(C) 2019 by the authors. Licensee MDPI, Basel, Switzerland. This article is an open access article distributed under the terms and conditions of the Creative Commons Attribution (CC BY) license (http://creativecommons.org/licenses/by/4.0/). 